\author{
Universidade de São Paulo \\ Instituto de Física \\ Instituto de Química \\ Instituto de Biociências \\ Faculdade de Educação
}

\title{
O tema água no ensino: a visão de pesquisadores e de professores de Química
}

\author{
Daniele Torralbo
}

Orientadora: Prof. Dra. Maria Eunice Ribeiro Marcondes

Dissertação de mestrado apresentada ao Instituto de Física, ao Instituto de Química, ao Instituto de Biociências e a Faculdade de Educação da Universidade de São Paulo, para a obtenção do título de Mestre em Ensino de Ciências.

São Paulo 


\section{Daniele Torralbo}

\section{O tema água no ensino: a visão de pesquisadores e de professores de Química}

Dissertação de mestrado apresentada ao Instituto de Física, ao Instituto de Química, ao Instituto de Biociências e a Faculdade de Educação da Universidade de São Paulo, para a obtenção do título de Mestre em Ensino de Ciências.

Orientadora: Prof. Dra. Maria Eunice Ribeiro Marcondes

Comissão Examinadora

Profa. Dra. Maria Eunice Ribeiro Marcondes (USP)

Profa. Dra. Daniela Gonçalves de Abreu (USPRP)

Profa. Dra. Maria do Carmo Galiazzi (UFRG) 
FICHA CATALOGRÁFICA

Preparada pelo Serviço de Biblioteca e Informação do Instituto de Física da Universidade de São Paulo

Torralbo, Daniele

O tema água no ensino: a visão de pesquisadores e de professores de Química - São Paulo, 2009.

Dissertação (Mestrado) - Universidade de São Paulo. Instituto de Física, Instituto de Química, Faculdade de Educação e Instituto de Biociências

Orientador: Profa. Dra. Maria Eunice Ribeiro Marcondes

Área de Concentração: Ensino de Ciências

Unitermos: 1. Ensino; 2. Química; 3. Água;

4. Educação ambiental; 5. Professor 


\section{Agradecimentos}

\section{Toda honra, poder e glória sejam dados a Jesus Cristo, meu Senhor, Salvador e Amigo Fiel.}

A minha mamãe Sonia Maria Torralbo por secar minhas lágrimas inúmeras vezes, nesta fase da minha vida. Agradeço também, o apoio, a amizade, a sabedoria, o amor, a perseverança, a alegria, a paciência e as orações. Mãe eu amo você.

A meu pai Pedro Torralbo pela compreensão.

A meu irmão Hugo Torralbo muito obrigado, pelo apoio e dedicação, meu "help desk" particular.

A Paloma minha fiel companheira.

A professora Maria Eunice Ribeiro Marcondes pela dedicação e orientação, imprescindíveis para a realização deste trabalho, pela atenção constante, e pelas inúmeras reflexões e discussões.

A professora Adelaide Faljoni Alário à sua imensa amizade e apoio, no início desta caminhada.

A amiga Simone pela amizade, colaboração, atenção e paciência. Muito obrigado pelas longas conversas ao telefone, sempre me aconselhando no que precisava.

Às amigas Miriam, Renata, Rita, Dayse, Angela, Andréia, Luciane e Nilzinha.

Aos amigos João e Fábio, e aos professores que participaram desta pesquisa. 


\section{Resumo}

Torralbo, D. O tema água no ensino: a visão de pesquisadores e de professores de Química, 2009, 141 p. Dissertação (Mestrado). Universidade de São Paulo, São Paulo, 2009.

O tema "água" tem sido considerado importante no ensino da química, pois permite ao professor problematizar situações importantes para que os alunos a interpretem, de maneira que os conceitos químicos possam auxiliar no entendimento de problemas, propiciando assim, a formação de um estudante responsável. A presente pesquisa buscou investigar como os professores de Química do Ensino Médio abordam esse tema em suas aulas, e conhecer as visões de especialistas sobre os conhecimentos relevantes que a sociedade, de maneira geral, deveria ter sobre a água, bem como o que deveria ser ensinado dessa temática na escola. Os dados foram coletados entre 6 pesquisadores em Química Ambiental QA, 6 em Química das águas QAG, 5 em Educação Ambiental EA e 8 em Ensino de Química $E Q$, e 10 professores de Química do Ensino Médio. Utilizou-se um questionário para os pesquisadores em QA, QAG e EA e outro para os EQ. Os professores foram entrevistados. A análise dos dados foi feita de acordo com os pressupostos teóricos e metodológicos da análise de conteúdo e foram construídas tramas de conhecimentos. As categorias elaboradas dizem respeito a três dimensões de análise: conhecimentos, atitudes e à abordagem do tema. Ainda procurou-se identificar com que visões sobre o ambiente a temática água deveria ser abordada. Para os pesquisadores em ensino de Química $E Q$, outras dimensões foram utilizadas em função das diferentes questões a eles propostas. Assim, as dimensões dizem respeito à importância, à abordagem e aos conhecimentos considerados importantes para o ensino. Os pesquisadores em QA, QAG, EA apontaram que a sociedade deveria ter conhecimentos sobre: saúde, usos, qualidade, vida e recurso; que este tema deveria ser objeto de estudo ou tratado com exemplificação de conceitos químicos e ainda que devam ser desenvolvidas atitudes, individuais ou coletivas sobre o tema. Os especialistas em EQ apontam a importância desse tema em termos da sustentabilidade, do recurso e da vida. Alguns indicam que o tema deve ser tratado como um tema estruturante $e$ interdisciplinar.Os dados da entrevista dos professores foram analisados procurando-se comparar suas declarações sobre os conteúdos abordados e as metodologias de ensino empregadas com as tramas de conhecimentos elaboradas com as visões dos pesquisadores. Também, a partir das entrevistas, foram construídos mapas conceituais que relacionam conteúdos e abordagens do tema.

Verificamos que a maioria dos professores trata a temática da água por meio de descrições conceituais ou apenas exemplificações. Poucos abordam a água como um objeto de estudo e, quando o fazem, se restringem, principalmente, ao tratamento e a qualidade da água. Assuntos considerados importantes pelos pesquisadores, como saúde, vida e sustentabilidade não são abordados pelos professores. De maneira geral, a água é introduzida na seqüência habitual de conteúdos ministrados, embora enfocando aspectos que consideram socialmente contextualizados.

Palavras chaves: água, ensino de química, especialistas, professores. 


\begin{abstract}
Torralbo, D.The subject of water in education: the vision of researchers and chemistry teachers, 2009, 141p. Dissertation (Master's degree). Universidade de São Paulo, São Paulo, 2009.
\end{abstract}

The subject "water" has been considered important in chemistry teaching as it allows teachers to propose problems that let the students to investigate and to interpret some situations that demand the use of chemical concepts. Such a study may provide opportunities for the students not only understand and solve the proposed problems but also to develop a critical and responsible posture. This research sought to be acquainted how the high school chemistry teachers deal with this subject in classroom, the vision of experts about the relevant knowledge that the society in general should have about water as well as what should be taught about this subject in school and. Data were collected among 6 researchers in Environmental Chemistry EC, 6 in Water Chemistry WAC, 5 in Environmental Education EE and 8 in Chemistry Teaching CT and 10 high school chemistry teachers. A questionnaire was used for EC, WAC and EE researchers and another one for CT. The teachers were interviewed. Data analysis was carried out in accordance with theoretical and methodological assumptions of syllabus analysis and threads of knowledge were built. The categories are related to three dimensions: knowledge, attitude and subject approach. Furthermore, an attempt was made to identify the environmental perspective, which the subject "water" should be approached. For researchers in Chemistry teaching, other dimensions of analysis were used because of the different issues proposed to them. Thus, these dimensions are concerned with the importance, subject approach and knowledge considered essential for teaching. Researchers in EC, WAC, and EE recommended that society should have knowledge about health, use, quality, life and resources and that this subject should be object of study or treated with exemplification of chemical concepts. They also pointed out that the teaching should contribute to develop individual and collective attitudes concerning the responsible use of water. The experts in CT pointed out the importance of this subject in terms of sustainability, resource and life. Some of them indicated that the subject should be treated as a structuring and interdisciplinary subject. The teachers' interview data were analyzed seeking to compare their declarations about the topics taught and the teaching methodologies used with the threads of knowledge created by the vision of researchers. Besides that, based on the interviews, conceptual maps were produced connecting the syllabus with the approaches to the subject. We realized that most teachers deal with the subject of -water by means of conceptual descriptions or just exemplifications. A few of them deal with water as an object of study and, when they do it, they limit themselves mainly to water treatment and quality. Subjects considered important by researchers, such as health, life and sustainability are not approached by teachers. Generally speaking, water is introduced in the customary sequence of topics to be taught, however focusing on aspects that they consider socially contextualized.

Keywords: water, chemistry teaching, researchers, teachers. 


\section{Sumário}

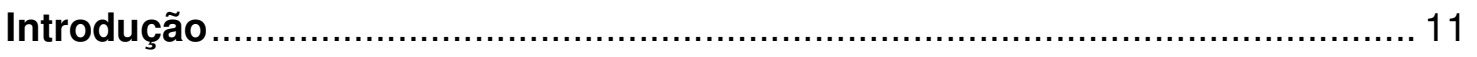

Capítulo 1. Algumas considerações sobre a água ...................................... 14

Capítulo 2. Fundamentação Teórica ......................................................... 16

2.1 A problemática da água e a educação ambiental...................................... 16

2.2 Contextualização no ensino de Ciências.................................................. 24

2.3 As relações com a ciência, tecnologia, sociedade e o tema ambiental água.... 26

2.4 A contextualização da água na transformação da realidade social ...................28

2.5 A contextualização da água como exemplificação e informações do cotidiano como meio para descrever conceitos..................................................... 31

Capítulo 3. Revisão Bibliográfica .......................................................... 33

3.1 A água no Ensino de Ciências e Química. .................................................. 33

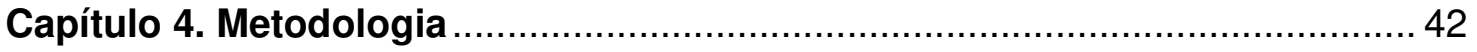

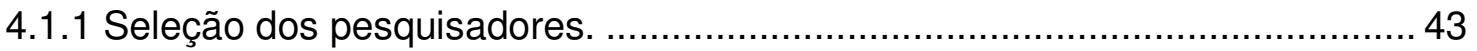

4.1.2 Coleta de dados dos pesquisadores .................................................. 44

4.1.3 Análise de dados dos pesquisadores ................................................ 45

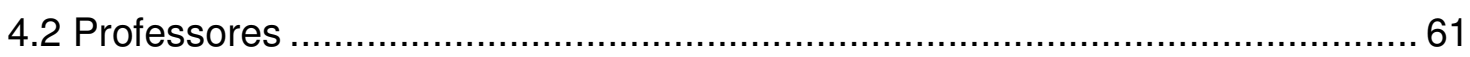

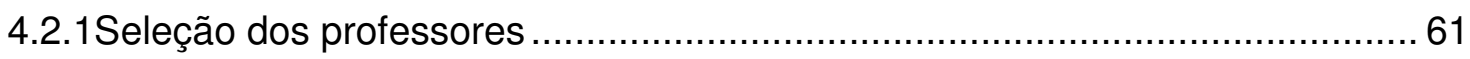

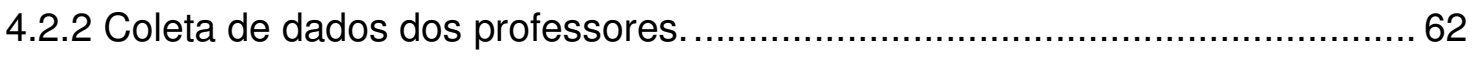

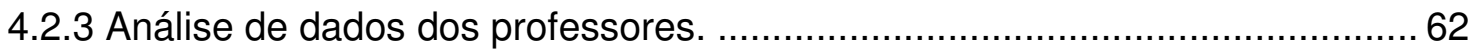

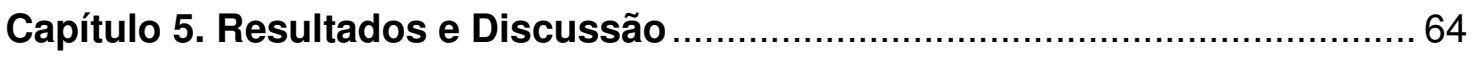

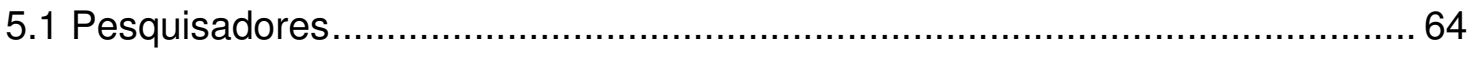

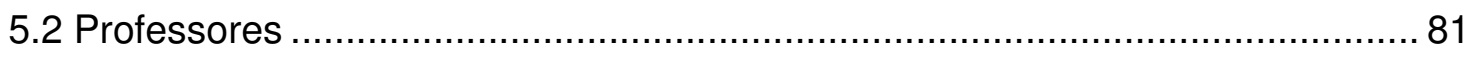

Capítulo 6. Conclusão e Considerações finais .......................................... 129

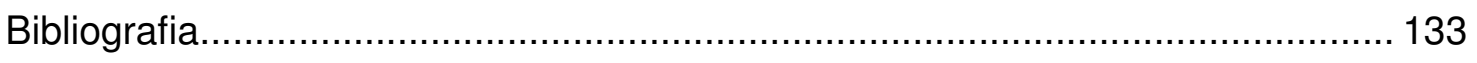

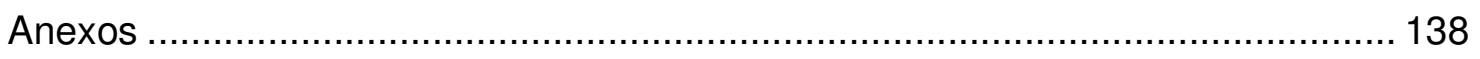




\section{Lista de figuras}

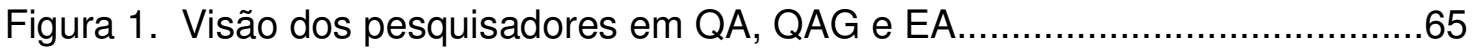

Figura 2. Visão dos pesquisadores em EQ..................................................67

Figura 3. Importância relativa dos conceitos científicos citados pelos pesquisadores

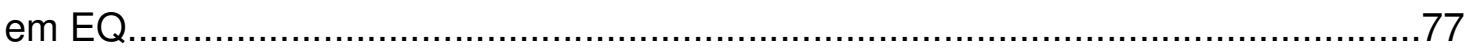

Figura 4. Importância relativa dos temas citados pelos pesquisadores em EQ.......80 Figura 5. Mapa conceitual das idéias do P1 sobre os conteúdos tratados e como os

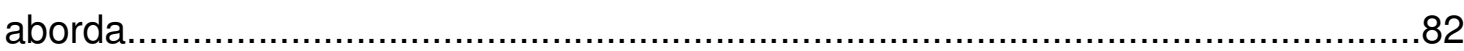

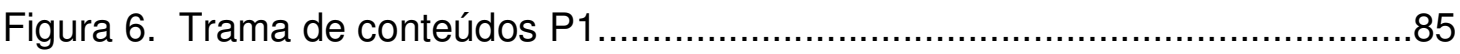

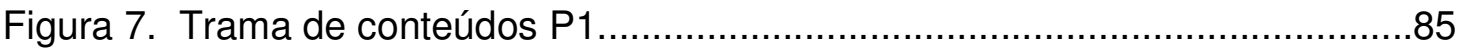

Figura 8. Mapa conceitual das idéias do P2 sobre os conteúdos tratados e como os

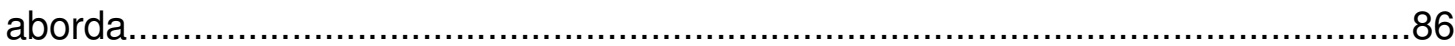

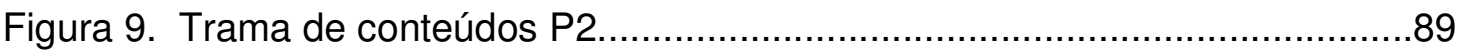

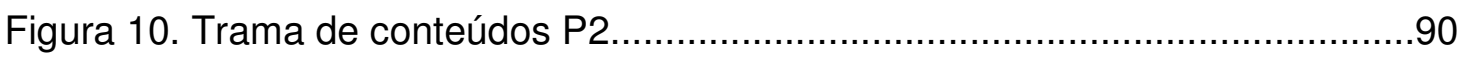

Figura 11. Mapa conceitual das idéias do P3 sobre os conteúdos tratados e como

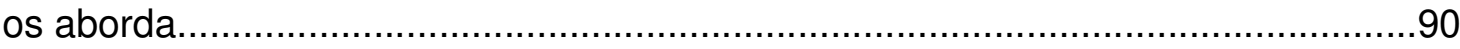

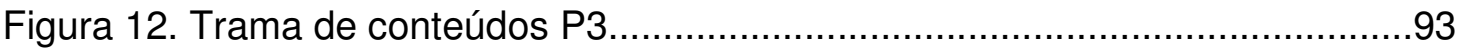

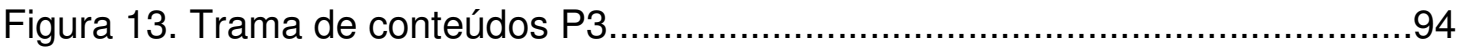

Figura 14. Mapa conceitual das idéias do P4 sobre os conteúdos tratados e como

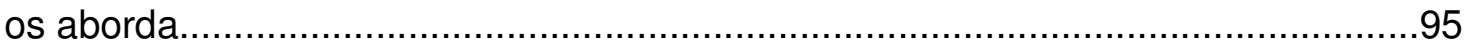

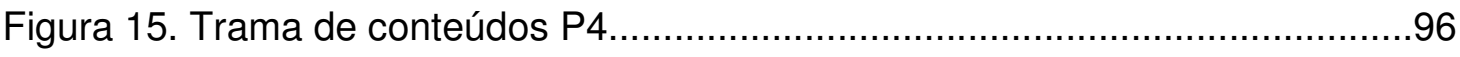

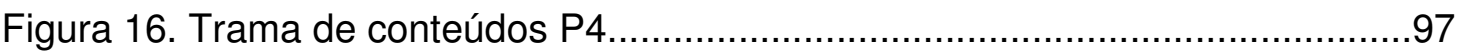

Figura 17. Mapa conceitual das idéias do P5 sobre os conteúdos tratados e como

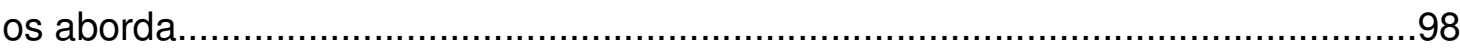

Figura 18. Trama de conteúdos P5 ...........................................................100

Figura 19. Trama de conteúdos P5..............................................................100

Figura 20. Mapa conceitual das idéias do P6 sobre os conteúdos tratados e como

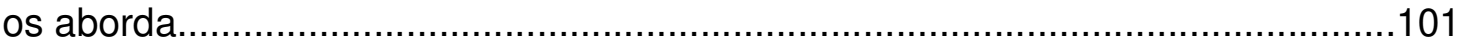

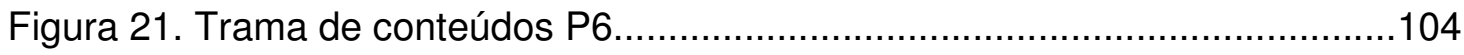

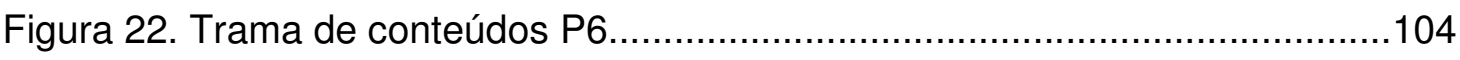


Figura 23. Mapa conceitual das idéias do P7 sobre os conteúdos tratados e como os aborda....... 105

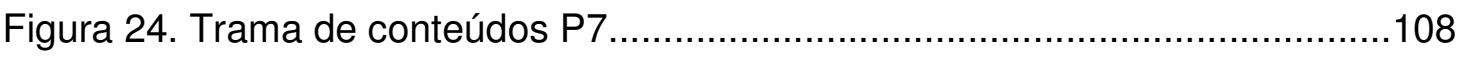

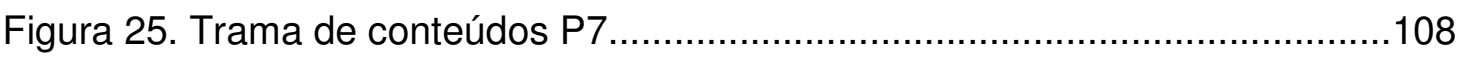

Figura 26. Mapa conceitual das idéias do P8 sobre os conteúdos tratados e como os aborda. 109

Figura 27. Trama de conteúdos P8.................................................................112

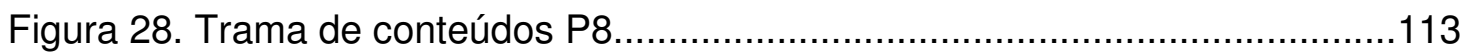

Figura 29. Mapa conceitual das idéias do P9 sobre os conteúdos tratados e como

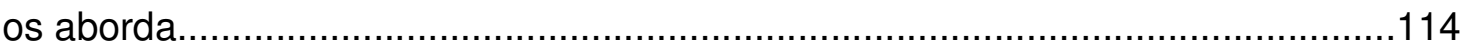

Figura 30. Trama de conteúdos P9.............................................................115

Figura 31. Trama de conteúdos P9.........................................................116

Figura 32. Mapa conceitual das idéias do P10 sobre os conteúdos tratados e como

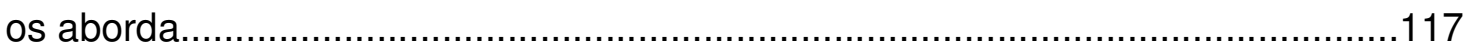

Figura 33. Trama de conteúdos dos professores P10 ........................................119

Figura 34. Trama de conteúdos dos professores P10 .....................................119

Figura 35. Trama de conteúdos dos professores e pesquisadores em QA, QAG e

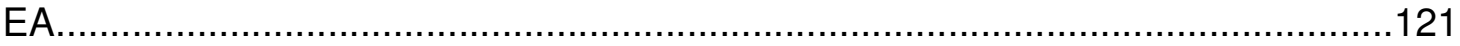

Figura 36. Trama de conteúdos dos professores e pesquisadores em EQ...........122 


\section{Lista de tabelas}

Tabela 1. Dados dos Professores..........................................................61

Tabela 2. Conceitos Científicos citados pelos pesquisadores em EQ....................75

Tabela 3. Média dos conceitos científicos citados pelos pesquisadores em

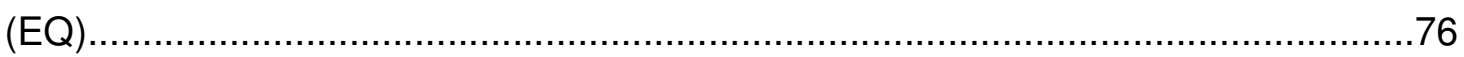

Tabela 4. Temas citados pelos pesquisadores em EQ..................................78

Tabela 5. Média dos temas citados pelos pesquisadores em EQ ..........................80

Tabela 6.Temas citados pelos professores e as respectivas séries em que são

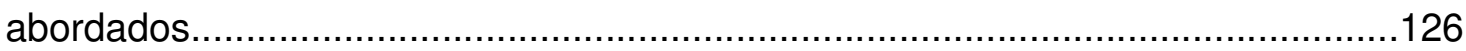

Tabela 7. Número de professores e temas citados por série..............................127 


\section{Introdução}

A incorporação de temas relacionados ao meio ambiente no ensino de Química tem sido considerada importante, pois pode contribuir para a formação da cidadania, tendo em vista a possibilidade de uma compreensão mais ampla das problemáticas ambientais. Ainda, a temática ambiental tratada em aula de química pode proporcionar uma apropriação mais significativa dos conceitos químicos.

Alguns temas ambientais têm sido introduzidos nos livros didáticos de Química, o que pode indicar que, de alguma forma, os professores dispõem de uma fonte de recursos para abordar tais temáticas em suas aulas. Entretanto, o tratamento dado nos livros é um tanto superficial, uma vez que se restringem muitas vezes a descrições de problemas (PIZZATO, 2002).

A importância de abordar o tema água no ensino da química é entendida como um recurso para realizar aproximações entre os conceitos químicos e situações do cotidiano do aluno. Através da água o professor pode problematizar, investigar e interpretar situações importantes para os alunos de maneira que os conceitos químicos possam auxiliar no entendimento e resolução de problemas, propiciando assim, a formação de um estudante crítico e responsável.

O tema água tem feito parte do ensino de química, não pelos seus aspectos sócio-ambientais, mas principalmente pelos conteúdos químicos que permite tratar, tais como soluções, reações químicas, velocidade das reações, concentração e propriedades coligativas (Silva, 2003). Geralmente, apenas aspectos relacionados à poluição das águas e ao tratamento são abordados, numa óptica de exemplificação dos conceitos ensinados.

Acreditamos assim, que a construção de práticas pedagógicas que considerem os princípios da educação em uma perspectiva sócio-ambiental deve levar em consideração diferentes dimensões como a cultural, a tecnológica, social, política, ambientais, econômicas entre outras, sendo que no ensino médio e fundamental freqüentemente isso ocorre de uma maneira superficial. Nesse enfoque, o papel do professor adquire grande importância, pois é necessário que este compreenda a relevância desse tema na escola, utilizando-o como norteador de sua prática pedagógica, em um foco sócio ambiental. 
Alguns professores de química demonstram certa dificuldade em tratar os conhecimentos químicos numa perspectiva de contextualização que valorize a reflexão e a tomada de decisões (Silva e Marcondes, 2006). Os professores, em sua prática apresentam certa dificuldade em integrar a temática ambiental da água e o conhecimento químico de modo a desenvolver conhecimentos, atitudes e comportamentos que favoreçam o meio ambiente, além de desenvolver os conceitos químicos relevantes para os estudantes do Ensino Médio. Leff (2001) relata que a problemática ambiental identificada em situações de ensino e aprendizagem está dissociada do contexto social e cultural, isto é, da realidade na qual estão inseridos professores e estudantes. Isto dificulta a percepção e compreensão dos mesmos em razão da complexidade do ambiente em que vivem.

Assim, neste trabalho, identificamos o que os especialistas das áreas de Química Ambiental, Química da Água, Educação Ambiental e Ensino de Química consideram que seja importante abordar sobre o tema água no Ensino Médio. Investigamos como alguns professores de química abordam o tema água na escola básica. A contraposição dos dados obtidos (visão dos especialistas x prática dos professores de química do Ensino Médio) é interessante e poderá fornecer subsídios para otimizar a abordagem do tema água em aulas de química e também para a produção de material didático adequado.

A hipótese inicial é a de que uma grande parte dos professores de química aborda o tema água de uma maneira superficial, apenas com o foco na motivação ou exemplificação dos conceitos científicos. Sendo assim, o que os especialistas julgam importante que as pessoas saibam sobre a água, tem sido abordado pelos professores no ensino de química? E como tem sido esta abordagem?

No capítulo 1 desta dissertação são apresentadas algumas considerações importantes sobre a água.

No capítulo 2 são apresentadas a problemática da água e a educação ambiental, a contextualização no ensino de Ciências, a contextualização e as relações com a ciência, tecnologia, sociedade e o tema ambiental água, a contextualização da água na transformação da realidade social, a contextualização da água como exemplificação e informações do cotidiano como meio para descrever conceitos. 
No capítulo 3 são apresentadas as pesquisas que relatam concepções de alunos e professores sobre o tema água, e também, mencionamos várias propostas de ensino que tratam o tema como um objeto de estudo.

No capítulo 4 são apresentadas a metodologia para a escolha de pesquisadores em Química Ambiental QA, Química das águas QAG, Educação Ambiental EA e Ensino de Química EQ e professores de Química, a coleta de dados dos pesquisadores e professores, e também, a análise de dados.

No capítulo 5 são apresentados os resultados coletados com pesquisadores e professores.

No capítulo 6 são apresentadas as considerações finais desta pesquisa. 


\section{Capítulo 1. Algumas considerações sobre a água}

As origens da água e da atmosfera estão profundamente relacionadas, pois são os dois fluídos da nossa biosfera. Tanto a água como a atmosfera evoluíram na escala de tempo geológico, sendo que o surgimento das diferentes formas de vida do nosso planeta está relacionado à composição da atmosfera.

A atmosfera primitiva da Terra de 4,6 bilhões de anos atrás foi totalmente modificada. Sendo assim, não é possível estudar a origem da água sem estudar minuciosamente a composição da atmosfera e da biosfera durante as eras geológicas. Os cientistas admitem que a Terra foi formada a partir de material interestelar e gases do espaço. A atmosfera inicial da Terra continha gases inertes, como $\mathrm{Kr}, \mathrm{Xe}, \mathrm{Ne}, \mathrm{Ar}, \mathrm{He}$ a temperatura era muito alta $\left(8000^{\circ} \mathrm{C}\right)$ portanto a água estava ausente.

Segundo Salati e Lemos(1999), a Terra sofria impactos de asteróides e meteoritos, e com estes impactos de energia seria suficiente para lançar gases para o espaço, mas a temperatura era muito alta $\left(374^{\circ} \mathrm{C}\right)$ e a água não condensava. À medida que as temperaturas baixaram, os vapores de água da atmosfera condensaram-se, formaram nuvens, as quais foram atraídas pela gravidade e caíram na forma de chuva, principalmente, na superfície da Terra. A água que escoava pela superfície da crosta provocava a erosão das rochas, cujas partículas transportadas foram se acumular e formar depósitos nas suas depressões. As rochas mais antigas, formadas em ambientes subaquáticos, datam de 3,8 bilhões de anos, indicando que, pelo menos desde então, a água na forma líquida existe na Terra, assim, a atmosfera e a hidrosfera foram formadas pelos gases expelidos pelos vulcões associados a placas tectônicas.

Os dados gerados pelo Programa Hidrológico Internacional da UNESCO, que se trata de um programa científico internacional de investigação sobre a água, gestão dos recursos hídricos, educação e capacitação, é a única amplamente baseada no programa científico do sistema das Nações Unidas nesta área, sendo assim confiável. Shiklomanov (1998) apresenta os valores gerados neste programa, sendo que o volume anual da ordem de $577.200 \mathrm{~km}^{3}$ é transformado em vapor d'água, o qual sobe à atmosfera, sendo $503.000 \mathrm{~km}^{3} /$ ano evaporados dos oceanos e $74.200 \mathrm{~km}^{3} /$ ano dos continentes. A quantidade de água que cai, na forma de 
chuva, neve e neblina é de $458.000 \mathrm{~km}^{3} /$ ano nos oceanos e de $119.000 \mathrm{~km}^{3} /$ ano nos continentes. A diferença entre as quantidades de água que evaporam e caem nos domínios dos oceanos $\left(45.000 \mathrm{~km}^{3} / \mathrm{ano}\right)$ representa a umidade que é transferida destes aos continentes. Por sua vez, a diferença entre o volume precipitado nos continentes e deles evaporado $\left(44.800 \mathrm{~km}^{3} / \mathrm{ano}\right)$ representa 0 excedente hídrico que se transforma em fluxo dos rios, alimentando a umidade do solo e os aqüíferos subterrâneos. A descarga total dos rios é da ordem de 43.000 $\mathrm{km}^{3} / \mathrm{ano}$, sendo que a contribuição dos fluxos subterrâneos a esta descarga é de aproximadamente $13.000 \mathrm{~km}^{3} / \mathrm{ano}$, garantindo a perenidade dos rios durante os períodos de estiagem. Os fluxos subterrâneos que deságuam diretamente nos oceanos são da ordem de $2.100 \mathrm{~km}^{3} /$ ano. A quantidade total de água na Terra, atualmente estimada em 1.386 bilhões de $\mathrm{km}^{3}$, tem permanecido aproximadamente constante durante os últimos 500 milhões de anos. Vale ressaltar, entretanto, que as quantidades armazenadas nos diferentes reservatórios individuais de água da Terra variaram substancialmente ao longo desse período.

A qualidade da água no nosso planeta vem se deteriorando, especialmente nas últimas décadas, problemas relacionados com a poluição da água aumentaram após a Segunda Guerra Mundial, com a industrialização. O tratamento da água é uma estratégia para remover os contaminantes. Atualmente, as estações de tratamento de água (ETA) são projetadas para fornecer água continuamente, de maneira a atender a critérios de potabilidade. A portaria $n^{\circ} 1469$ Brasil (2000) ${ }^{1}$ indica as normas e padrões de potabilidade para a água destinada ao consumo humano.

O Ministério da Saúde, em articulação com as autoridades sanitárias competentes dos Estados e Distrito Federal, exercem a fiscalização e o controle do exato cumprimento das normas e padrões previstos pela portaria.

As principais operações consistem na decantação, coagulação, filtração e desinfecção. Segundo Glynnhenry e HeinKe (1996), estas operações podem

\footnotetext{
${ }^{1}$ BRASIL. Portaria N 1469, 12 de janeiro 2000. Diário Oficial da União. Brasília, D.F, 2000.
} 
evidentemente variar dependendo da fonte de água e igualmente dos padrões a serem alcançados.

\section{Capítulo 2. Fundamentação Teórica}

\subsection{A problemática da água e a educação ambiental}

A questão ambiental relativa a água transformou-se em um dos mais sérios desafios que a sociedade tem de enfrentar em curto prazo. A consciência ambiental não surge no vazio, ela envolve uma realidade caótica deste recurso natural como: poluição, escassez, degradação, exploração desordenada, desigualdades sociais, interferência do sistema econômico e político e a ocupação desordenada do espaço ambiental.

Segundo Leff (2001), a humanidade se encontra inserida em uma rede constituída por três sistemas: a Biosfera que é o conjunto de todos os ecossistemas da Terra incluindo a espécie humana, a Sociosfera, que é um sistema de instituições sócio políticos, sócio econômicas e sócias culturais desenvolvidas pelo homem para gerar relações entre a sociedade e outros sistemas e a Tecnosfera, que é um sistema criado pelo homem e submetido ao seu domínio, envolvendo: centros industriais, redes de transporte, engenharia civil, entre outros.

Desde meados do século $\mathrm{XX}$, a consciência ambiental relacionada a água vem crescendo, e muitas sociedades estão desenvolvendo políticas públicas e leis ambientais para tentar equilibrar o crescimento econômico com a preservação deste recurso de suma importância a vida. Neste período, o mundo enfrentava uma fase de crescimento desenfreado e com uma rápida industrialização, a sociedade se dividia: de um lado pessoas mais preocupadas com o acelerado crescimento tecnológico do que com a qualidade da água, e de outro lado com pessoas que se preocupavam com o crescimento industrial indiscriminado e principalmente com a contaminação e escassez da água potável.

Na década de 1970 tornou-se evidente que a educação e conscientização ambiental são essenciais para alterar o quadro de escassez e contaminação da água potável. A organização das Nações Unidas (ONU) em 1971 organizou em Genebra um seminário internacional sobre o desenvolvimento e o meio ambiente, preparando uma conferência sobre meio ambiente que se realizaria em junho 1972, em Estocolmo. 
Em Estocolmo ficou clara a relação entre as questões ambiental e da pobreza que nas palavras da então, primeira ministra da İndia, Indira Gandhi, representa a poluição mais grave. A degradação ambiental é o resultado de dois procedimentos: a exploração desenfreada dos recursos naturais e o consumo por parte das minorias ricas, e a utilização dos recursos naturais pelos pequenos agricultores, obrigados a lançar mão de estratégias de sobrevivência que passam pelo desmatamento, destruição das florestas, esgotamento dos solos e a contaminação das águas (SACHS, 2005)

A Primeira Conferência Intergovernamental sobre Educação Ambiental, realizada de 14 a 16 de outubro de 1977 em Tbilisi na Geórgia (ex-União Soviética), teve como característica minimizar as confusões existentes sobre o que seria realmente "Educação Ambiental". A Conferência de Tbilisi definiu a natureza da Educação Ambiental, através de princípios, objetivos, características, recomendações e estratégias. Considerando que todas as pessoas deveriam gozar do direito à educação ambiental, a Conferência decidiu serem as seguintes as finalidades da Educação Ambiental (DIAS, 2000):

a) gerar a compreensão da vivência e da importância da união econômica, social, política e ambiental;

b) proporcionar a todas as pessoas a possibilidade de adquirir os conhecimentos, 0 significado de valores, o interesse ativo e as atitudes necessárias para zelar o ambiente;

Também, nesta conferência foram definidos os princípios básicos da Educação Ambiental, como seguem (DIAS, 2000):

$\left.1^{\circ}\right)$ considerar o ambiente como um conjunto, isto é, em seus aspectos: político, social, econômico, científico e tecnológico;

$2^{\circ}$ ) instituir um processo contínuo, através de todas as fases do ensino formal e não-formal;

$\left.3^{\circ}\right)$ desenvolver um enfoque interdisciplinar, aproveitando o conteúdo específico de cada disciplina, de modo que se adquira uma perspectiva global;

$4^{\circ}$ ) verificar as principais urgências ambientais, do ponto de vista local, regional, nacional e internacional, de modo que os estudantes se identifiquem com as condições ambientais de outras regiões geográficas; 
$\left.5^{\circ}\right)$ concentrar-se nos problemas ambientais atuais, tendo em conta também a perspectiva histórica;

$\left.6^{\circ}\right)$ persistir na necessidade da cooperação nacional e internacional, para prevenir e solucionar os problemas ambientais;

$7^{\circ}$ ) considerar importante, os aspectos ambientais nos planos de desenvolvimento e de crescimento do mundo;

$\left.8^{\circ}\right)$ auxiliar a descobrir os indícios e as agentes reais dos problemas ambientais;

$\left.9^{\circ}\right)$ destacar a complexidade dos problemas ambientais e, em conseqüência, a necessidade de desenvolver o senso crítico;

$\left.10^{\circ}\right)$ criar diversos ambientes educativos e uma ampla escala de métodos para comunicar e adquirir conhecimentos sobre os recursos naturais, buscando as atividades práticas e as experiências do cotidiano;

No Brasil a definição da educação ambiental enquanto processo, até então confundida com Ecologia, iniciou-se na década de 1980, em meio a uma discussão política quando alguns movimentos começaram a promover a democratização do poder, depois de alguns anos de regime militar. Sendo assim ( BRASIL, 1981, p.1073) ${ }^{2}$ :

A educação ambiental foi considerada como um de seus alicerces, devendo se voltar a todos os níveis de ensino, inclusive à educação da comunidade, a fim de capacitá-la para a participação ativa na defesa do meio ambiente.

Deve-se considerar, ainda, que após a Segunda Guerra Mundial se deu inicio a discussão e à construção do conceito de Sustentabilidade relacionado à ideia de preservação do meio ambiente. A consideração de que a qualidade da água era inesgotável começou a mudar, pois, com a escassez da qualidade do recurso natural os países desenvolvidos proprietário das maiores tecnologias e os maiores responsáveis pela deteriorização da água não poderiam continuar seu desenvolvimento desenfreado.

\footnotetext{
${ }^{2}$ BRASIL. Dispõe sobre a política nacional de meio ambiente, seus fins e mecanismos de formulação e aplicação e dá outras providências. Lei n. 6.938, 31 de agosto de 1981. Diário Oficial da República Federativado Brasil. Brasília (DF); 2 set., 1981.
} 
O conceito de desenvolvimento sustentável foi introduzido pelo relatório "Nosso Futuro Comum" em 1987. Sendo assim, a sustentabilidade começou a ser tratada de uma forma global permitindo que o homem entenda que a água deve ser utilizada de maneira responsável, não alterando as presentes condições de equilíbrio do nosso planeta.

Salati (1999) aponta que no Brasil é importante identificar os motivos que fazem com que o recurso água seja um fator limitante para que se atinja o desenvolvimento sustentável, ou seja, que a sua disponibilidade seja assegurada tanto para geração atual como para futuras e as medidas importantes que devem ser tomadas:

a- Aprofundar os estudos científicos sobre o recurso água no país;

b - Desenvolver amplo programa de educação ambiental com foco centrado na água e sua importância para a saúde e o ambiente;

c - Estabelecer estruturas que permitam um aprimoramento contínuo e constante da legislação em face de realidade da gestão da demanda e da oferta da água.

d- Melhorar as estruturas institucionais envolvidas na fiscalização da água;

e- Fazer com que os projetos que envolvem o manejo de recursos hídricos tais como a construção de represas, saneamento básico, fornecimento de água e navegação fluvial, levem em consideração suas influências e interações com outros setores do ambiente e sociedade.

f- Evitar a todo custo a contaminação das águas subterrâneas por substâncias tóxicas e metais pesados.

g- Estabelecer na formação do homem procedimentos de preservação e utilização da água;

h- Aumentar a cooperação internacional com instituições mais avançadas que as brasileiras com respeito ao conhecimento de hidrologia básica.

Passados vinte anos a Conferência de Estocolmo, com o objetivo de transformar algumas propostas em instrumentos de ação, foi realizado no Rio de Janeiro, no ano de 1992, a Conferência das Nações Unidas sobre o Meio Ambiente e Desenvolvimento, conhecida como Rio 92. A conferência foi considerada a maior assembléia internacional já realizada sobre o meio ambiente, a declaração do Rio de Janeiro sobre o Meio Ambiente e Desenvolvimento é uma carta que contém 27 
princípios e obrigações dos Estados em relação ao meio ambiente e desenvolvimento. Tal documento estabelece que os Estados têm direito soberano de aproveitar seus próprios recursos, sem causar danos ao meio ambiente de outros Estados. Finalmente, a Agenda 21, o principal registro do Rio 92, consigna o compromisso assumido pelos 179 países participantes da conferência de reorientar a educação na direção do desenvolvimento sustentável.

Essas conferências contribuem para o entendimento da problemática da água, mas não resolvem o problema, existem questões mais amplas e complexas de cada sociedade, como as forças políticas e econômicas, bem como a validade dos governos e das instituições diante das populações por elas governadas. É importante reconhecer que podemos alcançar uma melhoria significativa na administração da água, desenvolvendo discussões sobre alguns aspectos políticos, sociais e econômicos que envolvam os dilemas da gestão sustentável e do acesso a água potável.

Gondsentein e Salvador (2004) afirmam que sabemos que várias são as limitações à participação efetiva da sociedade na gestão não só da água, mas também em diversas instâncias da vida pública, e apontam as limitações ao exercício da cidadania em si mesma. A responsabilidade em relação a este recurso vital, água, está associada a um crescimento da cidadania, da capacidade de participação da população nos processos políticos, econômicos, sociais, tecnológicos e ambientais.

Levados pelos compromissos firmados na Rio-92 de modo a exercer a Constituição Brasileira, os ministérios do Meio Ambiente (MMA) e da Educação e do Desporto (MEC) elaboraram e aprovaram o PRONEA- Programa Nacional de Educação Ambiental, em 1994, tendo os seguintes objetivos(PELICIONI, 1998):

a) Preparar a escola, visando à formação de consciência, atitudes e divulgação de conhecimentos voltada para a proteção do ambiente e defesa dos recursos naturais;

b) Incorporar princípios de gestão ambiental;

c) Conscientizar a sociedade para que utilizem os recursos naturais de forma responsável; 
d) Propor aos meios de comunicação as condições apropriadas para que contribuam na formação da consciência ambiental da sociedade;

e) Mobilizar a comunidades para a implantação, ampliação de práticas de Educação Ambiental.

f) Propor o aprofundamento de aspectos conceituais e metodológicos da Educação Ambiental e desenvolver material didático;

O tratamento de temas ambientais no currículo escolar permite a inserção de conceitos científicos e atividades diversificadas que possibilitam a discussão de atitudes, valores e responsabilidades dos estudantes. No Ensino Fundamental os Parâmetros Curriculares Nacionais (Brasil, 1997) propõem a inclusão de um conjunto de conteúdos ou temas, agrupados o qual é chamado de tema transversal, onde o meio ambiente aparece como um desses temas. No Ensino Médio os Parâmetros Curriculares Nacionais (Brasil, 1999) sugerem estudos sobre a hidrosfera se dá pelo estudo das diferentes águas naturais como recurso e fonte de materiais para a sobrevivência. As soluções aquosas, tema geralmente abordado no ensino de Química, são tratadas em um contexto que envolve situações problema genuínas e não como um conteúdo isolado, favorecendo assim, o desenvolvimento de competências.

Também, temos a Proposta de ensino de Química (São Paulo, 2008) destinado aos professores e alunos do ensino médio, a qual é composta por várias situações de aprendizagem, conteúdos e temas, competências e habilidades.

Para a $2^{a}$ série do ensino médio a proposta propõe, um estudo sobre a água e o seu consumo pela sociedade. Para a $3^{\text {a }}$ série do ensino médio propõe, a hidrosfera como fonte de materiais úteis para o ser humano.

A educação ambiental depende do ambiente escolar, dos alunos e do professor. No entanto, o professor que está na sala se sente acuado, por toda demanda social e institucional, a inserir a dimensão ambiental em sua prática pedagógica. É fundamental conhecer as atitudes e informações que o professor tem em relação a problemática ambiental e identificar as idéias pedagógicas que favorecem a sua metodologia de educação ambiental. Chaves e Farias (2005) em uma pesquisa apontam que o professor tem uma compreensão crítica da educação e da educação ambiental, contudo, as situações de aprendizagem relacionadas 
com a temática ambiental acabam, ainda muitas vezes, mantendo suas bases fixadas no modelo tradicional de educação.

O conhecimento e a prática em educação ambiental compõem uma situação complexa, pois envolvem várias áreas com visões diferenciadas. Os professores carregam diferentes concepções e valores que são revelados em sua prática pedagógica. Mello e Trivellato (1999) agruparam os professores de acordo com sua prática ambiental:

a) Grupo Conservador: preocupam - se em cuidar e conservar os recursos naturais;

b) Grupo da Ecologia Social: apontam um entendimento mais global da questão ambiental, porém menos comprometido com questões políticas.

c) Grupo da Ecologia Política: apresentam uma proposta de transformação social e busca de um novo modelo de desenvolvimento.

Cada prática possui uma importância significativa no ensino. A prática conservadora é importante, pois é um momento que o professor destaca atitudes que devem se praticadas por todo cidadão como: zelo, respeito e preservação. $A$ social estimula discussões e reflexões dos alunos sobre vários temas atuais como: queimadas, reciclagem e poluição das águas a política favorece discussões que propõem transformações em suas atitudes. O método político além de propor discussões sobre temas globais e interdisciplinares, permite que o aluno entenda, questione e reflita que é necessária uma transformação política

Ballantyne e Packer (1996) relatam, em sua pesquisa visões a respeito do meio ambiente definidas a partir das respostas dadas por estudantes e professores referentes a temas ambientais:

a) Visão egocêntrica na qual o ambiente é visto como tendo valor apenas quando está a serviço do homem, que tem direito sobre ele, e explorando- o em seu benefício.

b) Visão protetora, na qual a proteção ao ambiente é considerada importante para preservação da segurança ou qualidade de vida do ser humano.

c) Visão ecocêntrica, na qual o homem é visto como inserido no ambiente, e reconhecendo um valor fundamental no mundo natural, independente de sua utilidade para o homem. 
Alguns professores e estudantes infelizmente possuem visões de exploração desenfreada em relação aos recursos naturais, esquecendo-se que muitas vezes os recursos são fundamentais à vida. Também existem preocupações quando se tratam de cuidar e reconhecer a importância do meio ambiente para sua existência.

Ainda, Lago e Pádua (1989) com relação a diferentes visões sobre o ambiente, apontam quatro correntes de pensamento no campo da ecologia:

a) Ecologia Natural: preocupa-se em descrever e entender os mecanismos naturais que regulam o funcionamento dos sistemas biológicos nos níveis de organização abordados pela ciência ecológica (individuo, população, comunidade, ecossistema, bioma e biosfera). Para tal tarefa, utiliza-se de conceitos e termos provenientes da Biologia, Química, Física e Geologia, principalmente.

b) Ecologia Social: envolve diversos aspectos das relações entre o homem e o meio ambiente, responsabilizando o modo de produção atual pela crise ambiental. Tratase de gerar uma transformação de valores em escala planetária. Possui uma abordagem multidisciplinar, agrupa preocupações e conceitos das Ciências Sociais.

c) Conservacionismo: é a luta pela conservação do ambiente natural, lutando contra as pressões destrutivas da sociedade, ajudam a contrapor as tendências destrutivas da economia industrial.

d) Ecologismo: que vem se constituindo como um projeto político de transformação social calcado em princípios ecológicos e no ideal de uma sociedade não opressiva e comunitária. A idéia central do Ecologismo é de que a resolução da atual crise ecológica não poderá ser concretizada apenas com medidas parciais de conservação ambiental, mas sim através de uma ampla mudança na economia, na cultura e na própria maneira de os homens se relacionarem entre si e com a natureza.

É importante que existam estas correntes no ensino, pois a que privilegia a visão da ecologia natural permite que o aluno entenda o funcionamento da natureza, o ensino voltado para a ecologia social possibilita o entendimento de como as pessoas atuam sobre esse funcionamento, uma visão conservacionista no ensino leva a tratar da importância de conservar e proteger o meio ambiente pois é fundamental para a sobrevivência do homem, e o ensino que se fundamenta no 
ecologismo aborda mudanças nas atitudes dos alunos em relação ao meio ambiente.

As relações sociais em torno da problemática que envolve os recursos naturais no Brasil possibilitam também a formação de um sujeito ecológico. Carvalho (2002) aponta algumas versões deste sujeito: como new age, é visto como crítico, responsável, harmônico, líder, justo e equilibrado, se preocupa com os problemas ambientais locais e mundiais que influenciam na qualidade de vida dos homens e animais, e a versão ortodoxa onde se preocupa com as questões políticas que estão inseridas na situação caótica do ambiente e sugerem caminhos seguros para enfrentá-la e transformá-la. O sujeito ecológico tem suas raízes no movimento ecologista.

Quando se pensa na formação em educação ambiental dos professores de química, ciências, física, geografia, biologia e outras áreas do conhecimento, surgem várias indagações. A formação de professores não é simplesmente uma seqüência de cursos denominados capacitações, estes encontros devem priorizar uma conversa a respeito da realidade social dos professores, seus objetivos de vida, suas frustrações, suas esperanças de transformações políticas, econômicas, tecnológicas e ambientais. Carvalho (2002) afirma que a formação de professores em educação ambiental é mais que uma capacitação buscando agregar uma nova habilidade pedagógica, é um desafio à formação de um sujeito ecológico.

\subsection{Contextualização no ensino de Ciências}

A contextualização se apresenta como um modo de ensinar conceitos científicos vinculados ao cotidiano do aluno. O objetivo fundamental desse ensino na educação básica é promover a educação científica e tecnológica dos alunos, permitindo a construção de conhecimentos necessários para tomar decisões responsáveis sobre assuntos de ciência, tecnologia sociedade e meio ambiente e atuar na solução de tais questões.

Em 1988, a proposta curricular da Coordenadoria Estadual de Normas Pedagógicas CENP órgão constitutivo da Secretária da Educação do Estado de São Paulo, apontava a contextualização como um assunto extremamente importante. A proposta determina a contextualização do cotidiano como ponto de partida para o ensino de conceitos (SÃO PAULO, 1988, p. 17): 
[...] que se tome como ponto de partida no ato de partida situações de interesse imediato do aluno, o que ele vive, conhece ou sofre influencia e que se atinjam os conhecimentos químicos historicamente elaborados, de modo que lhe permitiam analisar criticamente a aplicação destes na sociedade.

A Lei de Diretrizes e Bases da Educação Nacional de 1996, a LDBEN, destaca a importância da contextualização, e estabelece que o aluno, ao terminar o ensino médio, tenha a formação de um pensamento crítico e responsável. Portanto, esse aluno deve receber uma "educação básica com princípios tecnológicos permitindo a compreensão do significado da ciência, além do processo histórico de transformação da sociedade e da cultura" (Brasil 1996, art. 36 apud Brasil, 1999, p.18) ${ }^{3}$ ou seja, um ensino contextualizado.

As Diretrizes Curriculares Nacionais do Ensino Médio DCNEM, na resolução CEB 03/98, mencionam que a contextualização aponta a relação entre o aluno e o objeto como eixo importante na apresentação dos conhecimentos escolares. Segundo o documento, devem-se envolver áreas presentes na vida pessoal, social e cultural do cidadão. As DCNEM mostram o mundo do trabalho e o aprendizado da cidadania como áreas a serem contextualizadas no ensino (BRASIL 1998 apud BRASIL, 1999, p. 79-80) ${ }^{4}$.

Os Parâmetros Curriculares Nacionais para o Ensino Médio (PCNEM), também um documento oficial, propõem a contextualização para o ensino das disciplinas. Os PCNEM apontam que partindo do dia-a-dia, o aluno pode construir conhecimentos que permitam uma leitura critica do mundo físico e possibilitem tomar decisões baseadas em conhecimentos científicos, favorecendo o exercício da cidadania (BRASIL, 1999).

Tratando do cotidiano, os PCNEM (Brasil, 1999, p. 208) relatam:

[...] tratar, como conteúdo do aprendizado matemático, científico e tecnológico, elementos do domínio vivencial dos educandos, da

\footnotetext{
${ }^{3}$ BRASIL.Lei n $^{\circ} 9.394$, de 20 de dezembro de 1996. Estabelece as diretrizes e bases da educação Nacional. Diário Oficial da União, Brasília, DF, 20 de dez. 1996.

${ }^{4}$ BRASIL. Resolução CEB n³ de 26 de junho de 1998. Institui as Diretrizes Curriculares Nacionais para o Ensino Médio. Diário Oficial da União, Brasilia, DF, 26 jun, 1998.
} 
escola e de sua comunidade imediata (...) muitas vezes, a vivência, tomada como ponto de partida, já se abre para questões gerais [...]

Os PCNEM (Brasil, 1999, p. 242) no que se referem ao ensino da disciplina de Química, relatam:

[...] utilizando-se a vivência dos alunos e os fatos do dia-a-dia, a tradição cultural, a mídia e a vida escolar, busca-se construir os conhecimentos químicos que permitam refazer essas leituras de mundo, agora com fundamentação também na ciência.

Os PCN+ (Brasil, 2002), um modelo de desdobramento dos PCNEM, estenderam a discussão da contextualização no ensino de ciências. O documento traz orientações que reforçam o estudo de contexto como ponto de partida para a articulação entre os conhecimentos das disciplinas de cada uma das áreas. $\mathrm{O}$ PCN+, na área da Química, ressalta que as escolhas do que deve ser ensinado aos alunos, obrigatoriamente, passam pela seleção de conteúdos e temas importantes que favoreçam a compreensão do meio ambiente, social, político e econômico.

Estes documentos relatam a importância da contextualização no ensino de Ciências. Desde as DCNEM, essa discussão vem se desenvolvendo e contribuindo de maneira mais significativa com o ensino de Química no Brasil.

\subsection{As relações com a ciência, tecnologia, sociedade e o tema ambiental água.}

A partir de meados do século XX, nos países capitalistas, foi crescendo o sentimento de que o desenvolvimento científico, tecnológico e econômico não estavam se preocupando com a qualidade de vida das pessoas. Auler e Bazzo (2001) relatam que, após uma euforia com os resultados do avanço científico e tecnológico, nas décadas de 1960 e 1970, a desenfreada degradação ambiental veiculada ao desenvolvimento científico e tecnológico fez com que a ciência e a tecnologia (C\&T) se tornassem um assunto e preocupante para a sociedade, sendo assim, (C\&T) passaram a ser um tema de debate político, e nesse contexto surge o denominado movimento (CTS).

Considerando que esse movimento também pode incorporar uma perspectiva de reflexão sobre impactos ambientais, Angotti e Auth (2001) relatam que passou-se a denominá-lo (CTSA) quando se estuda as relações CTS e os problemas ambientais. 
As situações de ensino e aprendizagem baseadas na discussão do tema social e ambiental água podem facilitar o desenvolvimento de atitudes responsáveis indispensáveis a sociedade moderna. A discussão de problemas que contemplem as relações CTSA permite que o aluno compreenda os recursos naturais, as tecnologias, bem como suas conseqüências na sociedade (FONTES e SILVA, 2004).

Auler (2002) destaca que a inclusão de temas sociais é recomendada pela literatura, aspecto justificado pelo fato destes permitirem relações entre os aspectos da Ciência-Tecnologia- Sociedade, propiciando condições para o desenvolvimento de atitudes de tomada de decisão por parte dos alunos.

Também, Cachapuz (1999) situa como uma nova orientação, para a Educação em Ciências, o que denomina de "Ensino de Ciências na Pós-Mudança Conceitual. Esta, nova orientação segundo ele, não se limita à construção de conceitos, o ponto de partida para a aprendizagem deve ser "situações-problemas", de preferência relativas a assuntos reais. O surgimento desta orientação, em termos de organização curricular, aponta para uma educação em Ciências que valoriza as relações Ciência/Tecnologia/Sociedade/Ambiente (CTSA).

A água é um tema social relevante e está inserida nesta problemática da degradação ambiental, portanto este recurso natural favorece uma nova orientação que evidencia inter-relações com a ciência, tecnologia e sociedade, propiciando assim, condições para o desenvolvimento de atitudes responsáveis por parte dos alunos.

Vasconcellos e Santos (2007) em sua pesquisa analisaram a abordagem de um tema CTSA em aulas de química, a análise dos dados demonstraram que os alunos identificaram várias questões socioambientais que antes não eram contempladas e que as discussões puderam refletir sobre as inter-relações (CTSA). Também encontraram algumas limitações como a escassez de material didático para a abordagem de tema (CTSA) e a falta de cooperação dos professores de outras disciplinas que não se envolveram nas atividades.

Podemos destacar um modelo metodológico sugerido por Aikenhead (1994), que propõem que a situação problema deve partir de um tema social que tenha relação direta com conhecimentos tecnológicos e científicos. Neste modelo, o 
conhecimento científico é definido em função do tema e da tecnologia, uma vez entendido os conhecimentos científicos pertinentes a questão social e ao conhecimento tecnológico, retorna-se a tecnologia, agora com o conhecimento cientifico colaborando para o entendimento dos aspectos tecnológicos. Ao final, chega-se outra vez a questão social, porém esse retorno, segundo o autor, deve estar fundamentado em conhecimentos científicos e tecnológicos, para enfim, aceitar a tomada de decisão sobre a questão social.

O ensino da temática da água pode ser feito considerando esta abordagem, pois a mesma tem o enfoque no estudo de aspectos sociais. A contextualização é o principio fundamental do ensino, o que significa um entendimento mais profundo do que uma simples exemplificação de conceitos por meio da água. O ponto de partida do ensino é a água na sociedade recorrendo-se a conceitos científicos e tecnológicos para compreender a situação da problemática deste recurso natural e vital. Essa abordagem permite uma nova visão para analisar e criticar a situação da água a partir do conhecimento adquirido nas relações (C\&T).

Segundo Acevedo (1996), as estratégias para desenvolver um ensino com essa orientação devem ser distintas em relação ao ensino tradicional caracterizado pela transmissão cultural. Então, desta maneira a importância de ensinar a resolver a problemática da água, confrontar opiniões, analisar criticamente os argumentos, saber formular questões sobre a política e a cidadania, o professor deve passar a questionar os alunos, elaborando projetos sobre este recurso natural, realizar trabalhos de campo como uma visita a estação de tratamento.

Tais estratégias necessárias para a realização da perspectiva CTS acabam por vezes encontrando resistências na pratica do professor. Auler e Delizoicov (2006) relatam que os professores de ciências apresentam passividade diante do desenvolvimento cientifico e tecnológico e necessitam superar a visão salvacionista que atribuem a ciência e a tecnologia.

\subsection{A contextualização da água na transformação da realidade social}

A contextualização da água pode ser, também, um instrumento que favoreça ao aluno a capacidade de tomada de decisão frente a problemática deste recurso natural, e a busca de soluções para o mesmo. Freire (1993) relata que quanto mais os homens assumam uma postura ativa na investigação de temas de seu interesse, 
tanto mais aprofundam a sua tomada de consciência em torno da realidade. Também, Freire (2002) aponta que é muito importante a compreensão da realidade social, e conseqüentemente, a sua transformação acontece por meio de codificações e decodificações da realidade concreta do educando.

A água faz parte do cotidiano e gera uma situação com constantes indagações, discussões e questionamentos dos conhecimentos e da realidade caótica deste recurso, sendo assim, é um caminho para o estudante intervir, compreender e criticar esta questão ambiental.

O ensino na perspectiva da transformação social parte dos saberes práticos do aluno, o saber do senso comum e o saber popular sobre o recurso água, porem sem ficar preso a eles. Freire propôs um método próprio de ensinar, mundialmente conhecido e reconhecido, no qual são defendidas a politização e dialogicidade do ato educativo. A aprendizagem sob a perspectiva político pedagógica do método de Freire (2002) envolve determinadas etapas:

- Investigação temática: pesquisa do universo vocabular e do modo de vida das pessoas da localidade (Estudo da Realidade).

Para tal, a coleta de dados não pode ser tradicional, deve procurar investigar como o estudante convive com a água.

-Tematização/codificação: O autor aponta a importância da escolha de palavras geradoras relacionadas ao tema gerador que permitam, a análise dos significados sociais.

Assim sendo, as palavras geradoras como: qualidade, vida, recurso, saúde, uso e tratamento, ligados diretamente ao tema gerador água, permitem uma abordagem interdisciplinar.

-Problematização: fase de problematizar, propor questões a respeito dos conhecimentos que integram o tema gerador e principalmente, questões sociais relacionadas a ele. A água envolve as questões sociais como: poluição e escassez da qualidade, relacionadas a este recurso vital.

No enfoque educativo baseado na contextualização como entendimento da realidade social, os conteúdos e conceitos deixam de ter importância em si mesmos, e passam a serem percebidos e discutidos em função do tema gerador água. 
Delizoicov et. al; (2002) relata que os temas geradores têm como princípios básicos: uma visão abrangente da realidade, ruptura com o conhecimento no nível comum, postura critica do educador.

O tema água atua como um objeto de estudo que envolve o praticar e o pensar, partindo de um estudo da realidade em que abrange uma rede complexa de situação singular, social e histórica, assim como uma rede de semelhanças que permite a discussão, a interpretação e a reprodução da realidade.

É muito importante abordar os conceitos científicos, tecnologias e as atitudes fundamentadas no tema gerador água, pois o mesmo está presente no cotidiano dos alunos permitindo uma participação mais significativa e dinâmica no processo de ensino e aprendizagem, sendo que este tema gerador atua como facilitador do processo, por ser um tema de fundamental importância para a sobrevivência de todo ser vivo.

Kruger e Lopes (1997) apontam que não existe criação de temas geradores, eles já existem no cotidiano das pessoas e é importante que os alunos sejam estimulados a perceber as relações e implicações. Conseqüentemente, a problemática da água como tema gerador, propicia discussões e questionamentos do conhecimento da realidade sobre este recurso natural, criando uma abertura para conhecer, compreender e intervir nesta problemática propiciando ao aluno uma alfabetização científica.

A alfabetização pela conscientização de Freire, tem seu reflexo no ensino de Ciências na assim chamada a Alfabetização Científica e Tecnológica (ACT), um conceito que pode ser compreendido num sentido amplo como: "a capacidade de ler, compreender e expressar opinião sobre assuntos de caráter científico" (Acevedo, 2003). Considerando o tema água a (ACT) possibilita o estudante a refletir, compreender e expressar opinião como a ciência e tecnologia se relacionam com a problemática da água. Assuntos como a poluição que atingem os mananciais, a responsabilidade das indústrias na perda gradativa da qualidade da água, poderia ser abordada numa perspectiva social e crítica.

Santos e Schnetzer (1997) apontam que a perspectiva ACT objetiva levar os alunos a compreender como a ciência e a tecnologia influenciam tornando capazes 
de usar o conhecimento cientifico e tecnológico na solução de seus problemas no dia-a-dia; e a assumirem decisões com responsabilidade social.

Existem propostas para o ensino de Química que adotam a água como um tema gerador, ou seja um objeto de estudo. Kruger e Lopes (1997) relatam que escolheu o tema gerador água em sua proposta de ensino, por estar presente na realidade dos alunos, esta realidade apresenta-se para eles a partir de problemas de abastecimento, poluição das fontes e principalmente, pela sua importância para os seres vivos. Esses fatores permitem que a partir da água, seja possível desenvolver conceitos científicos de uma forma mais significativa. Os autores apontam os objetivos da sua proposta de ensino, dando ênfase ao desenvolvimento de atitudes individuais de responsabilidade em relação a preservação da água. São eles:

a) Colaborar para o desenvolvimento cognitivo dos alunos;

b) Desenvolver o interesse dos alunos pela química, com um tema do cotidiano;

c) Discutir a importância da água para a sobrevivência dos seres vivos e da responsabilidade de cada cidadão um em preservá-la;

d) Conhecer a manancial de abastecimento de água para a comunidade e suas condições;

e) Identificar os tipos de poluição hídrica e quem são os responsáveis;

f) Trabalhar interdisciplinarmente com um assunto que interesse a todos;

g) Abordar conteúdos de físico-química e química geral a partir do tema água.

A água, tratada de acordo com esta metodologia além de ter significado propiciará ao estudante: pensar, conhecer, elaborar conclusões, enfim deixar de ser um transmissor de idéias do professor e se transformar em um cidadão pensante, crítico, atuante ,criador do seu próprio conhecimento e participante transformador da problemática deste recurso.

\subsection{A contextualização da água como exemplificação e informações do cotidiano como meio para descrever conceitos.}

A água é um recurso vital, presente no nosso cotidiano. Em relação ao ensino o termo cotidiano significa ser um estudo de situações comuns ligadas ao dia-a-dia dos estudantes. O objetivo do ensino, nesta perspectiva é relacionar conhecimentos do cotidiano do aluno com os conhecimentos científicos. Pode-se 
considerar a abordagem do cotidiano como sendo um ensino de conteúdos relacionados a fenômenos e fatos do dia-a-dia com vista a aprendizagem de conceitos (DELIZOICOV et al.; 2002).

Santos e Mortimer (1999) também apresentam a questão do uso do termo contextualização, isto é, a distinção entre a contextualização no ensino e o ensino de Ciências relacionado ao cotidiano. Para esses autores, enquanto a contextualização aborda o ensino de Ciências (Química) no seu contexto social com as inter-relações econômicas, sociais, culturais etc., o ensino de Ciências (Química) do cotidiano trata dos conceitos científicos relacionados aos fenômenos do cotidiano, portanto, a abordagem da água é tratada muitas vezes como um fato do dia- a- dia e o ensino continua centrado nos conceitos científicos.

No ensino pode-se observar uma relação muito próxima entre alguns conteúdos científicos e a água. Assim, são abordados assuntos como: poluição, tratamento da água quando são tratados conteúdos como soluções, concentrações e reações. Chassot (2001) ressalta, entretanto, que o ensino que promove o estudo do cotidiano, virou uma espécie de modismo e que traz embutido o propósito de ensinar pura e simplesmente os conceitos científicos, ocorrendo um reducionismo nessa perspectiva de contextualização.

Se o objetivo do ensino é simplesmente a descrição de conteúdos e conceitos, a temática água fica em segundo plano, servindo apenas como demonstração e exemplificação para abordar conceitos químicos. Cajas (2001) relata que uma característica marcante da utilização de aspectos do cotidiano no ensino de Química é a confiança no potencial motivacional, ou seja a situação do cotidiano, quando exemplificada, serve para motivar o aluno a aprender.Muitas vezes a abordagem com o enfoque (CTSA) no ensino é considerada somente como um eixo motivador.

Lufti (1992) relata que para alguns trabalhar com o cotidiano trata-se de motivar os alunos com curiosidades, geralmente sobre uma notícia de atualidades como vazamento em navios petroleiros, vazamento em usinas nucleares, chuvasácidas, morte da vida marinha, tratamento contra câncer, etc.

De certa maneira o livro didático também contribui com a metodologia da exemplificação que ocorre com os temas ambientais pois, de acordo com Pizzato 
(2002), o conhecimento ambiental tratado nos livros didáticos ocorre de maneira informativa, não havendo questionamentos que suscitassem alguma tomada de decisão por parte dos alunos leitores da obra.

Dessa maneira, os materiais didáticos quando abordam as questões ambientais estão perdendo a oportunidade de contribuir para uma formação mais significativa do cidadão. A água é um tema presente no cotidiano do estudante, portanto este conhecimento sobre a água só pode ser entendido, ampliado ou transformado quando o estudante estabelecer a relação deste com a realidade do mundo em que ele vive. $O$ ensino de química deve ser compreendido como um caminho mais amplo do que a simples transmissão de conceitos científicos. O ensino pode contribuir para formação dos alunos através da construção de conhecimentos significativos e atitudes responsáveis para uma sociedade democrática.

Reconhecemos a importância de ensinar conceitos químicos associados ao contexto econômico, político, industrial e social. Muitas vezes a seqüência e a profundidade dos conceitos são apresentadas e discutidas de maneira simplista 0 que mantêm o ensino distante das necessidades dos alunos.

\section{Capítulo 3. Revisão Bibliográfica}

\subsection{A água no Ensino de Ciências e Química.}

$\mathrm{Na}$ revisão bibliográfica desta pesquisa, apresentamos alguns trabalhos sobre as diversas concepções que os alunos do ensino fundamental e médio, têm a respeito do tema água. Silva et. al; (2008) investigaram as concepções alternativas de estudantes da educação básica sobre a composição da água.

Os dados foram coletados por meio de questionários sobre a formação da água. A análise dos resultados mostrou que os alunos apresentam uma confusão entre os conceitos de material, substância, constituintes das substâncias, átomo, transformação química, preparação e separação de materiais. Uma possível explicação seria o não entendimento por parte dos alunos do conceito de substância e do que as substâncias são formadas, pois, os professores da educação básica ensinam a seus alunos que a água é formada por hidrogênio $e$ oxigênio, sem esclarecer os verdadeiros significados destes conceitos científicos. 
Os pesquisadores concluíram que quando o professor de ciências ou de química aborda os conceitos de matéria, material, substância, constituinte das substâncias e átomo, propicia uma melhoria na aprendizagem, por parte dos alunos, sobre a natureza da água, superando dificuldades analisadas nas concepções errôneas identificadas.

Osborne e Cosgrove (1983), em sua pesquisa, verificaram as concepções de estudantes sobre a mudança de estado da água. Os participantes, entre a faixa de 12 e 17 anos, responderam um questionário com situações do cotidiano, tendo sido que explicassem diferentes fenômenos que envolvem o ciclo da água. Uma questão sobre as bolhinhas que aparecem no aquecimento da água revelou que a maioria dos alunos justificou como sendo o oxigênio e o hidrogênio.

Outra questão para explicar como o vapor que estava sobre a tampa de uma panela se tornou líquido, os alunos explicaram que são as bolhinhas do oxigênio e hidrogênio que estão na tampa que formam o líquido; a última questão foi como uma grande quantidade de gelo após alguns minutos em temperatura ambiente começa desaparecer, a maioria justificou que a água do gelo desaparece no ar. Os pesquisadores concluíram que os alunos têm concepções sobre o ciclo da água que estão distantes do conhecimento científico, ou seja, dos conceitos como: molécula, íons, átomos, substância, pressão de vapor, variações de altitudes, variação de temperatura e energia cinética. Provavelmente, estes conceitos não estão sendo abordados pelos professores no ensino de ciências e de química.

Os alunos da graduação em Química, também apresentam dificuldades em entender os conceitos científicos e os aspectos sociais envolvidos na temática da água, uma vez que os conteúdos são divididos em disciplinas ao longo do curso, e muitas vezes, são tratados de maneira superficial. Menezes e Farias (2003) em sua pesquisa, verificaram que a realização de projetos entre a Universidade e a comunidade tem propiciado aos alunos da graduação uma aprendizagem significativa sobre a água. Os estudantes coletaram uma amostra da água do rio Itapecerica e realizaram as análises de: $\mathrm{pH}$, alcalinidade, condutividade, sólidos, cloretos, dureza total, demanda química de oxigênio, oxigênio dissolvido, coliformes totais. Os alunos avaliaram a qualidade da água do rio, de acordo com os estabelecidos pela legislação ambiental vigente. 
A análise dos resultados mostrou que os conceitos usualmente abordados de maneira superficial, passaram a ser naturalmente necessários ao andamento do projeto água, contextualizando dessa forma o conhecimento. Também ocorreu uma integração da Universidade com a comunidade, os alunos criaram uma página no site da instituição contendo o percurso do rio, os resultados das análises, 0 significado de cada um dos parâmetros medidos e a legislação brasileira em vigor relacionada aos recursos hídricos. A realização do projeto água propiciou aos alunos um estudo da realidade, e também, a necessidade de buscar conhecimento científico e social. O ensino da Química foi apresentando com base no cotidiano, permitindo assim, uma aprendizagem de conceitos e o desenvolvimento de atitudes de colaboração junto à comunidade local.

Existem várias pesquisas que relatam as dificuldades dos professores em exercício, têm de abordar o tema água através de um projeto interdisciplinar, os autores Aguiar et. al.; (2008) investigaram, as concepções dos docentes em química, física e biologia sobre as espécies químicas que poderiam ser identificadas nas amostras de água do manancial e da torneira e também, análises qualitativa.

Os dados foram coletados através de um questionário, na primeira etapa observaram que ocorrem dissensões nas respostas dos professores tanto nos aspectos biológicos como nos aspectos químicos. Para os biológos tem-se uma coerência para o item coliforme fecais, indicado nos itens sobre as substâncias presentes na água da manancial e da torneira. Porém, também aparece o item coliforme totais, isso talvez devido à falta de informação do professor de química para distinguir suas idéias quanto às características biológicas da água. Em relação aos aspectos químicos, observam-se algumas idéias comuns, consideram a presença de metais, entretanto, encontram-se itens exclusivos para a amostra da água de torneira, como flúor e sulfato de alumínio, talvez por serem substâncias empregadas no tratamento da água que sai da torneira. Porém, tais substâncias não seriam detectadas nas análises qualitativas.

Já para item gases dissolvidos, percebeu-se uma tendência de idéias para a presença de gás carbônico e gás oxigênio, porém o gás cloro não foi indicado na 
amostra de água de torneira, entretanto poderia ser detectado através de testes qualitativos.

$\mathrm{Na}$ segunda etapa realizaram experimentos sobre as etapas do tratamento de água,determinação de cloro residual e água dura, determinação de íons ferro e determinação de íons cálcio, com duas amostras, logo após,os professores citaram os temas e conceitos que poderiam ser trabalhados em sala de aula, de acordo com os experimentos. A quantidade de indicações para os conteúdos químicos foi o dobro do que as propostas de temas.

Os pesquisadores concluíram que os professores fazem uma imensa confusão dos conceitos perante a suposta composição das amostras da água do manancial e da torneira com relação às espécies que seriam detectadas nas análises qualitativas. Entretanto, mostram-se motivados a realizar atividades interdisciplinares, mas, muitas vezes, não se sentem capazes, seja pelas condições de trabalho ou falta de tempo.

Os professores de outras disciplinas também apresentam dificuldades em abordar o tema água de maneira interdisciplinar, é o que apontam Lucatto e Talamoni (2007) em sua pesquisa. Os autores investigaram as práticas pedagógicas dos professores de todas as áreas do conhecimento que atuam na terceira série do Ensino médio, o tema em estudo foi como recuperar a qualidade da água do rio Ribeirão dos Peixes localizado no município de Dois Córregos em São Paulo dados foram coletados através de entrevistas.

Os resultados mostraram que os educadores não conheciam suficientemente os problemas relativos à micro bacia hidrográfica do Ribeirão dos Peixes, e por isso abordam superficialmente o tema. Numa segunda etapa da pesquisa, foi realizada uma visita ao rio Ribeirão dos Peixes, envolvendo professores de várias disciplinas e estudantes. Cada docente deveria realizar uma atividade dentro de sua especialidade Os autores concluíram que o projeto interdisciplinar com um tema ambiental propicia a articulação e uma troca de experiências entre as áreas conhecimentos, possibilitando ao aluno e professor aprendizagem de vários conceitos e uma reflexão sobre seu cotidiano e uma possível transformação sobre ele. 
Ainda, alguns trabalhos apontam experiências e sugestões de abordagem da temática água. Silva (2003) relata, em sua pesquisa, uma seqüência de atividades desenvolvidas com alunos do Ensino Médio cuja abordagem contempla conceitos químicos, tecnologias, fatos sociais e problemas ambientais. Na primeira atividade os alunos observaram em mapas a distribuição da água no planeta e discutiram o estado sólido, liquido e gasoso, concluindo que a porcentagem de água disponível para consumo humano é muito pequena, portanto deveriam reduzir o consumo. $\mathrm{Na}$ segunda atividade a pesquisadora propôs a construção de um pluviômetro que permitiu uma coleta de dados sobre o índice pluviométrico da cidade, a pesquisa de possíveis indicadores para determinação de $\mathrm{pH}$ e um estudo sobre as medidas que vêm sendo tomadas pelas autoridades para reduzir a formação de chuva ácida. Em uma terceira atividade os alunos aqueceram um béquer com água e discutiram os conceitos de dissolução e velocidade das reações. Em uma quarta atividade os alunos trouxeram diferentes rótulos de água, e discutiram os padrões legais de potabilidade, e parâmetros como: turbidez, odor, presença de sólidos, condutividade elétrica, temperatura e calor especificam. Na última atividade os alunos construíram um painel com diferentes recortes sobre poluição hídrica, sendo discutidas as formas de poluição aquática, o tratamento da água poluída e como poluir menos.

Essa proposta revela que é possível um rompimento da sequência tradicional de conteúdos científicos e uma abordagem com enfoque CTSA.

Em sua proposta para o ensino de química, Quadros (2004) apresenta um mapa conceitual para o professor abordar o tema água em suas aulas. O mapa trata a importância da água doce e salgada para a vida, de íons, solubilidade, da tecnologia utilizada na extração do sal do mar, de ligação iônica, estrutura química da água e de ligação covalente. A agricultura é apontada como sendo a principal responsável pela escassez da qualidade da água e da vida marinha dos rios, pois lançam toneladas de agrotóxicos, sendo proposto, nessa discussão, o ensino de ligações químicas, íons e atitudes de irresponsabilidades dos agricultores. A abordagem do ciclo da água permite ao professor realizar em suas aulas alguns questionamentos como: o porquê a água evapora? Por que ela não evapora toda fazendo com que sequem o lagos, extinguindo a vida aquática?Quais fatores fazem 
com que ela volte ao estado líquido? Esses questionamentos levam ao tratamento dos conceitos ebulição, solidificação, fusão, pressão atmosférica, pressão de vapor e diagramas de fases. Também, a autora propõe que sejam abordadas a importância da água para a vida das plantas, a absorção de gás carbônico, fotossíntese, reações químicas, energia de ligação, energia nas reações, reações químicas na planta, formação de amido, celulose, proteínas e absorção de nitrogênio.

Esta proposta é muito importante para o ensino da química, pois permite que o professor trate a água como sendo vital para a vida do homem, plantas e animais. Propicia, também, trazer para a sala de aula os conceitos químicos, tecnologias e atitudes de conscientização, responsabilidade e zelo em relação à qualidade e uso da água.

Outra proposta de ensino envolvendo uma oficina temática sobre a água é apresentada pelo São Paulo (2007). A primeira atividade é um experimento que possibilita determinar à quantidade de sais dissolvidos na água do mar. Um dos principais objetivos deste experimento é de verificar que a salinidade é uma medida de quantidade de sais dissolvidos nas águas naturais, portanto, uma maneira de expressar a concentração salina. A proposta também apresenta questões como: 0 que você entende pelas expressões água doce e salgada? Como você separaria o sal da água do mar? Estas perguntas têm a finalidade de iniciar um dialogo sobre o assunto, o aluno ao procurar dar uma resposta, vai manifestar os conhecimentos que já tem, podendo ter mais interesse pelos experimentos. $O$ professor não precisa apresentar respostas corretas, pois não se trata de informar os alunos, mas sim de conhecer o que eles pensam e de direcionando interesse para o tema. Os conceitos químicos que podem ser desenvolvidos com o experimento são misturas, soluções e concentração

A segunda atividade é um experimento sobre a condutibilidade elétrica da água do mar. Um dos principais objetivos deste experimento é mostrar que a condutibilidade é uma das propriedades apresentadas pela água, que pode ser modificada pela presença de certas substancias dissolvidas. A questão apresentada é: para que a água seja condutora de eletricidade, é preciso que 
substâncias sejam dissolvidas nela. Também, podem ser abordados os conceitos: sólidos iônicos, eletrólitos, estrutura da água e solvatação de íons.

A última atividade é um experimento que envolve as etapas do tratamento da água. Um dos principais objetivos deste experimento é possibilitar discussões sobre o uso da água doce pelo homem em seu cotidiano. Algumas questões propostas são: que características a água deve possuir para que possamos bebê-la? A água que chega á sua casa foi previamente tratada nas estações de tratamento de água. Você conhece alguma das etapas desse tratamento? Como imagina que se dá esse tratamento? Os conceitos que podem ser tratados são: $\mathrm{pH}$, solubilidade, concentração, transformações químicas, acidez e alcalinidade, mistura homogênea e heterogênea, qualidade da água, critérios e legislação.

Os autores apontam que as oficinas propiciam a abordagem de vários aspectos de um dado conhecimento como a hidrosfera e permitem não apenas a construção de conhecimentos químicos pelo aluno, mas também uma visão mais global do mundo, uma vez que as atividades se correlacionam com questões sociais, políticas, ambientais e econômicas.

Kruger e Lopes (1997), em sua proposta de ensino, relatam que o tema gerador permite unificar os conteúdos de forma interdisciplinar e numa seqüência relacionada com as explicações necessárias para seu entendimento. Portanto, utilizaram a água como tema gerador, justificando pela relação com o cotidiano das pessoas e também por permitir um amplo espectro de abordagem necessária para a conscientização dos alunos sobre a importância da água.

Nessa proposta são abordados inicialmente conhecimentos referentes à estrutura da água e algumas de suas propriedades. Só, então, são abordados conhecimentos socialmente contextualizados, como a composição da água da chuva, a chuva ácida no Brasil e seus efeitos sobre o ambiente natural e a saúde. Conhecimentos químicos, como ácidos, bases, óxidos, são introduzidos para os entendimentos dos aspectos tratados. Finalmente, os autores abordam assuntos como a formação dos oceanos, o ciclo da água, água para consumo humano, padrões de potabilidade, distribuição da água no planeta, poluição das águas, tratamento do esgoto. 
Segundo os autores, esta proposta não deve ser vista como receita para aplicação direta na sala de aula, mas sim como sugestões que podem propiciar ao professor de química inovar as atividades e adaptá-las ao seu cotidiano.

$\mathrm{Na}$ proposta de ensino "Interações e Transformações Químicas para o Ensino Médio", elaborado pelo GEPEQ - Grupo de Pesquisa em Ensino de Química (2005), há um volume dedicado à hidrosfera, tendo como fio condutor a sobrevivência humana. São abordados neste livro: a origem, evolução, e poluição da hidrosfera, as propriedades da água do mar e água doce, conceitos de potabilidade, tratamento, $\mathrm{pH}$, ácidos e bases, tem o guia do professor com um mapa conceitual que mostra os conceitos abordados e suas inter-relações.

Também, deve ser mencionada a Proposta Curricular para o ensino de química do Estado de São Paulo (São Paulo, 2008). O tema água é abordado em vários momentos, sendo foco do estudo nas $2^{\underline{a}}$ e $3^{\text {a }}$ séries do ensino médio.

$\mathrm{Na} 2^{\underline{a}}$ série, o tema é a potabilidade.da água, sendo apresentados conceitos químicos como pureza, concentração de soluções, para que o aluno possa analisar a qualidade da água, de acordo com o critério brasileiro de potabilidade da água. As propriedades também são enfocadas, bem como o conceito de DBO, tendo em vista o entendimento de alguns problemas ambientais. O tratamento da água também é foco de estudo, É proposto aos professores que abordem questões referentes a atitudes e uso consciente da água e a tomadas de decisões quanto ao uso responsável.

$\mathrm{Na} 3^{\text {a }}$ série do ensino médio, o tema é retomado, tendo como objetivo o conhecimento da água como fonte de materiais, assim como de problemas ambientais causados pelo uso de materiais que são lançados na água. Conceitos como pH e equilíbrio químico, dissolução, são abordados para que o aluno possa entender as perturbações causadas no sistema água na natureza. Ainda, é abordado o tratamento de esgotos.

O objetivo da proposta é o de que o aluno tenha uma aprendizagem significativa dos conceitos químicos, entenda a importância das tecnologias para a sociedade e reflita sobre o uso consciente e responsável da água potável.

Tais materiais didáticos poderiam contribuir para o professor de Química aprofundar seus conhecimentos científicos, tecnológicos, sociais e ambientais, 
assim como estabelecer relações entre a ciência e o desenvolvimento da tecnologia, e dar subsídios para o planejamento do ensino dessa temática . No mundo atual, as transformações advindas do processo de globalização podem levar o alunado a requerer níveis superiores de reflexão, particularmente em relação ao estudo da química e à aplicação de novas tecnologias, de modo a contribuir para uma melhor qualidade de vida e preservação do recurso natural água, em conseqüência, para o verdadeiro exercício da cidadania.

As propostas de ensino podem influenciar no discurso do professor, sendo necessária a construção de materiais que possam propiciar a contextualização dos conceitos químicos e a aprendizagem significativa, apresentando várias situações de aprendizagem tendo como eixo o tema água.

O livro didático, na maioria das vezes, tem abordado o tema água através de exemplificações ou descrições conceituais, como apontam (WATANABE, 2008).

Nessa pesquisa foram analisadas várias coleções de livros didáticos de Ciências, Química, Física e Geografia. Também, foi investigado como os estudantes do curso de pedagogia e os alunos do ensino fundamental representam o ciclo da água, e quais suas visões sobre política, economia, e aspectos sociais, relativas ao tema.

A análise dos resultados dos livros didáticos mostrou que na quinta série os livros abordam ciclo hidrológico, poluição, tratamento, flutuação e pressão. O tema água está presente indiretamente na sexta série, desde que seja considerado a partir de uma discussão que tenha a vida animal e vegetal como eixo principal. Não existem discussões sobre a água na sétima série, já na oitava série, o foco de estudo sobre a água está dirigido para fenômenos físicos e químicos.

No que diz respeito ao conteúdo curricular de Física do ensino médio, a água é tratada na Hidrostática, mas não como objeto de estudo e sim como meio onde os problemas de empuxo e equilíbrio podem ser analisados. No conteúdo curricular de Química, são apresentados os diagramas de fases da água, incluindo a discussão do ponto triplo, e estende-se a discussão para as questões de umidade relativa e, eventualmente, difusão, além das questões relativas à agregação da matéria. Em outros momentos, há certamente muita discussão sobre a questão do pH, envolvendo análise dos íons presentes na água. Contudo, soluções ácidas e 
básicas, ou hidrólise e eletrólise são consideradas de forma não contextualizada, dificultando compreender que se trata da mesma água que usamos diariamente.

No tratamento observado nos livros de Biologia do ensino médio, repetem-se os mesmos aspectos observados no ensino fundamental. Os livros de Geografia abordam as bacias hidrográficas, no ensino médio, ou situações claras do uso do tema água como exemplo ou como meio para tratar outros assuntos e conceitos.

A análise dos resultados mostrou que a maioria dos alunos e professores representam o ciclo da água de maneira estática e uniforme no tempo, ou seja, é um ciclo onde a mesma quantidade de água evapora num determinado intervalo de tempo. No que diz respeito aos aspectos sociais, políticos, econômicos e ambientais, os alunos mencionam que a água é um bem que poderá acabar se algumas ações, principalmente, no campo político não forem tomadas.

\section{Capítulo 4. Metodologia}

Utilizamos nesta dissertação uma análise qualitativa devido à atividade bastante complexa do trabalho do professor quando se trata de uma temática ambiental, suas relações com a escola, com o aluno, com meio ambiente, com o conhecimento a ser ensinado, assim como a metodologia que ele adota para ensinar a água.

Bogdan e Biklen (1994) descrevem cinco características de uma pesquisa de cunho qualitativo que orientou a seqüência das ações nesta parte da pesquisa. São estas: o ambiente natural como fonte de obtenção dos dados; o cuidado com a descrição na forma de palavras; um estudo sistêmico do processo e não somente dos resultados; análise e abstrações a medida que os dados vão sendo agrupados.

A pesquisa qualitativa envolve a obtenção dos dados descritivos para análise por meio da interação do pesquisador com o contexto de estudo, destaca mais o processo que propriamente os resultados e se preocupa em retratar as expectativas do entrevistado ( BOGDAN e BIKLEN 1982 apud LUDKE e ANDRÈ, 1986) ${ }^{5}$

\footnotetext{
${ }^{5}$ BOGDAN,R.; BIKLEN,S.K. Qualitative Research for Education. Boston: Ally and Bacon, 1982
} 
Então, utilizamos alguns instrumentos característicos da pesquisa qualitativa: questionário com questões abertas, entrevista semi- estruturadas e gravações em áudio.

\subsection{Pesquisadores}

\subsubsection{Seleção dos pesquisadores.}

Assim, participaram desta primeira fase da pesquisa seis pesquisadores em Química Ambiental QA, seis pesquisadores em Química das águas QAG, cinco pesquisadores em Educação Ambiental EA e oito pesquisadores em EQ.

Um de nossos objetivos foi identificar o que os especialistas ligados a pesquisas sobre a água, consideravam importante abordar sobre o tema.

No início da pesquisa escolhemos 10 pesquisadores de cada área, somente os citados acima contribuíram com a pesquisa, o fator distância entre a pesquisadora e os especialistas dificultaram um número maior de participantes.

A escolha do grupo se baseou nas informações fornecidas pelo currículo Lattes CNPq. A seguir são apresentadas as linhas de pesquisas dos diferentes grupos de especialistas

\section{Pesquisadores de QA}

Saúde humana, poluentes tóxicos no ar e exposição.

O ciclo biogeoquímico dos elementos em águas naturais,

\section{Pesquisadores QAG}

Tratamento de água e esgoto

Desenvolvimento de projetos de sistemas de tratamento de água e efluentes.

\section{Pesquisadores de EA}

Desenvolvimento sustentável, gestão compartilhada de recursos hídricos e educação ambiental

Planejamento urbano.

\section{Pesquisadores em EQ}

Atuando principalmente na capacitação de professores e produção de material para o ensino de Química.

Ensino de química com abordagem em aspectos sociais, tecnológicos, científicos e ambientais. 


\subsubsection{Coleta de dados dos pesquisadores}

Os dados foram coletados por meio de questionários abertos, por um conjunto de questões, organizadas e sistematizadas, que procuraram captar as concepções dos pesquisadores ( Rudio, 2002). Utilizamos os questionários devido ao fator distância, que separava os especialistas da pesquisadora.

Foi elaborado um instrumento ( anexo1) para coleta de dados junto aos pesquisadores preenchido por 6 pesquisadores da área de Química Ambiental QA, 5 Educação Ambiental EA e 6 Química da água QAG. Esse instrumento contou com 5 questões, cujos objetivos estão descritos a seguir:

Questão 1: refere-se a que o pesquisador considera importante que as pessoas saibam sobre o tema água. O objetivo desta questão é o de verificar quais são os conhecimentos relacionados a este recurso natural necessário a sociedade, na visão dos vários grupos de especialistas.

Questão 2: diz respeito à importância que atribuem à abordagem do tema água no ensino de química no nível médio e é solicitada uma explicação para resposta. A intenção desta questão é a de verificar quais são os diversos conhecimentos considerados importantes no ensino pelo pesquisador.

Questão 3: refere-se as quais conhecimentos os professores de química devem possuir para abordar a problemática da água. A intenção desta questão é de verificar quais são os conhecimentos que os pesquisadores julgam importantes que o professor possua para abordar este tema em suas aulas

Questão 4: refere-se a conhecimentos, atitudes e valores que os professores poderiam abordar no ensino de química através do tema água. A intenção desta questão é a de verificar as atitudes, valores e conhecimentos que os pesquisadores julgam importantes que a escola trate de maneira que os alunos possam desenvolvê-las ou praticá-los.

Questão 5: refere-se as quais visões de ambiente os professores de química deveriam abordar no ensino através do tema água. A intenção desta questão é de conhecer as visões sobre o ambiente que os pesquisadores consideram relevante, ao abordar o tema água no ensino. 
Um outro instrumento (anexo 2) foi elaborado para coletar dados juntos dos 8 pesquisadores da área ensino de química $\mathrm{EQ}$, que dedicam a estudos sobre as relações ciência, tecnologia e sociedade.

Esse instrumento contou com 3 questões, cujos objetivos estão descritos a seguir:

Questão 1: diz respeito à importância que atribuem à abordagem de tratar no ensino médio a temática da água. O objetivo desta questão é de verificar quais são os conhecimentos relacionados a este recurso natural necessário ao estudante, na visão dos especialistas EQ.

Questão 2: é solicitado que os especialistas apontem os temas e conceitos que julgam importantes e que deveriam ser abordados na temática da água no ensino da química. Foi requerido também que apontassem o grau de importância do tratamento desses assuntos e conceitos, utilizando a escala: (1) pouco importante (2) importante e (3) muito importante. A intenção desta questão é de verificar quais são os temas e conceitos de química que os pesquisadores julgam prioritários que o professor aborde sobre a água em suas aulas.

Questão 3: é solicitado que os pesquisadores apresentem outros comentários sobre a temática da água no ensino médio que julgam importante. A intenção desta questão é possibilitar o pesquisador a contribuir com informações sobre a abordagem do tema água e que não foram solicitadas no questionário.

\subsubsection{Análise de dados dos pesquisadores}

As categorias de análise para cada questão foram elaboradas a partir das respostas dos entrevistados, exceto aquelas que dizem respeito ao pensamento ambientalista, descrito por (Lago e Pádua, 1984). As categorias que serão apresentadas nos resultados desta dissertação não são excludentes, visto que vários pesquisadores apresentam discursos que se referiram a mais de uma categoria.

A análise dos dados após a leitura das respostas, de acordo com os pressupostos teóricos e metodológicos da análise de conteúdo de (BARDIN, 1977, p.42): 
A análise de conteúdo é definida como: Um conjunto de técnicas de análise das comunicações visando obter, por procedimentos sistemáticos e objetivos de descrição do conteúdo das mensagens, indicadores (quantitativos ou não) que permitam a inferência de conhecimentos relativos às condições de produção/recepção (variáveis inferidas) destas mensagens.

O autor, portanto, propõe uma análise de conteúdo, empregando técnicas de análise, com o objetivo de determinar a presença de algumas palavras ou conceitos no texto analisado, ou seja, a identificação de elementos dentro de um texto, e a partir da análise dos dados, o estabelecimento das relações entre eles, com a finalidade de fazer inferências sobre a mensagem contida no texto, definindo assim, as categorias como uma operação de classificação de elementos constitutivos de um conjunto por diferenciação.

Analisamos as respostas dos pesquisadores QA, QAG e EA do $1^{\circ}$ questionário e encontramos palavras e conceitos, ou seja, os elementos sobre a problemática da água, sendo que estes estabelecem relações e semelhanças formando um conjunto de elementos que se difere dos outros conjuntos, então definimos uma categoria cada conjunto sendo elas: saúde, tratamento, qualidade, uso, atitudes, atitude individual, atitude da sociedade, conceitos científicos, vida e recurso, a água para exemplificar conceitos e temas, a água como objeto de estudo, a água como meio para ensinar conceitos científicos e interdisciplinaridade. Também agrupamos as respostas com semelhanças, ou seja, a aspectos relacionados à visão de meio ambiente como: visão conservadora, visão naturalista, visão social e visão ecologista, utilizaram as idéias de (LAGO e PÁDUA 1989).

Assim, foi possível se estabelecer quatro dimensões de análise: uma que diz respeito a: conhecimentos, atitudes, abordagem e visões ambientais.

Analisamos as respostas dos pesquisadores $E Q$, do $2^{\circ}$ questionário, e encontramos palavras e conceitos, ou seja, os elementos sobre como a água deve ser tratada no ensino de química, sendo que estes estabelecem relações e semelhanças formando um conjunto de elementos que se difere dos outros conjuntos, então definimos uma categoria para cada conjunto sendo elas: planejamento, cidadania, recurso, sustentabilidade, vida, conceitos científicos, temas, subordinação, interdisciplinaridade e tema estruturante. 
Assim, foi possível se estabelecer em três dimensões de análise: uma que diz respeito a importância do tema, a abordagem que foi dividida em realidade e possibilidade do professor, e o conhecimento que foi dividido em temas e conceitos científicos de acordo com o grau de importância citado pelos pesquisadores.

A seguir são apresentadas as categorias de cada dimensão que envolve os pesquisadores: QA, QAG e EA. Os pesquisadores foram identificados por siglas, compostas pela respectiva área de especialidade seguidas de uma outra letra para diferenciar cada um deles.

\section{Dimensão: conhecimentos que as pessoas deveriam ter sobre a água}

Categoria: Vida

Estabelecemos a categoria vida, pois os pesquisadores julgam importante que as pessoas e os professores conheçam que a água é essencial a vida.

Nesta categoria são apresentadas idéias que relacionam o ser vivo e sua dependência da água, como essencial para vida e que a vida depende da qualidade deste recurso. Alguns exemplos são apresentados a seguir:

QAL: “(...) A vida dos seres vivos depende da água. A qualidade da água é importante para uma vida saudável".

QAA: "(...) A água é essencial para a vida. Água potável salva vida e água contaminada matam".

EAN: “(...) O significado que a água tem para o corpo dos animais e das plantas, portanto, para a preservação da vida na Terra”.

\section{Categoria: Recurso}

Estabelecemos a categoria recurso, pois os pesquisadores julgam importante que as pessoas e os professores entendam que a água é um recurso finito.

Esta categoria engloba idéias relativas à água como um recurso limitado, esgotável e natural. Alguns exemplos são apresentados a seguir:

QAL: "(...) A água é um recurso limitado (...)”

QAP: “(...) A água é um recurso natural abundante no planeta”.

EAS: “(...) Recurso hídrico finito”.

QAP: “(...) Abundância no planeta e disponibilidade em \% da água doce e salgada”. 
QAL: “(...) Abundância e a classificação de águas: doces, salobras e salinas (...)”.

\section{Categoria: Uso}

Estabelecemos a categoria uso, pois os pesquisadores julgam importante que as pessoas e os professores se conscientizem do uso inadequado da água

Nesta categoria são abordadas as idéias sobre a utilização da água em diversos setores da sociedade, trata do uso inadequado realizado pela indústria e agricultura que leva a escassez. É necessária uma conscientização no nosso cotidiano, ou seja, qual é a quantidade de água utilizada para escovar os dentes, lavar louça e outras atividades básicas. Seguem alguns exemplos:

QAP: “(...) Utilização e reutilização. Usos na agricultura e nas indústrias (...)”.

QAGP: “(..) O importante é conhecer a importância da água, principalmente no que se refere aos seus usos".

QAGJ: “(...) Uso inadequado que leva a escassez. Utilização racional, por exemplo: quantidade de água gasta p/ escovar os dentes, lavar louça e etc."

\section{Categoria: Tratamento}

Estabelecemos a categoria tratamento, pois os pesquisadores julgam importante que as pessoas e os professores entendam a tecnologia e o custo do saneamento ambiental.

Nesta categoria, são abordadas as idéias sobre o tratamento da água e suas etapas, pois o saneamento básico é muito importante evita várias doenças que podem atingir a sociedade. Para o consumo tratamos apenas a água doce, pois, a dessalinização da água salgada é inviável no momento devido ao seu custo. È muito importante tratar o efluente, as indústrias devem ter consciência da necessidade da reutilização da água utilizada nos processos industriais e agrícolas. Seguem os exemplos:

QAP: “(...) Custo do tratamento é alto (...)".'”(...) Conhecer todas etapas do tratamento.”

QAM: “(...) Processo de tratamento de água. Conceitos relacionados, tais como: razões do tratamento; custos de tratamento e como o custo se altera se a água proveniente do manancial estiver com mais contaminantes(...)considero a questão econômica um ponto importante, pois tecnologias para a produção de água potável a partir de efluentes altamente contaminados existem, mas não economicamente viáveis para uma realidade como fornecer água para a população da cidade de São Paulo. Considero a questão econômica um ponto importante, pois tecnologias para a 
produção de água potável a partir de efluentes altamente contaminados existem, mas não economicamente viáveis para uma realidade como fornecer água para a população da cidade de São Paulo".

QAL: "(...) Tratamento das águas, processos de purificação da água natural. Lixos orgânicos e industriais (...)".

EAP: "(...) Como ocorre o tratamento da água utilizada pela indústria em diversos processos industriais".

EAN: "(..) Seria desejável o conhecimento dos principais fundamentos envolvendo os processos do tratamento da água adotados pelas empresas privadas e pelo poder público (...)".

\section{Categoria: Conceito Científico}

Elaboramos a categoria conceito científico, pois os pesquisadores relatam que o tema água propicia a abordagem de vários conceitos.

São apontados conceitos específicos como: soluções, compostos iônicos, densidade, condutibilidade elétrica, equilíbrio químico, polaridade e o ciclo da água envolvendo as transformações do estado de agregação, como a evaporação, condensação e a solidificação. Seguem os relatos:

QAR: “(...) se estivermos falando sobre "pessoas" de um modo geral, acho importante elas terem um conhecimento a respeito do papel desta substância em uma série de processos biofisicoquímicos (...)".

QAL: "(...) a molécula é polar, e os conceitos correlacionados, tais como polaridade e solubilidade. Conceitos relacionados, tais como: razões do tratamento; custos de tratamento e como o custo se altera se a água proveniente do manancial estiver com mais contaminantes (...)".

QAM: “(...) água possui um ciclo biogeoquímico e é importante conhecer como é feita a mudança entre os compartimentos. Água possui grande capacidade de dissolver compostos (sólidos líquidos e gasosos), transportar materiais e possibilitar que ocorram reações químicas no seu interior. Propriedades físicas da água (ponto de fusão, densidade, calor especifico) e conseqüências para o ambiente (...)".

QAR: “(...) equilíbrios químicos (homogêneos e heterogêneos). Equilíbrios "físicos" e suas leis (Lei de Henry, Lei de Raul, transporte de massa, transferência de fases, etc.) Reatividade de compostos orgânicos e inorgânicos.".

QAL: “(..) fatores que influenciam na concentração de oxigênio na água (difusão, fotossíntese, respiração, decomposição aeróbia...) o conceito de demanda bioquímica de oxigênio, que leva o aluno a entender porque o esgoto doméstico é capaz de matar peixes por asfixia”. 


\section{Categoria: Qualidade}

Estabelecemos a categoria qualidade, pois os pesquisadores julgam importante que as pessoas e os professores conheçam os padrões de qualidade utilizados nas empresas públicas e privadas que realizam o tratamento da água.

Esta categoria engloba as idéias de que as empresas públicas e privadas garantem a potabilidade da água, pois obedece a legislação vigente no país. È importante reconhecer que a água não vai acabar o que está se esgotando é a qualidade deste recurso vital. Seguem os exemplos a seguir:

EAP: “(...) Conhecer e entender os padrões de qualidades utilizados pela Sabesp, Cetesb e Semasa no tratamento da água potável. A água não acaba, mas, perde a qualidade através da poluição, devemos economizar e reaproveitar(...)".

QAGT: “(...) Água potável- é aquela que é limpa e transparente não contém microorganismos (...)".

QAGS: “(...) É necessário saber também que não é apenas a quantidade da água que importa, mas também sua qualidade (...)".

QAL: “(...) conhecer o Índice de Qualidade de Águas determinado no estado de São Paulo pela SABESP (...)".

EAJ: “(...) compreensão dos parâmetros utilizados para a identificação do índice de qualidade da água (...)".

QAL: “(..) Informações sobre Legislação Nacional e Mundial, por exemplo, das águas tratadas e águas potáveis (...)".

\section{Categoria: Saúde}

Estabelecemos a categoria saúde, pois os pesquisadores relatam que é importante que o professor de química conheça as doenças que são transmitidas através da água e que atingem a saúde do ser humano.

Esta categoria engloba idéias que demonstram que a falta de qualidade da água ocasiona no ser humano doenças como: verminoses, diarréia, hepatite e cólera. Seguem alguns exemplos:

EAN: "(...) deve, também, mostrar como os poluentes invadem o ciclo da água, tais como os agrotóxicos, esgoto e rejeitos industriais e os prejuízos que os mesmos causam à saúde pública (...)". 
EAP: “(...) Agrotóxicos e esgotos contaminam a água causando graves problemas a saúde pública (...)".

EAS: “(...) Entender e refletir sobre a importância da água em vários âmbitos: política, saúde, industrialização e na economia do Brasil e de outros países".

\section{Dimensão: Atitudes das pessoas em relação à água}

\section{Categoria: Atitude individual}

Estabelecemos a categoria atitude individual, pois os pesquisadores julgam importante a abordagem de atitudes individuais no ensino de química.

Esta categoria engloba idéias que no ensino devem ser enfocadas: a construção de valores, conceitos, habilidades e atitudes que possibilita o entendimento da realidade da vida e a atuação consciente e responsável de pessoas, permitindo que o aluno se coloque como protagonista em relação a escassez, poluição e o uso inconsciente deste recurso tão valioso. Alguns exemplos são apresentados a seguir:

EAP: “(...) Responsabilidade individual das pessoas (...)”.

EAN: “(...) Como cada homem pode com suas ações contribuir para diminuir a presença da água ou provocar enchentes. A consciência que os homens devem ter para com a qualidade dos rios e lençóis freáticos(...)".

EAS: “(...) A água subterrânea está sendo contaminada com atitudes erradas de cada pessoa. Permitir que o cidadão refletisse sobre suas ações. Reconhecer as leis ambientais que protegem a água e assim, cobrar atitudes do Estado, entender e valorizar as etapas do tratamento (...)".

QAR: "(...) acho o tema água pode ser utilizado para mostrar que o meio ambiente responde as ações irresponsáveis de cada ser humano, podendo optar por uma postura diferente frente a estas ações (...)".

QAL: “(...) sempre é possível despertar a responsabilidade individual (...)”.

QAGM: “(...) os professores devem enfatizar a responsabilidade de cada um, ou seja, singular, sobre os problemas relacionados à água e apresentar as possíveis soluções para estes, além de enfatizar a necessidade de mudança de comportamento de cada pessoa (...)".

\section{Categoria: Atitude da sociedade}

Estabelecemos a categoria atitude da sociedade, pois os pesquisadores julgam importante que a escola e a comunidade abordem atitudes coletivas 
Esta categoria engloba idéias de que os projetos sobre a água que são desenvolvidos nas escolas e comunidades tem como objetivo abranger as atitudes de respeito e responsabilidade de toda sociedade em relação ao uso, distribuição e preservação deste recurso natural. Seguem os exemplos:

QAP: “(...) realizar projetos dentro da escola para o uso inteligente da água. Passar a responsabilidade aos alunos e moradores do bairro sobre o uso correto da água fora da escola".

QAL: “(...) sempre é possível salientar que todos têm que fazer sua parte, e que toda contribuição é de suma importância. Levar junto ao município e escolas projetos que abordem as etapas e o custo do mesmo, a escassez da qualidade e a legislação vigente a distribuição no planeta, visando o desenvolvimento de atitudes de responsabilidade e preservação de todos os moradores e alunos. (...)".

QAGM: “(...) Os mestres devem propor projetos com a comunidade reforçando a necessidade de alterar os hábitos da nossa sociedade, que tem uma atitude extremamente consumista".

\section{Dimensão: abordagem do tema água}

\section{Categoria: água para exemplificar temas e conceitos}

Estabelecemos a categoria água para exemplificar temas e conceitos, pois os pesquisadores relatam que, na disciplina de química, o professor, através da temática água pode exemplificar e demonstrar vários conceitos químicos.

Esta categoria engloba idéias que colocam a importância de utilizar o tema água no ensino de química para ilustrar as propriedades químicas de várias substâncias e exemplificar o processo físico- químico. Seguem os exemplos:

QAL: "(...) as questões ambientais têm sido atualmente muito discutidas e podem ser usadas para ilustrar e exemplificar as propriedades químicas de várias substâncias. Assim, por exemplo, um desenho ou comentário da estrutura molecular polar da água".

QAR: “(...), além disso, pode ser utilizada para exemplificar rapidamente uma série de conceitos/processos físico-químicos. Sim, dentre outros motivos ela está diretamente correlacionada a discussão de uma série de equilíbrios químicos"(...).

\section{Categoria: A importância da água como meio para ensinar conceitos.}

Estabelecemos a categoria importância da água como meio para ensinar conceitos, pois os pesquisadores relatam que a água é um meio que o professor pode utilizar no ensino de química para abordar conceitos científicos. 
Nesta categoria se englobam as idéias em que a água constitui-se em um caminho para o professor ensinar vários conceitos científicos como: soluções, ph e aspectos físicos- químicos- biológicos. Seguem os exemplos:

QAA: "(...) A água é um meio para ensinar conceitos químicos como ligação covalente, calor específico, pressão de vapor, temperatura, ph e equilíbrio químico devem ser conhecidos sob o aspecto físico, químico, biológico (...)".

EAN: “(...) Quando se trabalha com a água no laboratório é um meio que pode contribuir enormemente para a compreensão da constituição da água, os sais e concentrações diferentes, seu calor especifico muitas vezes alterado pelos resíduos e a abordagem de vários conceitos no ensino da química como o pH de uma solução(...)".

QAGJ: "(...) O aluno deve saber sobre a formação da água, a ligação covalente, o calor especifico, condutibilidade elétrica, ph e a solubilidade. A água permite uma abordagem fundamental com detalhes em conceitos científicos (...)".

Categoria: Importância da água como objeto do estudo.

Estabelecemos a categoria importância da água como objeto de estudo nesta questão, pois os pesquisadores relatam que através do tema água o professor pode abordar e discutir várias questões importantes que implicam diretamente na vida do estudante como: a ocorrência da chuva ácida, desertificação dos solos e a qualidade deste recurso natural.

Esta categoria engloba as idéias sobre a importância da água como objeto de estudo, pois através deste tema ambiental podemos abordar e discutir situações problemáticas, como a questão da distribuição no planeta, a qualidade de acordo com a legislação que garante a potabilidade, o tratamento da água e esgoto e atitudes de responsabilidade. Seguem alguns exemplos:

EAN: "(...) a água é um eixo que permite a abordagem de vários estudos como:desenvolver defesas contra a chuva ácida, ou o aumento da desertificação em solos fragilizados e minimizar o plantio de espécies que exigem grandes quantidades de água(...)".

EAP: “(...) podemos entender a água como um objeto importante de estudo e discussões, podendo estudar como ocorre a distribuição da água no Brasil e em outros países, as influências da sociedade no ciclo hidrológico (...)".

QAGT: “(...) sendo a água um objeto de estudo podemos discutir vários assuntos, inclusive que todo cidadão tem direito a Saneamento Básico, entender as políticas públicas da qualidade 
sendo que é um conjunto de medidas para prevenir doenças e melhorar as condições de saúde pública (...)".

EAN: "(...) Boa parte das ameaças que a água vem sofrendo se origina de seu uso direto e indireto nos processos produtivos industriais e agrícolas (...)”.

QAGM: “(...) eu entendo que a água é uma peça fundamental no ensino, e através dela podemos abordar vários assuntos importantes como: a água é um elemento vital e de grande importância para as atividades humanas, a poluição descontrolada, a legislação que garante a qualidade (...)".

Categoria: Interdisciplinaridade.

Estabelecemos a categoria interdisciplinaridade, pois os pesquisadores relatam que o professor de química para ensinar água necessita entender e realizar uma abordagem interdisciplinar.

Nesta categoria estão englobadas as opiniões sobre a importância conhecimento de várias áreas como: química, matemática, física, geografia, história e língua portuguesa, química ambiental, ou seja, a interdisciplinaridade através da água pode ser pensada no campo do ensino de química como uma possibilidade de uma nova organização do trabalho pedagógico. Alguns exemplos estão apresentados a seguir:

QAP: “(...) Conceitos básicos sobre Química Geral e Química Ambiental (...)”.

QAR: “(..) Conhecimentos gerais de ecologia, toxicologia e microbiologia.Conhecimentos gerias de orgânica, inorgânica e analítica (...)".

EAP: “(...) Entender sobre educação ambiental (...)”.

EAS: “(...) Entender um pouco de: física, biologia e geografia. Entender sobre a história das civilizações e a água. Conhecer as obras de arte sobre a água (...)”.

\section{Dimensão: visões ambientais}

\section{Categoria: Ecologia Natural}

Esta categoria, ecologia natural, engloba idéias sobre a água como um recurso vital, e finito, que há perigo da escassez, sobre a importância do ciclo da água, pois envolve todos os meios. Seguem os exemplos:

QAP: “(...) os professores devem introduzir conceitos sobre: água como fator imprescindível à vida e disponibilidade da água doce (água como um bem finito)”. 
QAR: “(..) há também a visão "contemplativa” a qual se restringe a descrever os processos biofisicoquimicos, tal abordagem também pode ser utilizada. Finalmente há formas cartesiana e holística de descrever o sistema, e mais uma vez ambas podem ser empregadas com méritos e objetivos distintos (...)"

QAM: “(...) O ciclo da água envolve todos os meios”.

\section{Categoria: Ecologia Social}

Esta categoria ecologia social, engloba as idéias sobre os poluentes lançados pelas atividades desenvolvimentistas que causam grandes impactos no meio ambiente, como a absorção de dióxido de enxofre, gases nítricos, monóxido de carbono e partículas tóxicas contaminando a água e alimentos. É necessário conscientizar, sensibilizar e envolver o estudante sobre a problemática da água, colocando ele como protagonista da situação. Seguem os exemplos:

QAP: “(...) o ciclo hidrológico com impacto antrópico, responsabilidade do ser humano no uso correto da água (...)".

EAP: “(...) desenvolvimento sustentável. Sócio ambiental (sensibilizar, envolver e realizar) tratar o estudante como protagonista".

EAN: “(...) uma das visões seria mostrar como os poluentes contidos na atmosfera ambiente são dissolvidos na água da chuva e as conseqüências que daí decorre, tais como a absorção de dióxido de enxofre, gases nítricos, monóxido de carbono e partículas tóxicas, contaminando águas potáveis e alimentos".

\section{Categoria: Conservacionismo}

Esta categoria conservacionismo, engloba as idéias sobre as atitudes de proteção, cuidado e zelo, pois a água é um recurso natural indispensável à vida. Seguem os exemplos:

QAGT: Preservação e zelo com os mananciais com objetivo de combater a degradação de recursos hídricos.

QAGS: Visão ambiental ampla de proteção e cuidado com o ecossistema, e não apenas aos usos de interesse direto dos seres humanos.

\section{Categoria: Ecologismo}

Esta categoria ecologismo, engloba as idéias sobre os atuais problemas ambientais como o desmatamento na Amazônia e a poluição dos oceanos e rios e 
possíveis formas de resolução, e qual o papel da política, economia, tecnologia e sociedade neste contexto ambiental. Seguem os exemplos:

EAS: Visões para outras áreas do conhecimento, como qual é a visão e o entendimento que o professor tem sobre a política pública da água, visão da política de outros países, como ocorre a Educação Ambiental na Europa e a visão da economia.

QAGS: Talvez então tenha faltado realçar a visão econômica que também não da para ser vista de forma isolada.

QAGT: “(..) Conhecer o trabalho que a Sabesp um órgão público realiza no segmento de educação ambiental nas escolas. Visão Política, visão social e a violência social, visão econômica".

A seguir são apresentadas as categorias de cada dimensão que envolvem as visões dos pesquisadores em Ensino de Química (EQ).

\section{Dimensão: Importância de tratar a água no ensino}

\section{Categoria: Recurso}

Estabelecemos a categoria recurso, pois através da temática água o professor pode discutir a exploração desenfreada deste recurso natural

Esta categoria engloba idéias sobre a preocupação de olhar para água como um recurso fundamental que está se tornando escasso. Este recurso vem sofrendo várias agressões como a poluição do esgoto doméstico, vazamento de óleo no oceano, resíduos industriais e agroquímicos que são lançados no rio, sendo cada vez menor a quantidade de água com qualidade para o consumo humano. Seguem os relatos:

EQR: “(...) preocupações em relação ao meio ambiente: queimadas, poluição do ar, desmatamentos, destruição de florestas e principalmente fatos relacionados à água como: poluição por esgoto doméstico, vazamentos de óleo, resíduos industriais e agroquímicos, assoreamento de rios devido a desmatamentos clandestinos e destruição de matas ciliares, causando aumento da ocorrência e da gravidade das enchentes, reservatórios destinados ao abastecimento das populações com cada vez menor quantidade e qualidade de água disponível (...).

EQM: “(...) cuja disponibilidade em \% para o consumo humano está ficando cada vez mais escassa (...)".

EQE: “(...) a utilização/exploração da água como recurso natural (...)".

\section{Categoria: Sustentabilidade}


Estabelecemos a categoria sustentabilidade, pois através da temática água o professor pode abordar assuntos como ausência de qualidade deste recurso natural para as próximas gerações.

Esta categoria, sustentabilidade, engloba idéias sobre uma preocupação com a quantidade e qualidade de água no futuro, e também a importância em ensinar e discutir este tema, pois a problemática da falta de água coloca em risco as gerações futuras. Seguem os relatos:

EQR: "(...) preocupação com a disponibilidade desta água para um futuro bastante próximo.

$E Q R$ : É de fundamental importância o ensino e a discussão sobre esse tema que se constitui, atualmente, como um dos mais graves problemas que assolam este planeta, pondo-o em risco, bem como as novas gerações (...)".

EQN: “(...) Nesse sentido, a temática água tem sido palco de muitas discussões e pesquisas e muitos dos resultados têm revelado, de um lado o discurso hegemônico da sustentabilidade e preservação ambiental e, de outro a ênfase em possibilidades "reais" de solução de problemas ambientais que extrapolam o âmbito da escola".

\section{Categoria: Vida}

Estabelecemos a categoria vida, pois através da temática água o professor pode abordar a importância deste recurso para a vida.

Esta categoria, vida, engloba idéias sobre a essencialidade da água é fundamental para a sobrevivência de todos seres vivos, isto é , é um recurso vital. Alguns relatos:

EQM: “(...) A água é fundamental para a vida e para a sociedade”.

EQN: Como conhecimento específico sempre procurou abordar os aspectos da realidade, sempre alicerçada na importância e familiaridade que a água tem para a vida dos estudantes.

EQW: A água é recurso essencial à sobrevivência dos seres vivos.

\section{Categoria: Cidadania}

Estabelecemos a categoria cidadania, pois os pesquisadores apontam que por meio do tema água, o professor pode discutir atitudes que contribuam com a formação do cidadão.

Esta categoria cidadania engloba idéias que através da água podemos discutir várias questões ambientais e sociais, explorando as atitudes necessárias 
para a formação de um cidadão responsável, consciente e justo. Seguem os relatos:

EQW: “(..) por ser um tema que possui potencialidades para ser explorado numa perspectiva de formação de cidadania; necessidade de apresentar informações que preparem os alunos para tratar responsavelmente as demandas sociais articuladas com a Ciência”.

EQR: “(...) Nesse sentido, torna-se um tema ambiental fundamental a ser abordado na formação do cidadão (...)".

EQE: “(...) Discussão sobre a água faz emergir importantes questões ambientais e de organização social, que pode ampliar a formação dos alunos no sentido do seu papel social e das responsabilidades inerentes ao mesmo, e do direito como cidadão a água potável (...)”.

\section{Dimensão: abordagem da água}

As respostas foram agrupadas em dois conjuntos:

Realidade do professor: Este conjunto refere-se a análises sobre a prática, ou seja, a atuação do professor em relação ao tema.

\section{Categoria: Subordinação}

Estabelecemos a categoria subordinação, pois os pesquisadores relatam que o professor de química se submete muitas vezes, a seqüência didática estabelecida pelo livro didático.

Esta categoria engloba as idéias sobre o tema água, que tem sido abordada, de maneira fragmentada demonstrando que os professores tem encontrado dificuldades em fazer recortes ao tema no sentido de estabelecer um conjunto limitado de conceitos. Os alunos não entendem o porquê de aprender certos conceitos químicos, o que ocorre é simplesmente, uma subordinação à seqüência do livro didático. Seguem os exemplos:

EQW: “(...) Os conteúdos químicos sobre a água têm sido abordados de forma fragmentada seqüencial, e tradicional os professores se submetem a seqüência proposta pelo livro didático (...)”.

EQE: “(...) Tenho percebido que há uma dificuldade dos professores em fazer recortes ao tema no sentido de estabelecer um conjunto limitado de conceitos a serem trabalhados. Em geral são feitas alegações sobre a necessidade de cumprir o programa exigido (...)”.

\section{Categoria: simplista}


Estabelecemos a categoria simplista, pois os pesquisadores se referem a maneira simplista com que o professor trata o tema água em suas aulas.

Esta categoria, simplista, engloba idéias que muitas vezes os professores se referem a água de uma maneira simplista atribuindo somente a importância motivacional ou de exemplificações para o ensino, deixando de tratar aspectos importantes para a sociedade. A seguir são mencionados alguns exemplos:

EQN: "(...) considero de fundamental importância para sua abordagem no ensino, que os professores reflitam sobre as concepções simplistas e motivacionais, tantos de natureza sociológica, como de conhecimento científico (...)".

EQM: “(..) muitos professores abordam a água se preocupando com o exemplos simples para motivar o aluno a aprender determinado conceito.

Possibilidades para o professor: Este conjunto refere-se ás propostas dos pesquisadores em relação a abordagem do tema.

\section{Categoria: Interdisciplinaridade}

Estabelecemos a categoria interdisciplinaridade, pois os pesquisadores se referem à maneira interdisciplinar que o professor pode tratar o tema água em suas aulas.

Esta categoria engloba idéias que o tema requer conceitos de outras áreas do conhecimento e de outras disciplinas escolares. Alguns relatos:

EQA: A interdisciplinaridade também se fez necessária. É impossível entender a fotossíntese tratando-a apenas quimicamente. Assim como outros conceitos.

EQM: O tema água permite uma abordagem de conceitos de geografia como os diferentes aqüíferos no Brasil e no mundo, biologia o estudo do metabolismo dos animais e a importância da água para o mesmo, as transformações químicas que ocorrem no tratamento da água ou seja, uma abordagem interdisciplinar.

\section{Categoria: Tema Estruturante}

Nesta categoria tema estruturante, estão incluídas as respostas dos pesquisadores que mencionam que o tema deve ser foco de estudo, englobando vários conceitos químicos e temas. Segue os exemplos:

EQM: “(...) embora possa ser tratado como um tema gerador para o estudo de conteúdos químicos deve permear todo estudo da química e sua importância na sociedade moderna". 
EQN: "(...) Penso que trata de um tema que tem um potencial bastante significativo e está fortemente presente no dia-a-dia e na vida dos estudantes".

\section{Categoria: contextualização}

Esta categoria contextualização engloba idéias que através do tema água, podem ser abordados conceitos científicos, as diferentes tecnologias, e os impactos na sociedade, permitindo assim que o aluno entenda, reflita e questione a respeito de várias situações que ocorrem no seu cotidiano e que a aprendizagem de química seja significativa para ele. Seguem os exemplos:

EQM: "(...) de forma geral, a abordagem curricular temática pode atender melhor às necessidades de formação no Ensino Médio. Por ser por área de conhecimento - no caso da Química, faz parte da área das Ciências da Natureza, Matemática e suas Tecnologias e o desenvolvimento de temáticas é mais adequado para fazer a contextualização dos conhecimentos científicos" (...).

EQN: “(...) na perspectiva educacional, a temática em questão encontra-se em qualquer contexto de ensino e, se trabalhada de maneira a considerar a complexidade inerente aos conhecimentos que perpassam cada abordagem, pode trazer importantes contribuições ao questionar o estatuto da ciência e da tecnologia diante dos desafios em relação à sustentabilidade (..)".

EQE: “(...) Em primeiro lugar, gostaria de colocar que o trabalho com a água no ensino de química, em termos gerais, pretende aproximar o estudo de conceitos científicos a realidade dos alunos (...)".

\section{Dimensão Conhecimento}

\section{Categoria Temas}

Esta categoria, temas, diz respeito aos vários assuntos mencionados pelos pesquisadores que devem ser abordados sobre a água, como: ciclo da água, formação de nuvens, fotossíntese, distribuição, contaminação, tratamento, qualidade e o seu respectivo grau de importância.

\section{Categoria Conceitos Científicos}

Esta categoria conceitos científicos engloba idéias que através da água podem ser abordados vários conceitos químicos como: funções inorgânicas, propriedades, ligações químicas, reações químicas, soluções, condutibilidade, equilíbrio químico, oxidação, tensão superficial. 


\subsection{Professores}

\subsubsection{Seleção dos professores}

Participaram desta segunda fase da pesquisa 10 professores de química do ensino médio. Os requisitos utilizados na escolha dos docentes foram:

A - Licenciado em química licenciatura plena;

B- Professor em exercício no magistério;

C- Em suas aulas realiza a abordagem da água.

A seguir, na tabela 1, apresentamos o tempo de magistério dos professores, a formação acadêmica, e também as séries e instituições que lecionam.

Tabela 1. Dados dos Professores

\begin{tabular}{|c|c|c|c|c|}
\hline Professores & $\begin{array}{l}\text { Tempo que } \\
\text { lecionam }\end{array}$ & $\begin{array}{l}\text { Formação } \\
\text { Acadêmica }\end{array}$ & Séries & Instituiçãc \\
\hline P1 & 4 anos & $\begin{array}{l}\text { Licenciatura e } \\
\text { Bacharelado em } \\
\text { Ciências e Química. }\end{array}$ & $1^{a}, 2^{a}$ e $3^{a}$ & Privada \\
\hline P2 & 15 anos & $\begin{array}{l}\text { Licenciatura e } \\
\text { Bacharelado em } \\
\text { Ciências e Química. }\end{array}$ & $1^{\mathrm{a}}, 2^{\mathrm{a}}$ e $3^{\mathrm{a}}$ & Privada \\
\hline P3 & 5 anos & $\begin{array}{l}\text { Licenciatura e } \\
\text { Bacharelado em } \\
\text { Química }\end{array}$ & $1^{\mathrm{a}}, 2^{\mathrm{a}}$ e $3^{\mathrm{a}}$ & Pública \\
\hline P4 & 8 anos & $\begin{array}{l}\text { Licenciatura e } \\
\text { Bacharelado em } \\
\text { Química }\end{array}$ & $1^{\mathrm{a}}, 2^{\mathrm{a}}$ e $3^{\mathrm{a}}$ & $\begin{array}{l}\text { Pública e } \\
\text { Privada }\end{array}$ \\
\hline P5 & 16 anos & $\begin{array}{l}\text { Licenciatura e } \\
\text { Bacharelado em } \\
\text { Ciências e Química. }\end{array}$ & $1^{\mathrm{a}}, 2^{\mathrm{a}}$ e $3^{\mathrm{a}}$ & $\begin{array}{l}\text { Pública e } \\
\text { Privada }\end{array}$ \\
\hline P6 & 5 anos & $\begin{array}{l}\text { Licenciatura e } \\
\text { Bacharelado em } \\
\text { Química. }\end{array}$ & $1^{a}, 2^{a}$ e $3^{a}$ & $\begin{array}{l}\text { Pública e } \\
\text { Privada }\end{array}$ \\
\hline P7 & 15 anos & $\begin{array}{l}\text { Licenciatura e } \\
\text { Bacharelado em } \\
\text { Ciências e Química. }\end{array}$ & $1^{a}, 2^{a}$ e $3^{a}$ & $\begin{array}{l}\text { Pública e } \\
\text { privada }\end{array}$ \\
\hline P8 & 4 anos & $\begin{array}{l}\text { Licenciatura e } \\
\text { Bacharelado em } \\
\text { Ciências e Química. }\end{array}$ & $1^{a}, 2^{a}$ e $3^{\underline{a}}$ & $\begin{array}{l}\text { Pública e } \\
\text { privada }\end{array}$ \\
\hline P9 & 13 anos & $\begin{array}{l}\text { Licenciatura e } \\
\text { Bacharelado em } \\
\text { Ciências e Química. }\end{array}$ & $1^{\mathrm{a}}, 2^{\mathrm{a}}$ e $3^{\mathrm{a}}$ & Pública \\
\hline P10 & 2 anos & $\begin{array}{l}\text { Licenciatura e } \\
\text { Bacharelado em } \\
\text { Química. }\end{array}$ & $1^{\mathrm{a}}, 2^{\mathrm{a}}$ e $3^{\mathrm{a}}$ & Pública \\
\hline
\end{tabular}




\subsubsection{Coleta de dados dos professores.}

Optamos pela realização de entrevistas, semi- estruturadas, com os professores, pois estas permitiram um contato menos formal e mais direto entre o entrevistador e o entrevistado. Além disso, a entrevista possibilita esclarecimentos imediatos de dúvidas, e a apresentação de outras questões mais específicas para cada professor.

A entrevista semi-estruturada caracteriza-se pela presença de um roteiro previamente preparado que serve de eixo orientador ao desenvolvimento da entrevista (Costa et al; 2005). Sendo assim, esse roteiro procura garantir que o participante responda ás questões, não exigindo uma ordem rígida nas respostas, o desenvolvimento da entrevista se adapta ao entrevistado e mantém-se um alto grau de flexibilidade na exploração das questões.

A entrevista foi respondida por dez (10) professores e foi estruturada da seguinte maneira:

Questão 1: refere- se à abordagem da água que é realizada pelo professor. O objetivo desta questão é o de verificar se o professor aborda a água na disciplina de química.

Questão 2: refere- se a como o professor aborda o tema água em suas aulas. O objetivo desta questão é de conhecer os conteúdos e as metodologias utilizadas pelo professor.

Questão 3: refere-se a uma tabela que construímos com conteúdos que podem ser abordado no ensino de química na temática da água, para que o professor apontasse qual conteúdo ele abordava e em que respectiva série. 0 objetivo desta questão é de conhecer em quais momentos são abordados os conteúdos apontados.

\subsubsection{Análise de dados dos professores.}

Para analisar as respostas dos professores utilizamos o instrumento que foi construído com as visões dos pesquisadores em QA, QAG, EA e EQ, a trama de conteúdos. 
Inicialmente, verificamos os temas que os professores julgam importante de serem ensinados. As gravações foram ouvidas e as notas de campo foram relidas de maneira a verificar se as categorias apontadas pelos pesquisadores estavam presentes nos discursos dos professores e se outros aspectos eram apresentados.

Em um segundo momento, analisamos aspectos relacionados à metodologia de ensino da água, e percebemos algumas tendências que permitiram para a construção das categorias de análise, utilizando alguns dos referenciais apresentados anteriormente (Freire, 2002; Auler e Bazzo, 2001; Cachapuz, 1999) os referenciais sobre a exemplificação (Cajas,2001; Lutfi,1992) permitindo a elaboração das categorias de análise da temática da água no ensino de química.

Considerando o parâmetro construído a partir das idéias dos pesquisadores $E A, Q A G, Q A$ e EQ em relação à abordagem, e esses referenciais obtidos, foram construídas 3 categorias:

Água como exemplificação do conhecimento químico: a água é apresentada através de esboços e comentários rápidos e exemplificados, como um problema ambiental ou um recurso vital, relacionado aos conceitos científicos que estão sendo abordados. Nesta categoria, os conhecimentos químicos são importantes, colocando o tema água em um plano secundário (CHASSOT, 1999; CAJAS, 2001).

Água como meio para ensinar conceitos químicos: os conceitos científicos são apresentados para explicar os temas relacionados à água, tais como: recurso, tratamento, qualidade, vida e outros.

Água como objeto de estudo: a água é tida como eixo no ensino de conceitos químicos. Os conceitos são utilizados como ferramenta para o entendimento da problemática da água, objetivando o desenvolvimento de atitudes de responsabilidade e respeito em relação a este recurso (ACEVEDO, 2003; CACHAPUZ, 1999; AIKENHEAD, 1994; DELIZOICOV et al. 2002).

Água como entendimento e transformação da realidade social: é importante a discussão sobre a problemática da água, objetivando sempre, o posicionamento e intervenção social por parte do aluno, ou seja, como protagonista na atual situação do recurso natural água. Sendo assim, os conceitos químicos são escolhidos em função de qual tema relacionado a água está sendo abordado no 
momento. Nesta categoria, as atividades propostas devem objetivar ações para transformação da realidade social estudada ( FREIRE, 2002; LUTFI, 1992).

\section{Capítulo 5. Resultados e Discussão}

\subsection{Pesquisadores}

Optamos por apresentar os dados coletados com as visões dos pesquisadores por meio da "trama dos conhecimentos"(CUELLO e NAVARRETE, 1993 apud GARCIA, 1998) ${ }^{6}$.

A trama dos conhecimentos integra vários conteúdos (conceitos, metodologias e atitudes) procedentes de várias fontes como: conhecimento científico, técnico, social e ambiental. Essa integração deve estar baseada em função da visão de mundo, sendo assim, corresponde mai a um conhecimento global do que um conhecimento disciplinar. Segundo o autor (García, 1998, p. 144):

Nessa trama há de integrar diferentes conteúdos (conceituais, procedimentais e atitudinais), provenientes de diversas fontes (conhecimento científico-técnico, práticas sociais, problemas sócioambientais, entre outros) Esta integração deve ser feita em função em função da visão de mundo adotada que, em nosso caso, corresponde mais a uma epistemologia global do que á lógica de uma determinada disciplina.

A trama dos conhecimentos dá uma visão ampla de conteúdos considerados importantes no conhecimento sobre o tema a ser estudado, bem como inclui aspectos mais gerais, que dão amplitude a trama. Como, em nosso trabalho, as contribuições dos pesquisadores (QA, QAG e EA) extrapolaram os aspectos de conteúdos (conhecimentos e atitudes), a trama foi elaborada considerando, também, os aspectos metodológicos referentes à abordagem do tema, bem como as visões ambientais implicadas no desenvolvimento do tema. A trama, dessa forma construída, está representada na figura 1, que apresenta, também, o número de pesquisadores das diferentes especialidades que citam uma determinada categoria.

\footnotetext{
${ }^{6}$ CUELLO, A. NAVARRETE, A. El água em La ciudad. Editora:Junta de Andalúcia. p.144-143, 1993.
} 


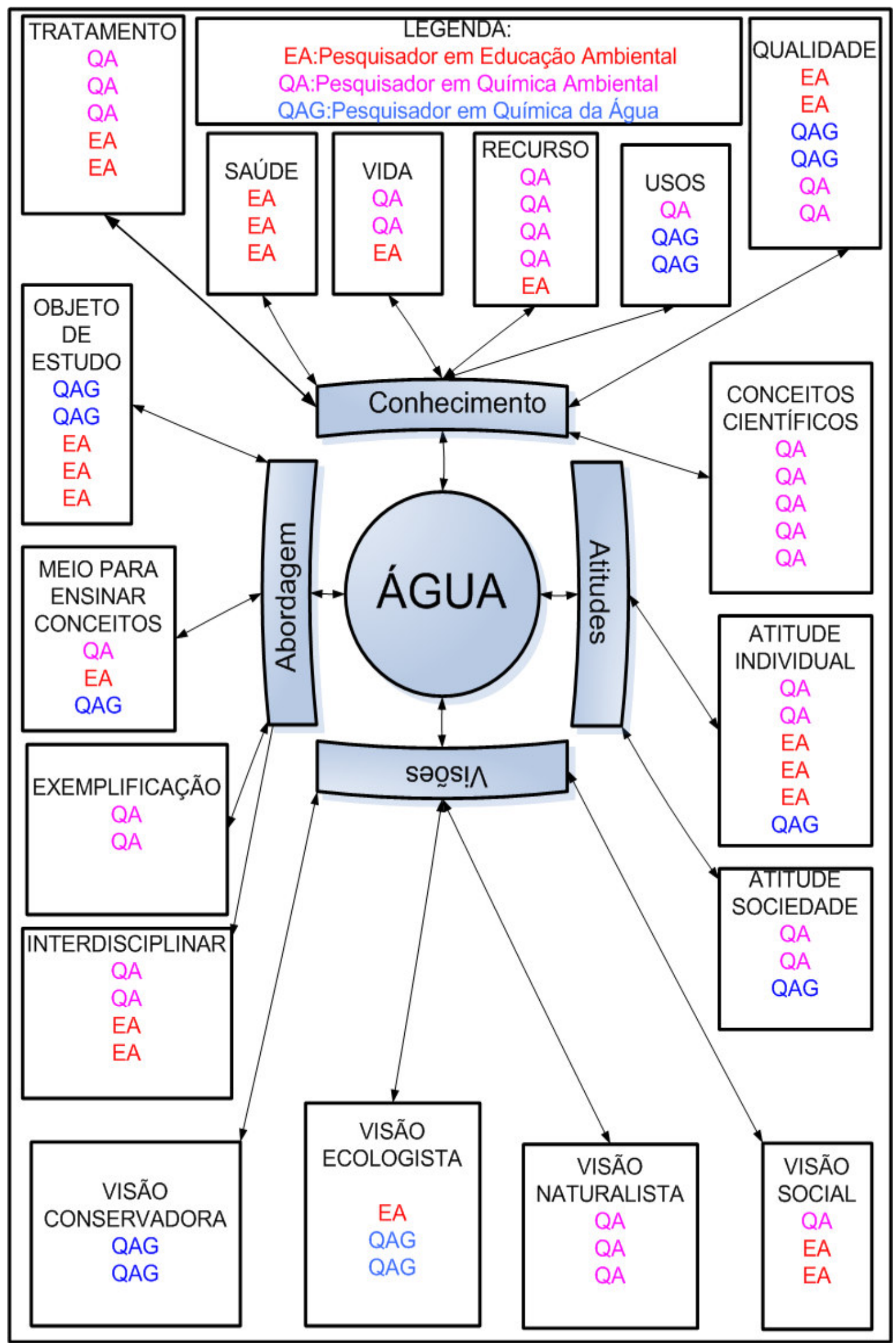

Figura 1. Visão dos pesquisadores em: QA, QAG e EA. 
A visão dos vários especialistas compõe um quadro que aponta para a necessidade de um conhecimento globalizante sobre o tema água e não um conhecimento meramente disciplinar. Como pode se observar na representação apresentada na figura 1, à trama unifica vários conteúdos, além de conhecimentos mais relacionados ao tema, como qualidade, usos, recurso, vida, saúde, tratamento, apontando também, a necessidade de que sejam tratadas atitudes, quer em termos individuais quer em termos de coletividade.

Também, a trama integra diferentes tipos de abordagens de ensino: a água como exemplificação de temas e conceitos, como meio para ensinar conceitos científicos, a água como próprio objeto de estudo e, ainda, o enfoque interdisciplinar. Também, associa várias visões ambientais como conservadora, naturalista, social e ecologista. Com relação aos pesquisadores $E Q$, também construímos uma trama de conhecimentos, considerando não apenas os conteúdos considerados importantes pelo grupo, mas também procuramos integrar outros aspectos mais gerais, relativos á metodologia de ensino e a visão que orienta ou justifica o desenvolvimento do tema. A figura 2, representa a trama construída a partir dos dados obtidos, bem como o número de pesquisadores que mencionam a categoria.

A importância atribuída pelos especialistas ao tratamento do tema em sala de aula parece revelar visões de mundo em que certos valores, relativos à cidadania, à sustentabilidade, à manutenção da vida, atuariam como marcos de referência para a seleção dos conteúdos a serem tratados sobre a temática da água. Além disso, a trama integra diferentes possibilidades metodológicas, revelando perspectivas pedagógicas que favorecem a construção de um conhecimento mais amplo e articulado do que o disciplinar. 


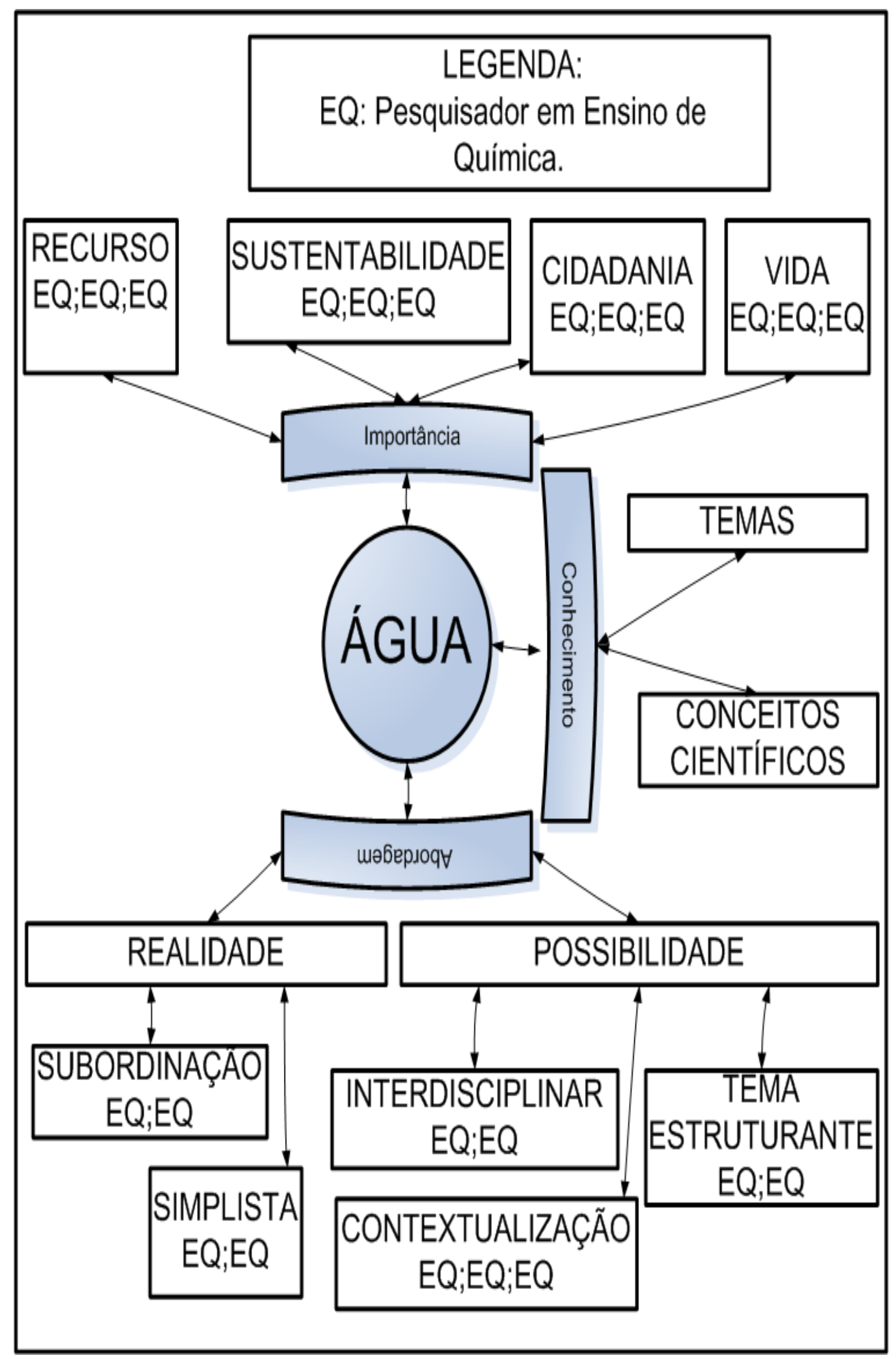

Figura 2. Visão dos pesquisadores em: EQ. 


\section{A visão dos pesquisadores em QA, QAG e EA}

Alguns elementos da trama serão destacados a seguir, por revelarem aspectos da abordagem do tema que chamam a atenção pela diversidade ou complementaridade de visões.

\section{Atitudes}

Chama a atenção, por exemplo, o destaque dado por parte de um maior grupo de pesquisadores, às atitudes individuais. São apontadas idéias a respeito de atitudes que o ser humano toma que podem contribuir com a escassez, enchente e poluição, propondo, assim, uma reflexão sobre posturas responsáveis que, individualmente, poderiam contribuir para o uso racional do recurso. Alguns pesquisadores (EA,QA e QAG) apontaram essa categoria relatando que o professor deve discutir quais são as atitudes do aluno diante deste recurso natural. As atitudes coletivas são apontadas, porém com menos ênfase, sendo citado, por exemplo, que projetos deveriam ser realizados na escola em parceria com a comunidade, visando à construção de atitudes de responsabilidade e respeito. Assim, pode-se conjecturar que esses pesquisadores percebem certo limite na ação do professor em sala de aula, ou ainda consideram temas ambientais relevantes na educação científica no sentido que os alunos entendam as "questões ambientais no contexto de suas vidas" e "suas vidas no contexto das questões ambientais" (Dillon, 2002). Poder-se-ia contrapor a esta, uma visão de ensino que incorpora o caráter político da problemática sócio-ambiental, e a democratização das decisões envolvendo a ciência e a tecnologia (Auler e Delizoicov, 2006), que parece não fazer parte das concepções da maioria dos pesquisadores.

\section{Abordagem}

Com relação à abordagem, chama atenção a pluralidade dos enfoques sugeridos, sem que haja predomínio de um deles, o que pode indicar a relevância do tema para os pesquisadores, devendo ser abordado desde uma simples exemplificação de conceitos químicos, até como um objeto de estudo. Esta última perspectiva é apontada apenas pelos especialistas em EA, que sugerem temas como: chuva ácida, desertificação do solo, o uso da água na indústria, na agricultura, a importância do recurso para vida, sua distribuição, seu tratamento e a 
conscientização sobre o custo, a legislação sobre a potabilidade e atitudes que contribuem com a qualidade da água.

Em consonância com a visão desses pesquisadores, Silva (2003), relaciona os temas que foram abordados em uma atividade didática no ensino médio tendo a água como objeto de estudo: a chuva ácida, a água em nossas vidas, qualidade da água consumida, diversidade de águas e poluição das águas.

Ainda, deve ser mencionado que quatro pesquisadores apontam que a água propicia uma abordagem interdisciplinar permeando outras disciplinas como física, biologia, geografia, ecologia, toxicologia e microbiologia. Documentos como os Parâmetros Nacionais para o Ensino Médio, PCNEM, (Brasil, 1999) apontam a necessidade de as disciplinas específicas buscarem a interdisciplinaridade no contexto do ensino.

Garcia (1998), propondo um estudo sobre a água, sugere uma trama de conteúdos centrada em quatro grandes assuntos: o ciclo da água; água e vida; água como recurso e natureza físico - química da água, abordando não apenas aspectos científicos mas também questões sociais, como usos, distribuição e escassez futura, e questões históricas, como conflitos sociais e qualidade de vida. Watanabe (2008) também propõem o desenvolvimento da temática água como foco do ensino de várias disciplinas do ensino médio. São apontados quatro focos temáticos: água e vida; água e natureza; água e história e água e sociedade, e um quinto foco, que perpassaria os anteriores, abrangendo questões relativas ao ambiente e ao clima. Na direção do que apontam alguns dos pesquisadores, as pesquisadoras propõem que a abordagem desses temas incluam aspectos políticos, sociais, econômicos e ambientais.

\section{Visões sobre 0 ambiente}

Embora não tenha havido um consenso entre os pesquisadores sobre as representações sobre o ambiente, as visões manifestadas, quando se tem como foco o ensino, parecem se complementar. Assim, como enfatizam os pesquisadores em QA, uma visão naturalista pode contribuir para que os alunos compreendam, por exemplo, como a água faz parte da natureza, como se dá sua distribuição no planeta, etc. Segundo Lago e Pádua (1984), a ecologia natural, que foi a primeira a surgir, está ligada à Química, à Física e à Geologia, uma vez que se dedica a 
estudar o funcionamento dos sistemas naturais (florestas, oceanos, etc.) procurando entender as leis que regem a dinâmica de vida da natureza. Entretanto, pode-se argumentar como bem ponderam Angotti e Auth (2001), que a visão naturalista é insuficiente para o enfrentamento da problemática ambiental.

O enfoque conservacionista também é percebido nos discursos dos pesquisadores, pois é revelada uma preocupação em cuidar e conservar o recurso natural água (Mello e Trivellato, 1999). Assim, é citada, por exemplo, a necessidade de que as pessoas desenvolvam atitudes de preservação, de proteção, de cuidado com relação à água, pois tais atitudes podem diminuir a poluição dos recursos hídricos. Embora represente uma visão um tanto ingênua da problemática ambiental, pois não considera conflitos e interesses humanos como parte desta, tal enfoque pode ser considerada importante no ensino, pois enfatiza questões urgentes relativas à poluição da água causadas por ações antrópicas e que necessitam de mudanças de comportamentos também urgentes.

Colaborando com esta visão ambiental, deve ser lembrado que os pesquisadores apontaram a valorização de atitudes individuais no ensino do tema água.

Complementando essas perspectivas ambientais centradas na preservação da natureza, foram verificadas visões que priorizam um enfoque sócio-político da problemática da água, como por exemplo, a citação de que o professor necessita ter uma visão política e econômica em relação às questões ambientais, não só no que diz respeito ao Brasil, mas a outros países; e a importância de se discutir a responsabilidade do Estado com a saúde publica e o meio ambiente.

Segundo nossa visão, é importante que tais correntes estejam presentes no ensino, pois se, de um lado, a visões mais centradas na natureza permitem que o aluno entenda como esta funciona e como surgem alguns dos problemas ambientais; as visões sócio-centradas, de outro lado, possibilitam ao aluno se enxergar como parte do ambiente. A perspectiva sócio-ambiental segundo Tiné (2007, p.255):

Não refuta as idéias conservacionistas de preservação, entretanto, a elas associa a presença humana, suas necessidades e contradições como fatores preponderantes para seus estudos. A relação sociedade- 
natureza e os processos fundamentais de co-participação são seu centro, logo apresenta uma visão de comprometimento político.

\section{Conhecimentos}

Os conhecimentos sugeridos pelos pesquisadores parecem dar uma visão bastante ampla do tema água. Ao lado de conteúdos específicos de Química, foram citados assuntos relacionados aos usos, qualidade e tratamento e vida e saúde.

Três pesquisadores (2 QAG e $1 \mathrm{EA}$ ) relatam a necessidade de se conhecer a importância da água para vida. Grassi (2001) discute que a água é um recurso fundamental para existência da vida na forma que nós a conhecemos, foi na água que a vida nasceu e seria difícil imaginar a existência de qualquer forma de vida na falta deste recurso vital.

Com relação aos usos, foram apontados tanto aspectos que dizem respeito ao uso doméstico quanto ao industrial e na agricultura. Dois pesquisadores QAG, por exemplo, discutem que é importante uma conscientização a respeito do uso da água no cotidiano, ou seja, qual é a quantidade de água utilizada para escovar os dentes, lavar louça e quintal, e em outras atividades rotineiras. Também, foi mencionada a importância de que as pessoas estejam informadas sobre a grande quantidade utilizada na indústria e na agricultura. O conhecimento sobre o uso na agricultura, segundo nossa visão, é particularmente importante, pois é aí que se dá o maior consumo de água, e a agricultura produz a maior parte dos alimentos consumidos pelo homem. Deve ser lembrado que o uso da água na agricultura é do tipo consuntivo (Grassi, 2001), ou seja, ocorrem perdas, a quantidade de água que retorna à fonte é menor do que a retirada.

Conhecimentos sobre a qualidade da água e seu tratamento foram apontados por vários pesquisadores. Assim, por exemplo, dois pesquisadores em QA julgam importante a abordagem dos parâmetros que garantem a qualidade da água, dois pesquisadores em QAG discutem que água potável é aquela que não contém substâncias e microorganismo que causam problemas a saúde pública e também, a disponibilidade de água com qualidade está cada vez mais escassa. Dois pesquisadores em EA relatam que é importante que o professor e 0 aluno conheçam o índice de qualidade determinado pela legislação. Ainda, foi 
considerado importante, por pesquisadores em EA e em $Q A$, que os alunos conheçam as etapas do tratamento da água de abastecimento.

Alguns pesquisadores manifestaram idéias que parecem estender para aspectos não apenas técnicos as questões relacionadas à qualidade e tratamento. Três pesquisadores em QA mencionam, por exemplo, aspectos econômicos associados ao tratamento, pois, segundo eles, as tecnologias para a produção de água potável a partir de efluentes contaminados existem, mas não são economicamente viáveis para uma dada realidade. É mencionada, também, a importância de se perceber que os gastos com o tratamento são compensados pela melhoria da saúde pública. Ainda, alguns pesquisadores apontam que as pessoas deveriam conhecer a legislação sobre a qualidade da água para entenderem melhor sobre este recurso e exercerem sua cidadania. Percebe-se, assim, uma visão sócio-ambiental do tema água, que pode permitir uma compreensão multidimensional da temática em questão, e contribuir para uma educação mais comprometida socialmente (TINÈ, 2007).

Cinco pesquisadores em QA julgam importante a abordagem de conceitos científicos como: aspectos químicos, físicos e biológicos da água, e também solubilidade, polaridade, equilíbrio químico, reatividade de compostos orgânicos e inorgânicos e pH. Como já mencionado, este tema propicia a inserção de vários conceitos científicos, como pode ser verificada em várias propostas de ensino de Química (KRUGUER, 2007; QUADROS, 2004; SILVA, 2003; MARCONDES et.al.; 2005; SÃO PAULO, 2007) e nos PCN+ (BRASIL, 2003).

Chama a atenção para a pouca ênfase dada pelos pesquisadores ao tratamento de esgotos domésticos, uma vez que este faz parte de nossa vida diária e os problemas decorrentes da falta de tratamento podem se refletir na qualidade de vida da população. Os livros de Química, muitas vezes, correlacionam esgoto e poluição, sem abordar as etapas do tratamento (Santos 2007). Considerando os dados obtidos em nossa pesquisa, uma possível justificativa seria devido ao fato de o tratamento de água envolver etapas cujos conhecimentos relacionados fazem parte daqueles geralmente abordados no ensino médio em Química, constando de vários livros didáticos (Santos 2007). Já os conhecimentos relativos às principais 
etapas do tratamento de esgoto não são objeto de ensino da Química, sendo, em geral, tratados na Biologia.

\section{A visão dos pesquisadores em EQ}

A trama de conteúdos, elaborada a partir das respostas dadas pelos pesquisadores em Ensino de Química que vêm trabalhando com questões relacionadas à Ciência, Tecnologia, Ambiente e Sociedade, revela aspectos relativos ao ensino do tema água que consideram tanto a prática atual dos professores, aqui chamada de realidade, como as possibilidades que o tema oferece, segundo a concepção destes pesquisadores.

\section{Importância}

Três pesquisadores citaram a importância de abordar as agressões que o recurso natural água vem sofrendo há vários anos. A sustentabilidade, a importância da água para a vida e atitudes que contribuam com a formação do cidadão.

\section{Abordagem}

As possibilidades de abordagem mencionadas dizem respeito ao tratamento interdisciplinar do tema (2 EQ), em que conceitos da Química e de outras áreas do conhecimento são inter-relacionados. Dizem respeito, também, a uma abordagem contextualizada (3 EQ), sendo mencionado, por exemplo, que tal abordagem envolve conceitos científicos, tecnologias e sociedade, aproximando a química do cotidiano do aluno, permitindo assim, uma aprendizagem significativa. Segundo Pinheiro et al.; (2007) o enfoque Ciência, Tecnologia e Sociedade CTS, possibilita questionamentos críticos e reflexivos acerca do contexto científico-tecnológico e social e, em especial, propicia uma aprendizagem significativa de conceitos. Ainda, 2 pesquisadores manifestam que a água é um tema estruturante, ou seja, um tema que propicia o estudo de vários conhecimentos e conceitos científicos de química.

Delizoicov et al.;(2002) relatam, que o temas estruturantes ou geradores, foram idealizados como um objeto de estudo que compreende o fazer e o pensar, o agir e o refletir, a teoria e a prática, permitindo um estudo do cotidiano que envolve situações individuais, sociais e históricas, construindo uma representação da atual realidade social. 
Em termos das possibilidades apontadas pelos pesquisadores em ensino de Química, percebe-se uma aproximação com algumas das visões de alguns dos especialistas das outras áreas, participantes desta pesquisa, principalmente EA, que sugerem que o tema água deve ser abordado interdisciplinarmente ou como objeto de estudo.

Quanto à realidade, pode-se perceber uma crítica às ações pedagógicas dos professores, que, segundo estes pesquisadores, ou se submetem à seqüência que tradicionalmente vem sendo seguida no ensino, subordinando-se a uma sucessão de conteúdos previamente estabelecida, ou tratam o tema de maneira simplista, sem que sejam estabelecidas relações conceituais e com a vida do aluno. Os pesquisadores mencionam, por exemplo, que, de maneira geral, apenas aspectos relacionados à poluição das águas e ao tratamento são abordados, em uma óptica de exemplificação dos conceitos ensinados. Estudos têm mostrado que os professores de química demonstram certa dificuldade em tratar os conhecimentos numa perspectiva de contextualização que valorize a reflexão e a tomada de decisões (SILVA e MARCONDES, 2007).

\section{Conhecimento}

Com relação aos conhecimentos que deveriam ser abordados no ensino desse tema, os pesquisadores em EQ valorizaram alguns conceitos químicos que não foram mencionados pelos outros pesquisadores. A tabela 2 apresenta os conceitos apontados, agrupados em tópicos de conteúdos que, de maneira geral, fazem parte do ensino médio, bem como o grau de importância atribuído à abordagem dos referidos conceitos. 
Tabela 2. Conceitos Científicos citados pelos pesquisadores em (EQ).

\begin{tabular}{|c|c|c|}
\hline Conceitos & $\begin{array}{l}\text { Grau de } \\
\text { importância }\end{array}$ & $\begin{array}{l}\mathbf{N}^{\circ} \text { de } \\
\text { pesquisadores }\end{array}$ \\
\hline $\begin{array}{l}\text { Funções Inorgânicas } \\
\text { EQA: Os sais da água podem levar ao estudo de sais e outros grupos: } \\
\text { funções inorgânicas. }\end{array}$ & 3 & \\
\hline EQR: Soluções ácidas e básicas (conceitos de Arrenhius). & 1 & \\
\hline $\begin{array}{l}\text { EQM: Água e comportamento ácido/base de substâncias nela dissolvidas } \\
\text { (produto iônico da água). }\end{array}$ & 3 & 4 \\
\hline $\begin{array}{l}\text { EQE: A água como meio para o equilíbrio ácido-base (dissociações } \\
\text { eletrolíticas em meio aquoso - soluções ácidas, alcalinas, neutras e hidrólise } \\
\text { salina). }\end{array}$ & 2 & \\
\hline $\begin{array}{l}\text { Propriedades } \\
\text { EQA: Propriedades Físicas: T.E., T.F., densidade. Pressão atmosférica e } \\
\text { pressão de vapor. }\end{array}$ & 3 & \multirow{6}{*}{6} \\
\hline EQM: Propriedades físicas e químicas. & 3 & \\
\hline EQR: Propriedades físicas da água. pressão atmosférica, pressão de vapor. & 2 & \\
\hline $\begin{array}{l}\text { EQE: Estados físicos da água e diferentes arranjos intermoleculares (o gelo } \\
\text { flutua na água líquida). }\end{array}$ & 3 & \\
\hline EQM: Diagrama de Estado. & 3 & \\
\hline $\begin{array}{l}\text { EQN: Propriedades físico química da água (densidade, ponto de ebulição, } \\
\text { ponto de fusão e capacidade calorífica). }\end{array}$ & 1 & \\
\hline $\begin{array}{l}\text { Ligações } \\
\text { EQA: Ligações químicas. A estrutura da água permite trabalhar ligação } \\
\text { covalente, a polaridade da água. }\end{array}$ & 3 & \multirow{7}{*}{7} \\
\hline EQM: Ligações químicas e a polaridade & 3 & \\
\hline $\begin{array}{l}\text { EQW: Ligação de hidrogênio e propriedades da água. Estrutura molecular } \\
\text { da água e sua geometria. }\end{array}$ & 3 & \\
\hline EQN: Ligações químicas ( ligação covalente). & 3 & \\
\hline $\begin{array}{l}\text { EQR: Constituição química; ligações químicas, geometria molecular e } \\
\text { polaridade da molécula. Eletronegatividades ligações de hidrogênio. }\end{array}$ & 3 & \\
\hline $\begin{array}{l}\text { EQM: Estrutura e geometria molecular especial da água como fonte de } \\
\text { explicacão de suas propriedades também especiais. Ligação covalente } \\
\text { entre H/O como situação muito especial para explicar propriedades } \\
\text { especiais da água. Interações intermoleculares. }\end{array}$ & 3 & \\
\hline $\begin{array}{l}\text { EQE: A estrutura molecular da água e suas propriedades numa perspectiva } \\
\text { macroscópica }\end{array}$ & 3 & \\
\hline $\begin{array}{l}\text { Reações químicas } \\
\text { EQA: Reações químicas. }\end{array}$ & 3 & \multirow{6}{*}{6} \\
\hline EQW: Reações químicas em meio aquoso. & 3 & \\
\hline EQR: Reações químicas. & 2 & \\
\hline EQN: Interações químicas. & 1 & \\
\hline $\begin{array}{l}\text { EQM: O papel da água na mobilidade iônica, na solvatação de íons e, } \\
\text { conseqüentemente, na ocorrência de transformações químicas. Equações } \\
\text { iônicas. }\end{array}$ & 3 & \\
\hline $\begin{array}{l}\text { EQM:Água como meio que permite interações entre substâncias com vistas } \\
\text { a transformações químicas. }\end{array}$ & 3 & \\
\hline $\begin{array}{l}\text { Soluções } \\
\text { EQR: Solubilidade. Propriedades coligativas. Osmose }\end{array}$ & 2 & \multirow{4}{*}{7} \\
\hline $\begin{array}{l}\text { EQW: Soluções aquosas, propriedades coligativas, cálculos de } \\
\text { concentração e de diluição. }\end{array}$ & 3 & \\
\hline EQN: Soluções / solubilidade. & 3 & \\
\hline EQM: Crioscopia. & 3 & \\
\hline
\end{tabular}


Continuação da tabela 2. Conceitos Científicos citados pelos pesquisadores em (EQ).

\begin{tabular}{|c|c|c|}
\hline Conceitos & $\begin{array}{l}\text { Grau de } \\
\text { importância }\end{array}$ & $\begin{array}{l}\mathrm{N}^{\circ} \text { de } \\
\text { pesquisadores }\end{array}$ \\
\hline $\begin{array}{l}\text { EQR: Soluções aquosas e sua importância como meio de ocorrência da } \\
\text { maioria das transformações químicas. Soluções aquosas e sua importância } \\
\text { como meio de ocorrência da maioria das transformações químicas. } \\
\text { Solubilidade, diluição e concentração de soluções aquosas. }\end{array}$ & 3 & \\
\hline $\begin{array}{l}\text { EQM: Produtos de solubilidade de substâncias pouco solúveis em água. Água } \\
\text { como solvente: características físico-químicas e capacidade de interação com } \\
\text { uma série de outras substâncias. }\end{array}$ & 3 & \\
\hline $\begin{array}{l}\text { (EQE: solubilização de poluentes, precipitação de substâncias, formação de } \\
\text { complexos, etc). }\end{array}$ & 3 & \\
\hline $\begin{array}{l}\text { Condutibilidade } \\
\text { EQR: Condutividade elétrica. }\end{array}$ & 3 & 2 \\
\hline EQR: Condutibilidade elétrica. & 3 & \\
\hline $\begin{array}{l}\text { Tensão Superficial } \\
\text { EQR: Tensão Superficial. }\end{array}$ & 3 & 2 \\
\hline EQE: Tensão superficial da água & 2 & \\
\hline $\begin{array}{l}\text { Equilíbrio químico } \\
\text { EQM: Equilíbrio químico. }\end{array}$ & 2 & \\
\hline EQW: Equilíbrio iônico da água. & 3 & 3 \\
\hline EQN: Equilíbrio ácido/base (pH, pOH, constante de ionização...). & 3 & \\
\hline $\begin{array}{l}\text { Oxidação } \\
\text { EQN: Oxidação de metais. }\end{array}$ & 3 & \\
\hline $\begin{array}{l}\text { EQR: Água e corrosão. Reações de oxi-redução e processos de redução de } \\
\text { corrosão. }\end{array}$ & 3 & 3 \\
\hline EQM: Potencial de oxidação-redução. & 2 & \\
\hline
\end{tabular}

Para fazer uma comparação entre esses dados, atribuímos uma importância relativa aos conceitos apontados, calculando a média das notas atribuídas. A tabela 3 apresenta os resultados obtidos.

Tabela 3. Média dos conceitos científicos citados pelos pesquisadores em (EQ).

\begin{tabular}{|l|l|lr|l|}
\hline Conceitos & $\begin{array}{l}\text { Soma do grau } \\
\text { de importância }\end{array}$ & $\begin{array}{l}\text { Soma do } \\
\text { número de } \\
\text { pesquisadores }\end{array}$ & Média \\
\hline Funções inorgânicas & 9 & 4 & 2,25 \\
\hline Propriedades & 15 & 6 & 2,5 \\
\hline Ligações & 21 & 7 & 3,0 \\
\hline Reações & 15 & 6 & 2,5 \\
\hline Soluções & 20 & 7 & 2,85 \\
\hline Condutibilidade elétrica & 6 & 2 & 3,0 \\
\hline Tensão superficial & 5 & 2 & 2,5 \\
\hline Equilibrio químico & 8 & 3 & 2,66 \\
\hline Oxidação & 8 & 3 & 2,66 \\
\hline
\end{tabular}


A figura 3 apresenta a importância relativa atribuída aos conceitos apontados em função do número de pesquisadores que citam tal conceito.

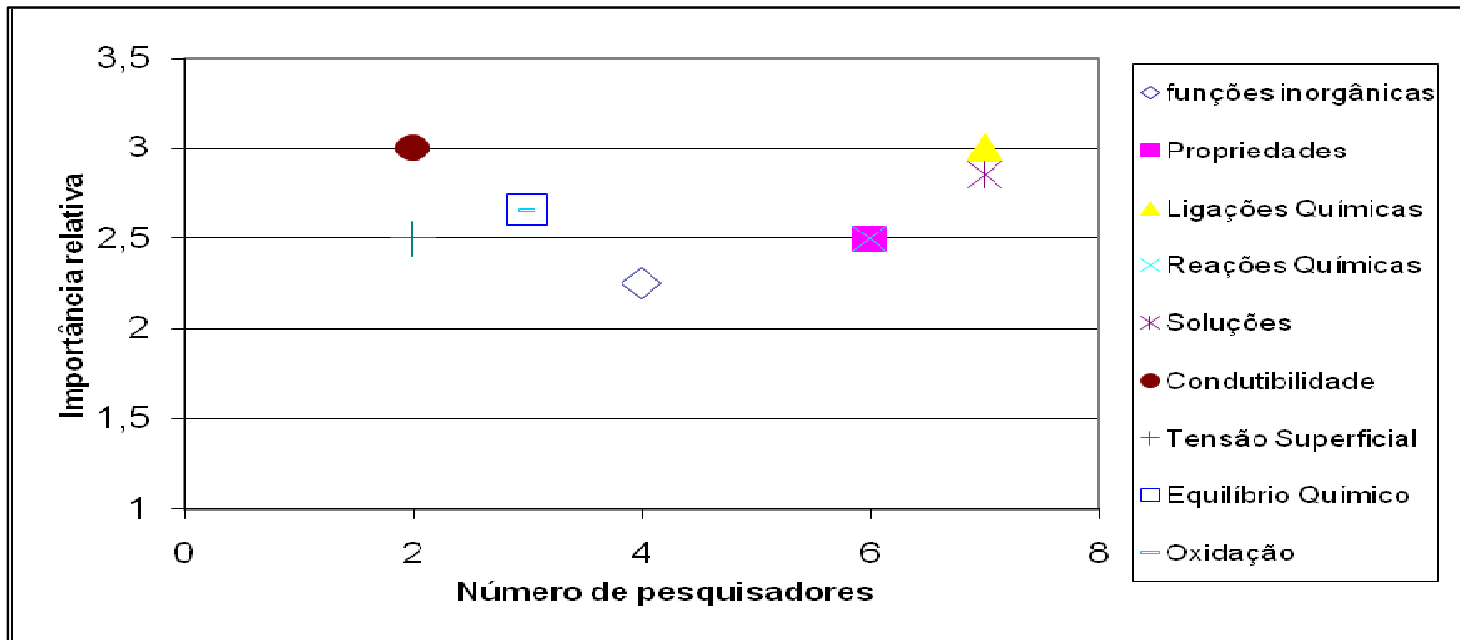

Figura 3. Importância relativa dos conceitos científicos citados pelos pesquisadores em EQ.

Analisando a figura 3 , pode-se perceber que conceitos relacionados à ligação química e a soluções são considerados importantes pela maioria dos pesquisadores em EQ. Podem-se citar, ainda, conceitos associados às propriedades da água e transformações químicas, que foram citados por (QA, QAG, EA) também valorizaram conhecimentos sobre a estrutura da água e soluções.

Como já mencionado, várias propostas de ensino sobre o tema água apresentam esses conteúdos (Kruguer, 2007; Quadros, 2004; Silva, 2003; Marcondes et. al.; 2005; São Paulo, 2007). De fato, o conhecimento das propriedades da água pode permitir ao aluno entender melhor o mundo físico, como por exemplo, o ciclo hidrológico e sua importância para a vida, a relação entre temperatura de ebulição e a pressão atmosférica, a variação de densidade da água no estado sólido e no líquido. Compreender o modelo estrutural da molécula da água pode permitir o entendimento de muitas dessas propriedades. Quanto a soluções, sua importância como conhecimento social pode ser apreciada, considerando que os materiais dissolvidos definem diferentes tipos de água e alguns de seus usos; alguns dos critérios de potabilidade estão diretamente relacionados à concentração de espécies dissolvidas. 


\section{Quanto aos temas que deveriam ser tratados quando se aborda a temática}

da água em sala de aula, a tabela 4 apresenta aqueles que os pesquisadores citaram, bem como o grau de importância atribuído.

Tabela 4. Temas citados pelos pesquisadores em (EQ).

\begin{tabular}{|c|c|c|}
\hline Temas & $\begin{array}{l}\text { Grau de } \\
\text { importância }\end{array}$ & $\begin{array}{l}\mathrm{N}^{\circ} \text { de } \\
\text { pesquisadores }\end{array}$ \\
\hline $\begin{array}{l}\text { Ciclo da água } \\
\text { EQ: Propriedades da matéria: o estudo/entendimento do ciclo da água exige o } \\
\text { estudo de temperatura, temperatura de ebulição, Temperatura de fusão, } \\
\text { pressão atmosférica, pressão de vapor e outros. }\end{array}$ & r & \multirow{5}{*}{ p } \\
\hline EQ:Ciclo geoquímico da água. & 2 & \\
\hline EQ:Hidrosfera / ciclo da água. & 3 & \\
\hline EQ:Diferentes ciclos da água: estados físicos. & 3 & \\
\hline EQ:O ciclo hidrológico e os fenômenos naturais. & 3 & \\
\hline $\begin{array}{l}\text { Formação de nuvens } \\
\text { EQ:O entendimento da formação das nuvens exige a presença do diagrama } \\
\text { de fases/ponto tríplice. }\end{array}$ & 3 & 1 \\
\hline $\begin{array}{l}\text { Fotossíntese } \\
\text { EQ:A água nas plantas leva ao estudo da fotossíntese e respiração e, após, } \\
\text { Reações Químicas. A fotossíntese exige o estudo de energia de ligação, para } \\
\text { entender a função da energia luminosa. A função da glicose na planta exige a } \\
\text { discussão de conceitos sobre alimento/nutrientes/íons, e etc.. } \\
\text { A formação das outras estruturas da planta a partir da glicose leva a outras } \\
\text { reações químicas. }\end{array}$ & 3 & \multirow[t]{3}{*}{3} \\
\hline EQ:Água na fotossíntese. & 2 & \\
\hline EQ:Fotossíntese/respiração na relação vegetais e outros seres vivos. & 3 & \\
\hline $\begin{array}{l}\text { Distribuição } \\
\text { EQ:Composição nos diferentes sistemas aquáticos, fontes e distribuição. }\end{array}$ & 2 & \multirow{4}{*}{4} \\
\hline EQ:Distribuição de fontes no planeta. & 2 & \\
\hline EQ:Distribuição da água na crosta terrestre e na hidrosfera & 2 & \\
\hline EQ:Distribuição da água no planeta & 3 & \\
\hline $\begin{array}{l}\text { Contaminação } \\
\text { EQ:Contaminação por esgoto doméstico e industrial.Poluição das águas. }\end{array}$ & 3 & \multirow{4}{*}{4} \\
\hline EQ:Contaminação das águas & 3 & \\
\hline $\begin{array}{l}\text { EQ: Principais fontes de contaminação/poluição de águas. O caso do rio Tietê, } \\
\text { por exemplo, há um documentário sobre ele. }\end{array}$ & 3 & \\
\hline EQ: Poluição da águas. & 3 & \\
\hline $\begin{array}{l}\text { Tratamento } \\
\text { EQ: Tratamento da água para consumo. }\end{array}$ & 3 & \multirow{4}{*}{4} \\
\hline EQ: Tratamento da água (tecnologias) & 3 & \\
\hline $\begin{array}{l}\text { EQ: Tratamentos da água. Conhecer a estação de tratamento de água da } \\
\text { cidade e a rede de distribuição. O custo do m cúbico de água. } \\
\text { Reaproveitamento de águas. }\end{array}$ & 3 & \\
\hline EQ:Tratamento de esgoto e água potável. & 3 & \\
\hline $\begin{array}{l}\text { Qualidade } \\
\text { EQ: Água potável }\end{array}$ & 3 & \multirow{4}{*}{4} \\
\hline EQ: Indicadores da qualidade da água.Parâmetros físico-químico da água. & 3 & \\
\hline EQ: Potabilidade das águas. & 3 & \\
\hline $\begin{array}{l}\text { EQ: Qualidade da água produção de cervejas, refrigerantes e destilados (o } \\
\text { caso da Escócia, por exemplo). Aspectos econômicos e sociais. }\end{array}$ & 2 & \\
\hline
\end{tabular}


Continuação da tabela 4. Temas citados pelos pesquisadores em EQ.

\begin{tabular}{|c|c|c|}
\hline Temas & $\begin{array}{l}\text { Grau de } \\
\text { importância }\end{array}$ & $\begin{array}{l}\mathrm{N}^{\circ} \text { de } \\
\text { pesquisadores }\end{array}$ \\
\hline $\begin{array}{l}\text { Uso } \\
\text { EQ: Uso de detergentes. }\end{array}$ & 3 & \multirow{8}{*}{ P } \\
\hline EQ: Uso. & 3 & \\
\hline EQ: Uso da água: formas e meios de economia. & 3 & \\
\hline EQ: Água na agricultura. & 3 & \\
\hline $\begin{array}{l}\text { EQ: O uso de água/pessoa em uma casa residencial. A água que bebemos } \\
\text { (propriedades) Formas de economizar água } \\
\text { A importância da água na agricultura e na indústria. O ciclo da água. As } \\
\text { importantes relações água-energia elétrica e água-transporte. As hidrelétricas } \\
\text { brasileiras. As redes fluviais no país. Custos de produção e de consumo nas } \\
\text { várias regiões do país. }\end{array}$ & 3 & \\
\hline EQ: A pressão de vapor, a irrigação e a salinização do solo. & 2 & \\
\hline $\begin{array}{l}\text { EQ: Água como substância explorada pelo homem no Planeta Terra (algo } \\
\text { diferente do que consumo, sob o ponto de vista da Química). }\end{array}$ & 2 & \\
\hline $\begin{array}{l}\text { EQ:Uso racional da água. Uso da água nos processos de cultivo e produção de } \\
\text { alimentos. Uso nos processos industriais. }\end{array}$ & 3 & \\
\hline $\begin{array}{l}\text { Política } \\
\text { EQ: Política de exploração da água: legislação, conflitos regionais etc. }\end{array}$ & 2 & \multirow[t]{2}{*}{2} \\
\hline EQ: Legislação & 3 & \\
\hline $\begin{array}{l}\text { Vida } \\
\text { EQ:Água nos organismos vivos. }\end{array}$ & 3 & \multirow{4}{*}{4} \\
\hline EQ:Água como meio que permite os fenômenos ligados à vida. & 3 & \\
\hline $\begin{array}{l}\text { EQ:A função química da água em processos de limpeza pessoal (o que ocorre } \\
\text { no banho c/ o sabonete, xampu) e na limpeza doméstica (c/ sabões e } \\
\text { detergentes). O teor de água no sangue, na urina e no suor. Explicações } \\
\text { bioquímicas de processos. A água e os processos de cozimento. Sua } \\
\text { importância na alimentação humana. }\end{array}$ & 2 & \\
\hline CTS: Importância da água nos processos biológicos vitais. & 3 & \\
\hline $\begin{array}{l}\text { Clima } \\
\text { EQ: Climatologia }\end{array}$ & 1 & \multirow{3}{*}{3} \\
\hline EQ:Climatologia. & 1 & \\
\hline EQ: A água como fator regulador do clima. & 2 & \\
\hline $\begin{array}{l}\text { Saúde } \\
\text { EQ: Doenças causadas pela restrição e pela contaminação da água no mundo e } \\
\text { no Brasil. A importância da água na saúde humana. Processos bioquímicos. } \\
\text { Consumo adequado à manutenção da vida. Regiões geográficas no mundo e no } \\
\text { Brasil que têm acesso restrito à água: conseqüências sociais, índices de } \\
\text { pobreza e de mortalidade. }\end{array}$ & 3 & 1 \\
\hline $\begin{array}{l}\text { Recurso } \\
\text { EQ: Água como recurso natural. Envolve a idéia de conservação da substância } \\
\text { (água) e que vai dispersar outras substâncias, podendo gerar poluição. } \\
\text { Tratamento de resíduos dispersos na água. Abundância relativa da água no } \\
\text { Planeta Terra como caso especial para explicar a origem da vida. }\end{array}$ & 3 & \multirow{4}{*}{4} \\
\hline $\begin{array}{l}\text { EQ: As importantes relações água-energia elétrica e água-transporte. As } \\
\text { hidrelétricas brasileiras. As redes fluviais no país. Custos de produção e de } \\
\text { consumo nas várias regiões do país. }\end{array}$ & 3 & \\
\hline EQ: Preservação das fontes de água. & 3 & \\
\hline EQ: Disponibilidade dos diferentes tipos de água no Planeta. & 3 & \\
\hline
\end{tabular}


Tabela 5. Média dos temas citados pelos pesquisadores em EQ.

\begin{tabular}{|l|l|l|l|}
\hline Temas & $\begin{array}{l}\text { Soma do grau de } \\
\text { importância }\end{array}$ & $\begin{array}{l}\text { Soma do número de } \\
\text { pesquisadores }\end{array}$ & Média \\
\hline Ciclo da água & 14 & 5 & 2,8 \\
\hline Formação de nuvens & 3 & 1 & 3,0 \\
\hline Fotossíntese & 8 & 3 & 2,66 \\
\hline Distribuição & 9 & 4 & 2,25 \\
\hline Contaminação & 15 & 5 & 3,0 \\
\hline Tratamento & 12 & 4 & 3,0 \\
\hline Qualidade & 11 & 4 & 2,75 \\
\hline Uso & 22 & 8 & 2,75 \\
\hline Política & 5 & 2 & 2,5 \\
\hline Vida & 11 & 4 & 2,75 \\
\hline Clima & 4 & 3 & 1,33 \\
\hline Saúde & 3 & 1 & 3,0 \\
\hline Recurso & 12 & 4 & 3,0 \\
\hline
\end{tabular}

Para fazer uma comparação entre esses dados, atribuímos uma importância relativa aos temas apontados, calculando a média das notas atribuídas. A tabela 5 , apresenta os resultados obtidos.

A figura 4 apresenta a importância relativa atribuída aos temas apontados em função do número de pesquisadores que citam tal tema.

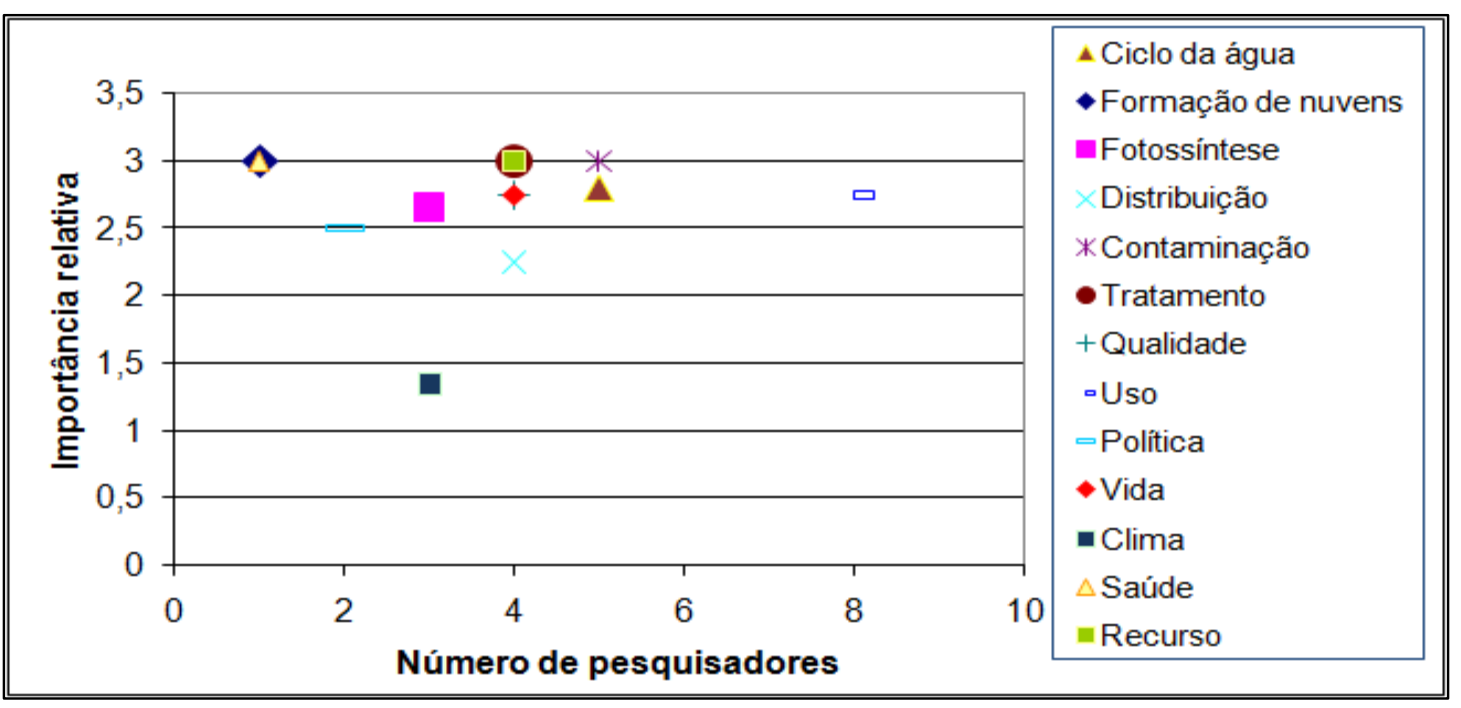

Figura 4. Importância relativa dos temas citados pelos pesquisadores em EQ.

Pode ser observado que $100 \%$ dos pesquisadores julgam importante abordar o uso da água. Como é mostrado na tabela 4, o uso mencionado está relacionado à utilização que diferentes setores da sociedade fazem e ainda ao seu uso racional. Pode-se considerar que o uso racional, de maneira geral nos meios de 
comunicação, está focado nas ações individuais que podem levar à economia no consumo da água tratada. Em geral, os livros didáticos não aprofundam esses assuntos, quando o fazem, não é sob uma perspectiva crítica (SILVA, 2007).

Assim, a valorização desses assuntos pelos pesquisadores parece apontar para uma lacuna em nosso ensino que precisa ser superada, tendo em vista a formação da cidadania crítica. Para dar um exemplo, a proposta apresenta por Watanabe e Kawamura (2005), contempla questões relacionadas aos aspectos políticos, sociais e econômicos relacionados aos usos da água.

Metade dos pesquisadores julga importante abordar temas como: distribuição, tratamento, qualidade e vida. Tais temas foram considerados importantes também pelos demais pesquisadores, o que configura um conjunto de conhecimentos e informações que deveria fazer parte da formação de um aluno do ensino médio sobre a água, e que contribuiria para a compreensão de problemas relacionados a essa temática e para possíveis posicionamentos e tomadas de atitudes, pelo menos em nível individual, sobre questões como o consumo e a poluição desse recurso natural.

\subsection{Professores}

As representações através dos mapas conceituais e as tramas de conteúdos foram elaboradas a partir da transcrição das gravações, as relações foram estabelecidas pela pesquisadora a partir das transcrições.

Representamos os conhecimentos apontados pelos professores através de mapas conceituais, pois são esquemas que indicam as relações entre temas e os conceitos. Novak (2003) propõe que o mapa conceitual é uma ferramenta para organizar e representar conhecimento. Portanto, os temas e conceitos citados pelos professores aparecem dentro de caixas enquanto que as relações entre eles são especificadas através de palavras de ligação que os unem.

Realizamos a opção por apresentar os dados coletados com as visões dos professores também por meio da "trama dos conteúdos", pois encontramos uma maneira de aproximar as visões do professores com a dos pesquisadores.

A seguir representamos os resultados referentes às análises das entrevistas de cada professor. 
O P1, em suas aulas, aborda os temas: ciclo, qualidade, tratamento e recurso, e trata também de alguns conceitos científicos. Utiliza metodologias de ensino diversificadas para abordar esses assuntos. A relação entre os conteúdos tratados e a abordagem dada está evidenciada no mapa conceitual figura 5, elaborado pela pesquisadora.

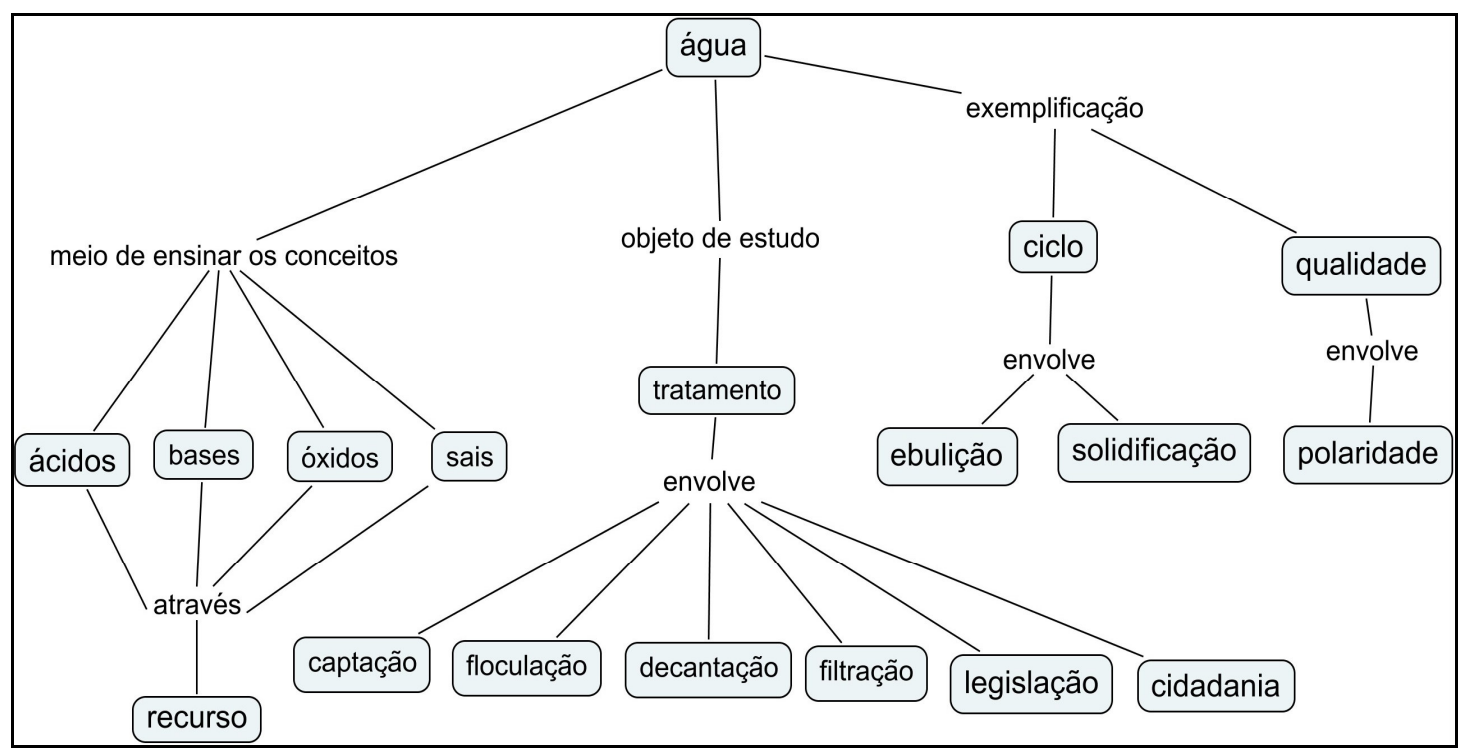

Figura 5. Mapa conceitual das idéias do P1 sobre os conteúdos tratados e como os aborda.

O professor P1 aponta os conceitos: ácidos, bases, sais e óxidos que são desenvolvidos a partir do recurso natural água. Na abordagem sobre a água, verificamos que este professor trata o tema recurso como meio para descrever vários conceitos científicos. Santos e Mortimer (1999) identificaram em sua pesquisa que o ensino de Química trata dos conceitos químicos relacionados a temas do cotidiano, sendo assim, a abordagem continua focada nos conceitos científicos.

Os pesquisadores em $Q A, E A$ e $E Q$ julgam importante a abordagem do recurso sendo ele natural e finito. No entanto, esses aspectos não são explorados por P1, pois utiliza a água como um meio para ensinar esses conceitos,como se pode perceber em seu relato:

P1: "(...) bem, eu trato no segundo ano que a água é um recurso rico em matérias primas para indústria. Inicio no laboratório explicando as funções químicas ácidos, bases, sais e óxidos nomenclatura (...) abordo esses conceitos e as tecnologias que são aplicadas após a obtenção das matérias primas deste recurso natural que é a água. Meu objetivo é que o aluno entenda que a água é um recurso ou seja um estoque que armazena milhares de matérias primas essenciais a 
industria(...)então realizamos os experimentos, atividades e exercícios no caderno sobre os conceitos científicos".

Por outro lado, a água torna-se o foco central do estudo, quando P1 aborda em suas aulas, o tratamento da água. Além de explicar cada etapa do processo, também trata de questões políticas e aborda aspectos relacionados à cidadania. Segue o relato:

P1: "(...) eu tenho um vídeo da Sabesp eu passo leva uma aula todas as etapas: represa, captação, filtração, decantação, floculação (...) depois eu explico e trago um texto da Sabesp com a legislação os parâmetros de qualidade, então explico que a água passa por várias análises e que deve obedecer a legislação da potabilidade, não explico cada análise, meu objetivo é que eles entendam que existe uma legislação e que todo cidadão tem direito a saneamento ambiental e as políticas públicas que as empresas públicas e privadas devem obedecer tudo isso após o filme. Coloco algumas questões como: Explique as etapas do tratamento. Demoro 2 aulas é difícil, muito corrido. Explique o que você entendeu sobre a legislação que garante a qualidade da água.Quem tem direito a água de qualidade? (...) meu objetivo é trabalhar cidadania, quais os direitos previstos na lei em relação á água potável (...)".

Os pesquisadores em QA, EA e EQ julgam importante que o tratamento da água seja abordado no ensino. Também questões relativas à qualidade e a legislação foram consideradas importantes por pesquisadores em QAG e EA e relativas à cidadania foram apontadas pelos $E Q$.

O professor aborda de maneira exemplificada aspectos relativos à qualidade da água, citando a poluição biológica e poluição térmica, e ao ciclo hidrológico citando os conceitos de temperatura de fusão e ebulição. Isto porque tais assuntos são apenas comentados, ou servem de exemplos para ensinar conceitos químicos. Segue o relato:

P1: "(...) a péssima qualidade da água dou uma ênfase na extinção da vida marinha, comento a polaridade da água, sem exercícios, faço um comentário rápido no final da aula sobre a poluição biológica que ocorre devido a presença de microorganismo patogênicos, a poluição térmica devido a grandes volumes de água aquecida, causando um aumento da temperatura da água,falta de oxigênio $D B O,(. .$.$) eu, falo mas não cobro em avaliações ou atividades, a poluição térmica e$ biológica, utilizo como um gancho no final da aula, (...) explico o ponto de solidificação do liquido para o sólido e ebulição do liquido para o gasoso, eu comento o exemplo do livro sobre o ciclo só o ponto de fusão e ebulição, não peço nada para avaliar, é muito rápido o comentário, não realizamos exercícios e não escrevo nada na lousa".

O tema qualidade é proposto pelo professor apenas como um exemplo, ou seja, 
um gancho para explicar um conceito. Quando explica o ciclo da água trata apenas dois conceitos de maneira exemplificada e breve. Lutfi (1992) aponta que, para alguns professores trabalhar com o cotidiano é buscar ilustrações para o assunto que está sendo abordado, ou seja, exemplos práticos que permitem ligação entre a explicação dos conceitos e as situações que envolvem o meio ambiente.

Os pesquisadores em EA, QAG e (EQ) julgam importante a abordagem do ciclo e da qualidade, como objeto de estudo.

Com relação aos conceitos citados pelos pesquisadores em EQ figura 3, atribuem uma grande importância a propriedades, ligações química, reações e soluções. Como se pode verificar pela figura 5, P1 não declarou tratar propriedades de soluções e transformações químicas, atém - se ás propriedades temperatura de fusão e de ebulição e em termos de ligações químicas, aborda a polaridade e as funções inorgânicas.

Com relação á visão ambiental, $\mathrm{P} 1$ mostrou diferentes tendências de acordo com o assunto em foco em suas aulas. Assim, P1 apresenta uma visão naturalista, pois em vários momentos explica a água através de conceitos físicos e químicos, uma visão ecologista quando trata a questão política no tratamento, e também uma visão social quando aborda que todo cidadão têm direito à água potável (LAGO e PÀDUA, 1989).

Pode- se comparar o tratamento dado por $\mathrm{P} 1$ ao tema, com a visão dos pesquisadores em QA, EA e QAG, conforme ilustrado na trama de conteúdos figura 6. 


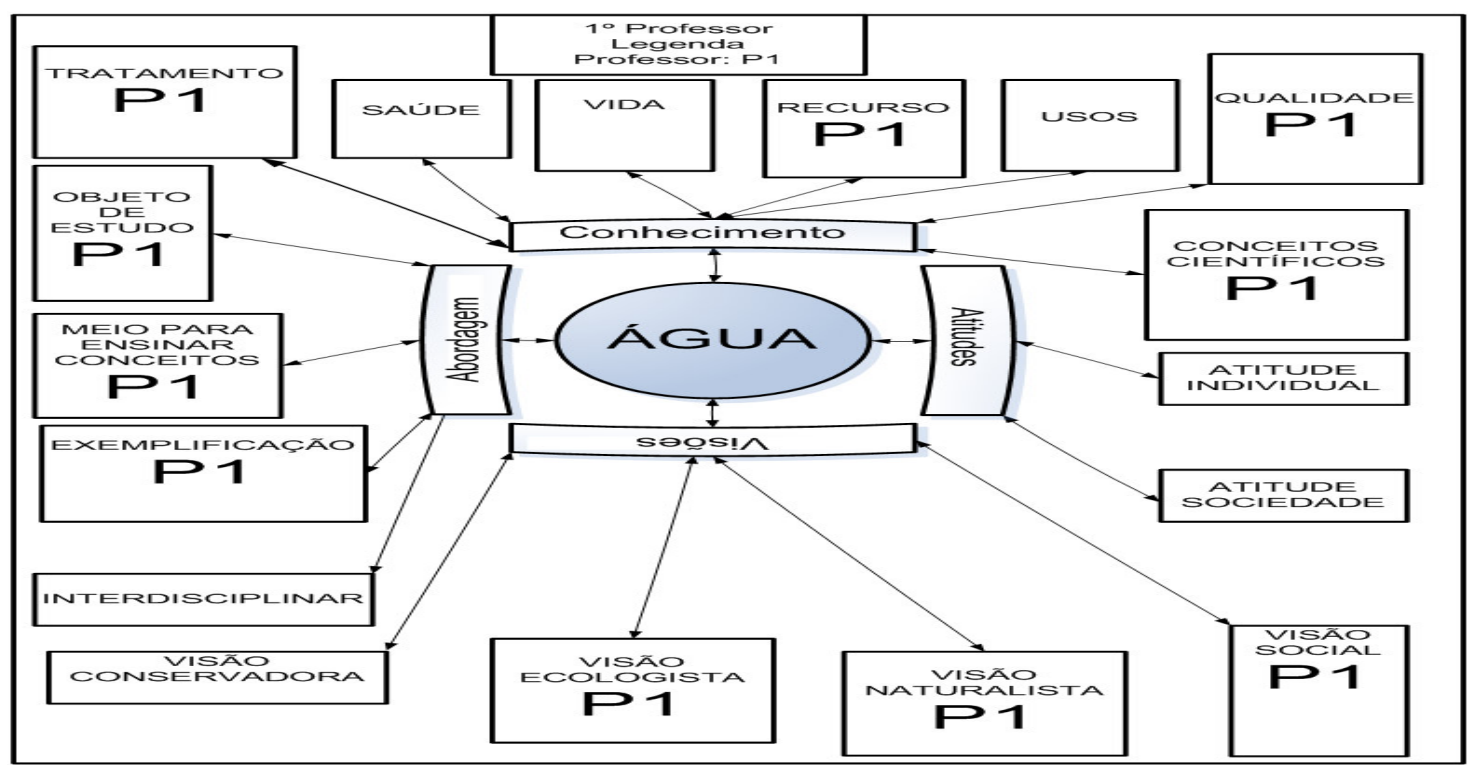

Figura 6. Trama de conteúdos (P1).

A abordagem do $\mathrm{P} 1$ está relacionada à categoria realidade, discutida pelos pesquisadores em EQ, pois parece haver uma subordinação do professor a uma organização de conteúdos que não contempla a temática água como um tema estruturante, reduzindo, praticamente, a exemplificações e apresentações de conceitos, numa visão bastante reducionista. Apenas o tratamento é abordado como um objeto de estudo.

Com relação a visão dos pesquisadores em $E Q$, a figura 7, mostra a realidade e a possibilidade do $\mathrm{P} 1$, quando aborda o tema água.

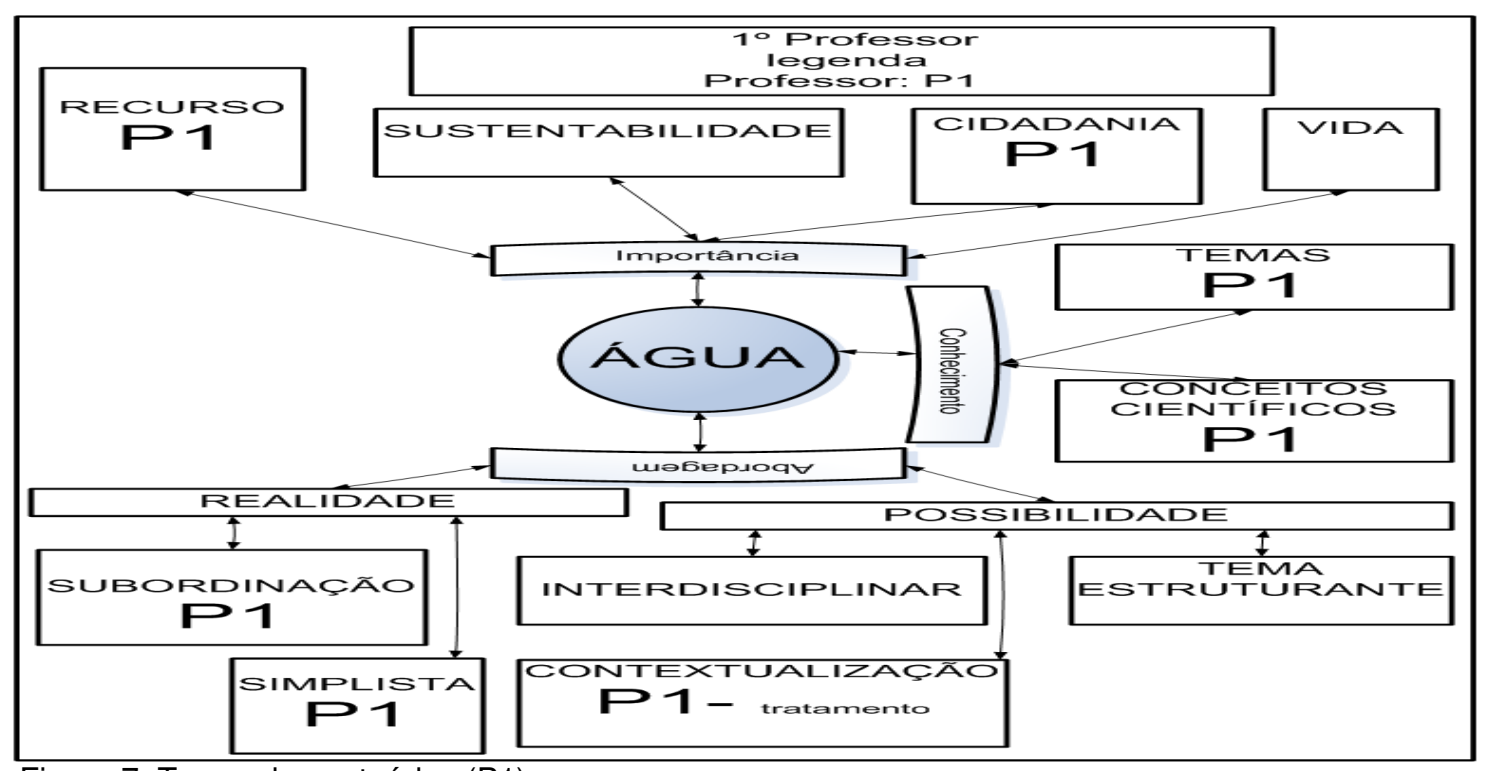

Figura 7. Trama de conteúdos (P1). 
Considerando os temas apontados como importantes no ensino pelos pesquisadores em EQ, figura 4, podemos verificar que o uso não é mencionado por P1 ( vide figura 5). Vários temas foram considerados importantes pelos demais pesquisadores, configurando-se um conjunto de conhecimentos e informação que deveriam fazer parte da formação de um aluno do ensino médio sobre a água.

Assim, podemos considerar que P1 está pouco contribuindo para que seus alunos possam ter conhecimentos que permitam uma visão mais ampla da problemática da água.

O P2 em suas aulas aborda os temas: qualidade, recurso, tratamento e ciclo, tratam também alguns conceitos científicos. Também, utiliza metodologias de ensino diversificadas. A relação entre os conteúdos tratados e a abordagem dada está evidenciada no mapa conceitual figura 8, elaborado pela pesquisadora.

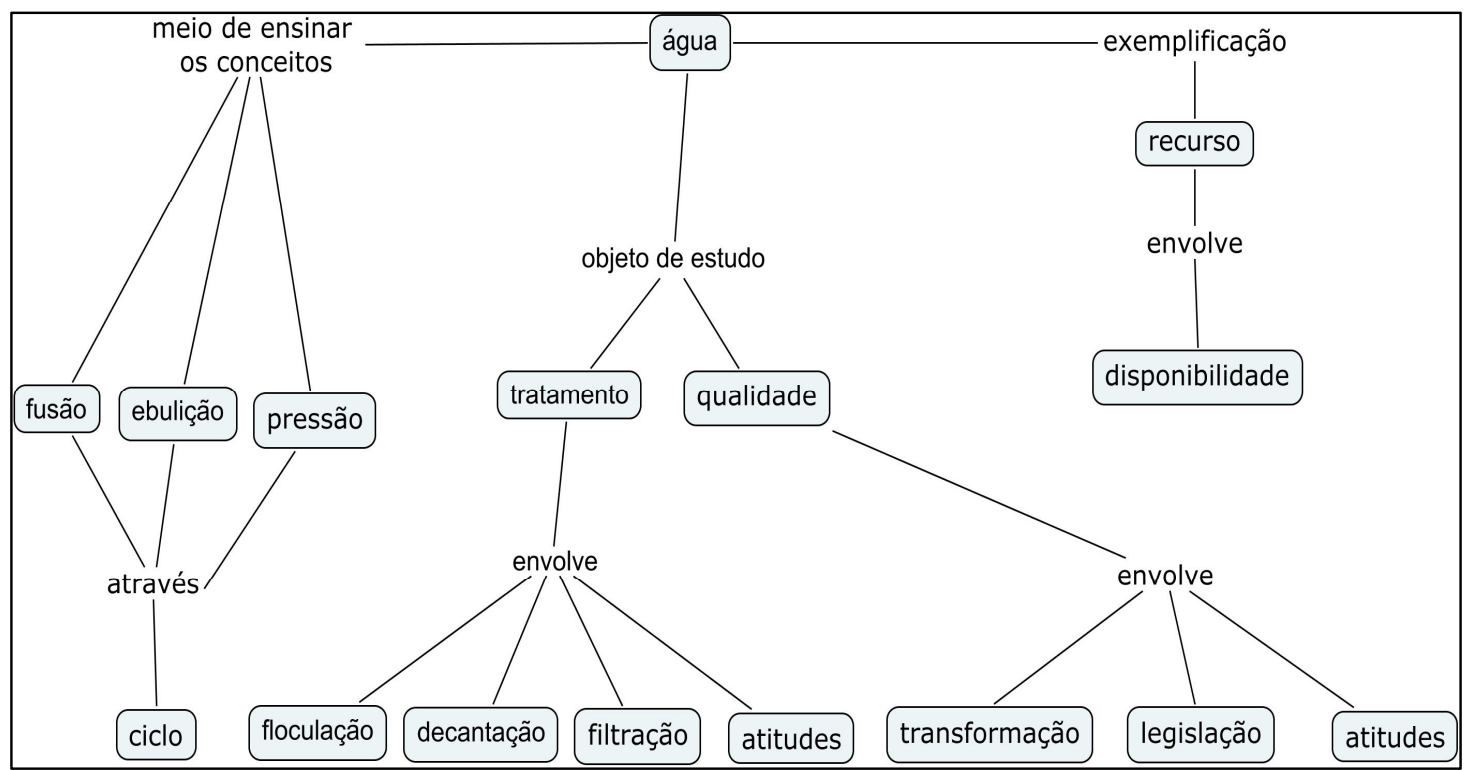

Figura 8. Mapa conceitual das idéias do P2 sobre os conteúdos tratados e como os aborda.

O professor aborda de maneira simplista aspectos relativos ao recurso, citando a perda da água que ocorre da ETA até a residência, este assunto está sendo apenas comentado. Segue o relato:

P2: “(...) então, eu ensino assim as perdas e percas do recurso água quando vamos transportar das ETA para residência que dá uns 10 e 12\% (...) então, eu ensino sempre no primeiro ano na primeira aula que as perdas e percas quando vamos transportar das ETA para residência que dá uns 10 e 12\% eu só falo rapidamente, comento a porcentagem não dou muita ênfase, eu explico mesmo com detalhes o tratamento da água que leva 5 aulas (...)".

Entretanto, P2 faz uso também, de outras abordagens mais convencionais, 
para tratar o tema água, como a exemplificação e o "dourar a pílula" como cita (LUFTI, 1992).

Os pesquisadores em QA, EA e EQ julgam importante a abordagem do recurso sendo ele natural e finito.

Por outro lado, a água torna-se o foco central do estudo, quando P2 aborda em suas aulas, o tratamento da água. Além de explicar cada etapa do processo, também aborda atitudes de desperdício e economia. Segue o relato:

P2: “(...) o aluno tem um estudo dirigido, eu elaborei que vai representar o tratamento com fotos cada etapa então eu ensino decantação, floculação, filtração (...) ensino as reações quando ocorre à floculação com o sulfato de alumínio e hidróxido de sódio que vai precipitar mostro na lousa e explico as reações de cada etapa do tratamento (...) discutimos em grupos eu solicito como atividade para entregar: Explique cada etapa do tratamento? (...) as atitudes de desperdício e economia eu trato propondo uma atividade para entregar e debate em grupo: como é tratada a água na sua casa, por favor, faça um relato? (...) o meu pai fica bravo quando aumenta o valor da conta então ele faz eu economizar naquele mês. o meu pai se preocupa com o dinheiro e não com o desperdício professora (...) então eu explico devemos utilizar somente o necessário para manutenção da vida devemos valorizar o tratamento da água pois como estudamos é longo e detalhado (...)".

Os pesquisadores de QA, EA e EQ julgam importante que o tratamento da água seja abordado no ensino, e também questões relativas a atitudes, foram consideradas importantes por pesquisadores em QA, QAG, EA e EQ .

Ainda como objeto de estudo, a água torna-se o foco central do estudo, quando P2 aborda em suas aulas, a qualidade da água através da formação da chuva ácida e as transformações químicas que ocorrem, apresentando a legislação que determina os padrões de qualidade da água e do ar. Segue o relato:

P2: “(...) eu explico a chuva ácida (...) desenho em cartolinas a avenida Paulista com vários veículos no horário do pico(...) ao lado escrevo e explico as transformações químicas que ocorrem com a queima da gasolina com as reações do enxofre formando ácido sulfúrico responsável pela chuva que vai alterar a qualidade do ar e da chuva causando um desequilíbrio ambiental (...) explico o conceito de $\mathrm{pH}$ trago um texto com o parâmetro de qualidade da Sabesp (água) e CETESB (ar) a legislação, mostro que é lei, ou seja o valor de $\mathrm{pH}$ permitido para a água potável, então explico como é realizada esta análise de $\mathbf{p H}$ e $\mathbf{p O H}$, e as concentrações dos íons $\boldsymbol{H}$ e $\mathbf{O H}$ presentes na água, depois realizamos atividades no laboratório, recolhemos amostras da chuva e medimos com o papel tornassol o valor do $\mathrm{pH}$. Então eu pergunto: Justifique a valor do $\mathrm{pH}$ no centro de São Paulo? Escreva as reações de como ocorre a formação da chuva ácida na Paulista. Cite o óxido formado pela combustão da gasolina.(...)". 
Também aborda responsabilidade individual com reportagens sobre as grandes cidades.

P2: "(...) eu trago textos do jornal estado de SP que relatam um tema: que a cada 6minutos vendem 1 carro a gasolina, e que as grandes cidades existem famílias de 4 pessoas que possuem quatro carros e trabalham no centro, lançado uma grande quantidade de enxofre no ar. Então eu coloco questões para discutirem em grupo :devemos pensar quando vamos comprar um carro movido a gasolina? Quando eu tenho um carro a gasolina, estou contribuindo com os impactos ambientais? O que você deve pensar em relação ao meio ambiente,quando o seu pai ou você for comprar um carro?trato a responsabilidade individual (...)".

Este P2 realiza uma abordagem partindo de temas que estão presentes no cotidiano do aluno visando uma reflexão, em suas atitudes. Freire (2002) relata que os temas geradores possibilitam uma problematização, ou seja, discussões sobre os fatores e problemas sociais. Podemos perceber que alguns conceitos químicos são introduzidos para que o aluno possa entender aspectos relacionados à qualidade da água e do ar e se posicionar frente a algumas situações. Esse tipo de abordagem tem sido valorizado no ensino de ciências (BRASIL, 2002; SÃO PAULO, 2008).

Os pesquisadores em QA, QAG, EA e EQ julgam importante a abordagem da qualidade e atitudes.

O professor aborda os conceitos de ebulição, fusão e pressão, utilizando o ciclo da água como meio para ensinar os conceitos científicos. Segue o relato:

P2: “(...) trato o ponto de fusão, ebulição, pressão atmosférica (...) então, explico na lousa como ocorre o ciclo da água através de gráficos com os: ponto de fusão, ebulição e pressão atmosférica relacionadas, (...) solicito papel quadriculado e construímos um gráfico para o ponto de fusão, ebulição eles entregam o gráfico para nota, explico cada conceito e depois realizamos exercícios do livro, eu cobro na avaliação bimestral, levo cinco aulas até eles entenderem estes conceitos (...)".

Os pesquisadores em EA, QAG e EQ consideram importante tratar o ciclo não como um meio, mas como o próprio objeto de estudo.

De acordo com os conceitos citados pelos pesquisadores em EQ, figura 3, atribuem uma grande importância a: propriedades, ligações química, reações e soluções. Como se pode verificar na figura 8, P2 não menciona tratar ligações e soluções, atém-se a temperatura de fusão, ebulição, variação de pressão e transformações químicas. 
Com relação a visão ambiental, P2 manifesta aspectos das várias visões aqui abordadas. Apresenta uma visão naturalista, pois em vários momentos explica a água através de conceitos físicos e químicos, e também uma visão social e conservacionista, quando trata atitudes de desperdício, economia, valorização e responsabilidade individual, e uma visão ecologista quando aborda e discute a legislação da água e do ar ( MELLO e TRIVELATO, 1999).

$\mathrm{O}$ tratamento dado por $\mathrm{P} 2$ ao tema pode- se comparar com a visão dos pesquisadores em QA, EA e QAG, conforme ilustrado na trama de conteúdos na figura 9.

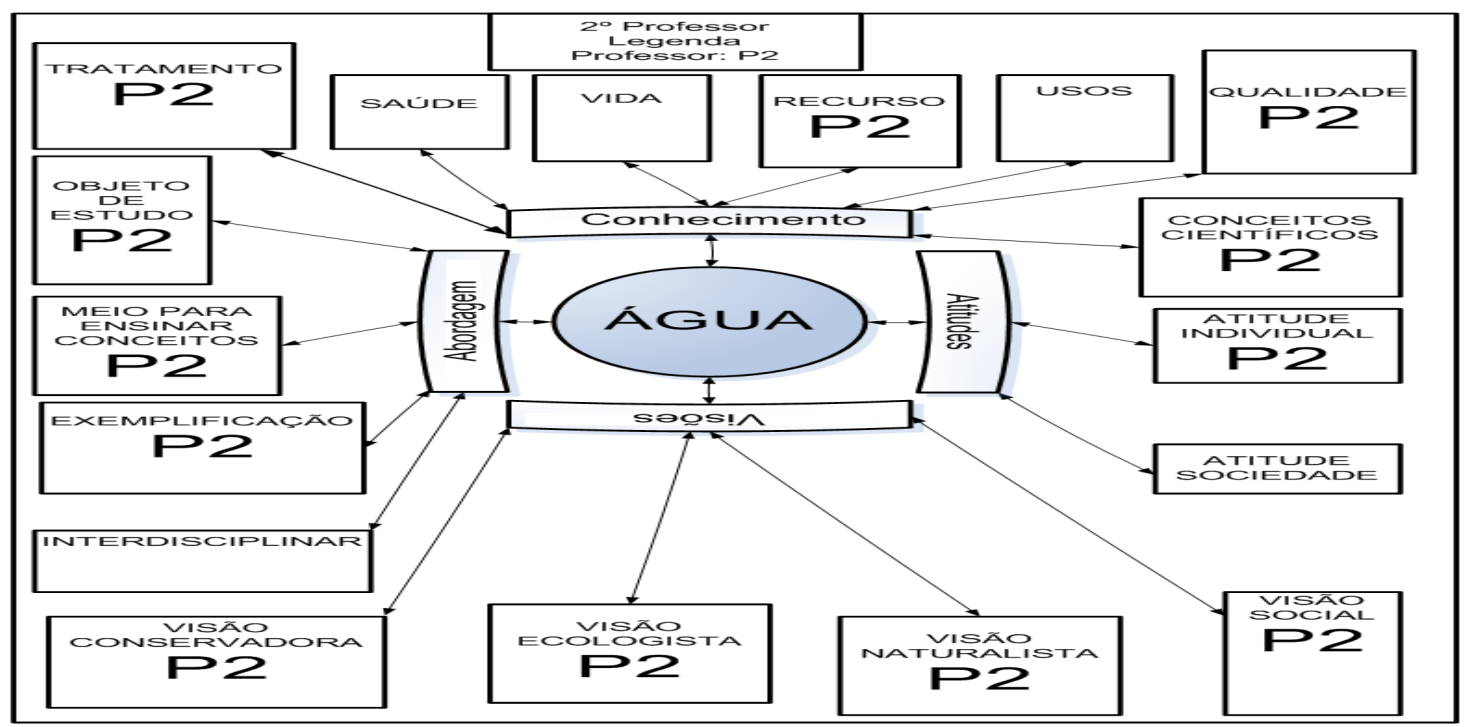

Figura 9. Trama de conteúdos (P2)

A abordagem do P2 está relacionada à possibilidade discutida pelos pesquisadores em EQ, pois em dois momentos trata a qualidade e o tratamento da água de maneira contextualizada, ou seja, como objeto de estudo, porém, em alguns momentos o professor está vinculado a uma forte subordinação de organização conceitual, reduzindo, praticamente, ao ensino de conceitos, numa visão bastante simplista.

Com relação à visão dos pesquisadores em $\mathrm{EQ}$, a figura 10 mostra a realidade e a possibilidade do $\mathrm{P} 2$, quando aborda o tema água. 


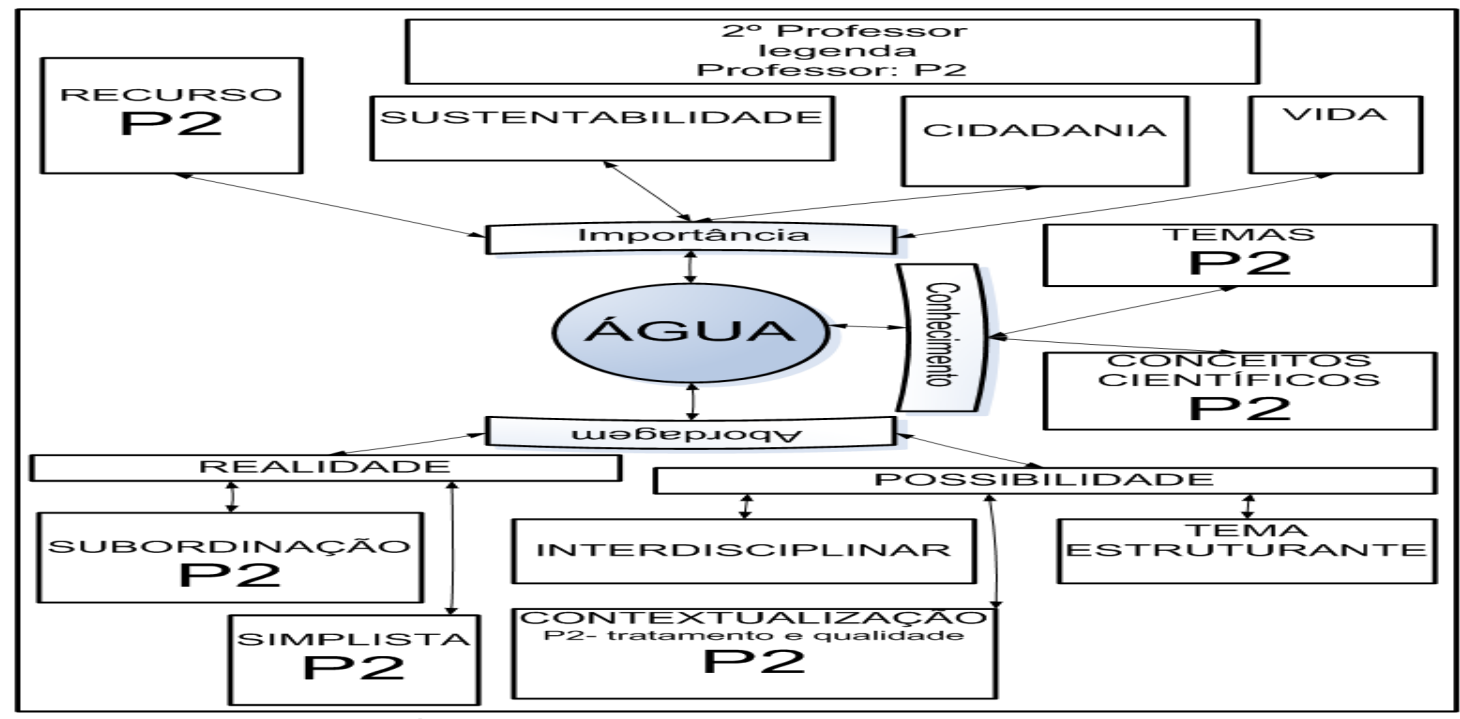

Figura 10. Trama de conteúdos (P2).

Considerando os temas apontados como importantes no ensino pelos pesquisadores em EQ figura 4, podemos verificar que o uso não é mencionado por P2 ( vide figura 8). O ciclo, embora citado, não é foco propriamente de estudo, e o tema contaminação está contemplado no estudo da qualidade da água. O professor perde uma oportunidade de discutir atitudes de responsabilidade e respeito com seus alunos, em relação ao uso exagerado da água.

O P3 aborda os temas: qualidade, uso, tratamento e ciclo, menciona também, conceitos químicos, aborda a água através de metodologias de ensino diferenciadas. A relação entre os conteúdos tratados e a abordagem dada, está evidenciada no mapa conceitual figura 11, elaborado pela pesquisadora.

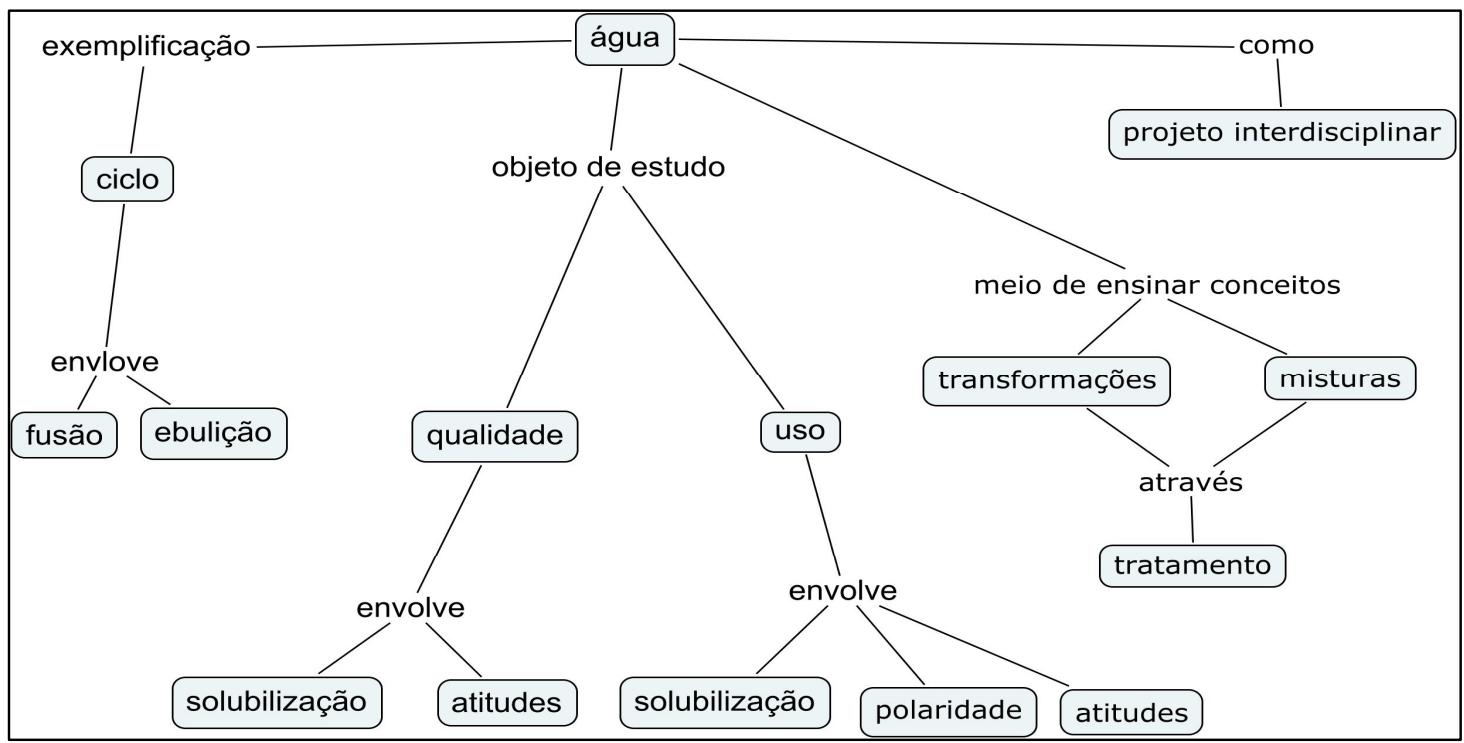

Figura 11. Mapa conceitual das idéias do (P3) sobre os conteúdos tratados e como os aborda. 
O P3 aborda de maneira exemplificada o ciclo hidrológico, apenas comenta os pontos de fusão e ebulição da água. Segue o exemplo:

P3: "(...) eu cito alguns exemplos como a transpiração do homem e animais para comentar a ebulição, a solidificação como a temperatura baixa que ocorre na geladeira (...) são exemplos bem rápidos, não cobro nada (...)".

Os pesquisadores em EA, QAG e EQ consideram importante tratar o ciclo não como exemplificação, mas como o próprio objeto de estudo.

Por outro lado, a água torna-se o foco central do estudo, quando P3 aborda em suas aulas, a qualidade da água do rio Tietê. Além de explicar o conceito de solubilização, também julga importante tratar atitudes individuais de responsabilidade que contribuem com a poluição. Segue o relato:

P3: “(...) eu abordo a qualidade escassa no Tietê, (...) o trago um vídeo que mostra o percurso do Rio Tietê, o seu inicio e a sua chegada nas grandes cidades, então após o filme explico o conceito de solubilização, pois o oxigênio dissolve-se na água em quantidades menores, o rio quando está com pouco oxigênio dissolvido em água, os peixes não sobrevivem nele, os poluidores orgânicos que são produzidos por indústrias e residências lançados no rio possibilitam uma redução do oxigênio dissolvido na água explico novamente a solubilização dos gases(...)realizamos muitos exercícios (...)após o filme coloco questões que trate da responsabilidade individual do aluno, assim: quando você lança a PET e outras embalagens na rua e no rio, você está contribuindo com a poluição? Explique (...)você é responsável pela falta de oxigênio nos rios? Explique (...)".

Os pesquisadores em QA, QAG, EA e EQ julgam importante, a abordagem da qualidade e atitudes.

Ainda como objeto de estudo, a água torna-se o foco central do estudo, quando P3 aborda em suas aulas o uso na agricultura, os conceitos de solubilidade e polaridade. Também menciona a importância da atitude de responsabilidade em relação ao uso de agrotóxicos. Segue o relato:

P3: desenho na lousa a plantação falo de quantos milhares de litros que são gastos de água tratada, ou seja, os usos indevidos depois desenho o subsolo e explico a contaminação nos lençóis com compostos orgânicos não ocorre a solubilização pois ocorre a diferença da polaridade explico o conceito de polaridade na lousa com exercícios e a explicação da plantação junto (...)tento desenvolver atitudes de reflexão e responsabilidades em relação ao uso dos pesticidas (...) peço que eles realizem uma pesquisa e apresentem um seminário de quantas toneladas de agrotóxicos são utilizadas em um mês em uma plantação de tomate em regiões diversificadas, e as conseqüências nos lençóis freáticos, então discutimos quais os benefícios e prejuízos que os 
pesticidas causam a sociedade (...) com isso tento desenvolver atitudes de reflexão e responsabilidades em relação ao uso dos pesticidas (...)".

Ao tratar da problemática da contaminação do rio Tietê e o uso da água potável na agricultura o P3 se aproxima da visão de Aikenhead (1994) que propõem no ensino de ciências que a situação problema deve partir de um tema social que tenha relação direta com conhecimentos tecnológicos e científicos, permitindo que o aluno entenda o problema e tenha uma tomada de decisão sobre questões que envolvem a sociedade.

Os pesquisadores em QAG, QA e EQ também julgam importante a abordagem do uso inadequado, e as atitudes são citadas pelos pesquisadores em QAG, QA, EA e EQ.

O professor P3 aborda os conceitos misturas e transformações químicas através do tratamento da água. Os pesquisadores em QA, EA e EQ julgam importante a abordagem do custo do tratamento para a população. No entanto, estes aspectos não são explorados por P3, pois utiliza a água como um meio para ensinar apenas conceitos científicos, como pode perceber em seu relato:

P3: "(...) desenho na lousa as etapas explico: a decantação e as misturas heterogêneas e homogêneas, a filtração simples e a vácuo, a floculação e as transformações químicas com o sulfato de alumínio utilizo duas aulas,.(...)após a explicação de cada etapa, levo eles para visitar uma estação de tratamento pois os conceitos ficam mais claros eles compreendem melhor (...)depois realizam atividades com questões para entregar como: Explique cada etapa do tratamento em detalhes. Explique o que é uma mistura heterogênea e homogênea. Escreva a reação química que ocorre na etapa da floculação. (...)".

Deve-se ressaltar, que quando aborda o tratamento da água sua preocupação é ensinar conceitos científicos, neste momento não se incomoda em tratar as tecnologias envolvidas e o papel da sociedade.

O P3 mencionou que algumas vezes participa de um projeto interdisciplinar sobre o tratamento da água, envolvendo professores de várias disciplinas e a comunidade. Demonstram através de um modelo de estação de tratamento de água todas as etapas, com esperança que os moradores valorizem a água potável e não a desperdicem. Segue o relato:

P3: "(...) projetos tratamento da água com a disciplina de matemática, física, geografia e ciências, realizamos com a comunidade as etapas do tratamento na sala de aula, uma pequena estação uma maquete, então explicamos com detalhes as etapas, o tempo gasto, os funcionários 
envolvidos, o custo do tratamento, os diferentes mananciais, para que a comunidade (os moradores do bairro) se conscientize do trabalho da estação de tratamento de água, e pense duas vezes antes de desperdiçar água tratada (...) então o objetivo é mais a atitude da valorização e conservação, que os moradores valorizem a água potável (...)".

Os pesquisadores em QA e QAG julgam importante este tipo de abordagem, e ainda os pesquisadores em QA, EQ, QAG e EA consideram importantes a questão das atitudes.

De acordo com os conceitos citados pelos pesquisadores em EQ na figura 3, atribuem uma grande importância a propriedades, ligações químicas, reações e soluções. Como se pode verificar na figura 11, P3 aborda todos estes conceitos.

O professor apresenta uma visão naturalista, pois em vários momentos explica a água através de conceitos físicos e químicos, e também uma visão social e conservadora, quando trata atitudes de responsabilidade, reflexão, valorização e conservação ( MELLO e TRIVELATO, 1999).

Pode - se comparar o tratamento dado por P3 à água, com a visão dos pesquisadores em QA, EA e QAG, conforme ilustrado na trama de conteúdos da figura 12.

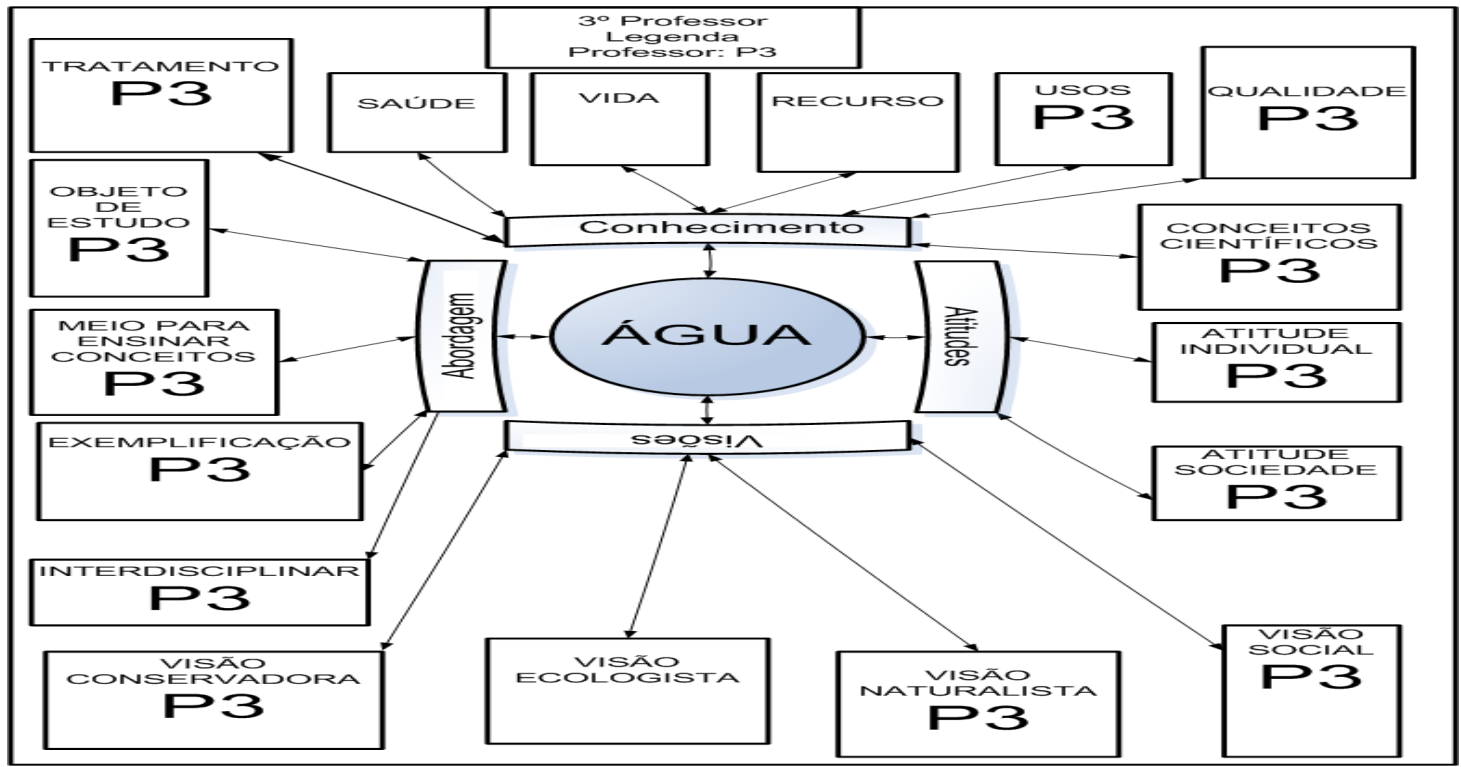

Figura 12. Trama de conteúdos (P3).

A abordagem do P3 está relacionada à possibilidade discutida pelos pesquisadores em $E Q$, pois trata a qualidade e uso da água de maneira contextualizada, e o tratamento de maneira interdisciplinar, porém, em alguns 
momentos o professor está preso a uma forte subordinação de organização conceitual e exemplificações, tendo uma visão bastante simplista.

Com relação à visão dos pesquisadores em $E Q$, a figura 13, mostra a realidade e a possibilidade do $\mathrm{P} 3$, quando aborda a água.

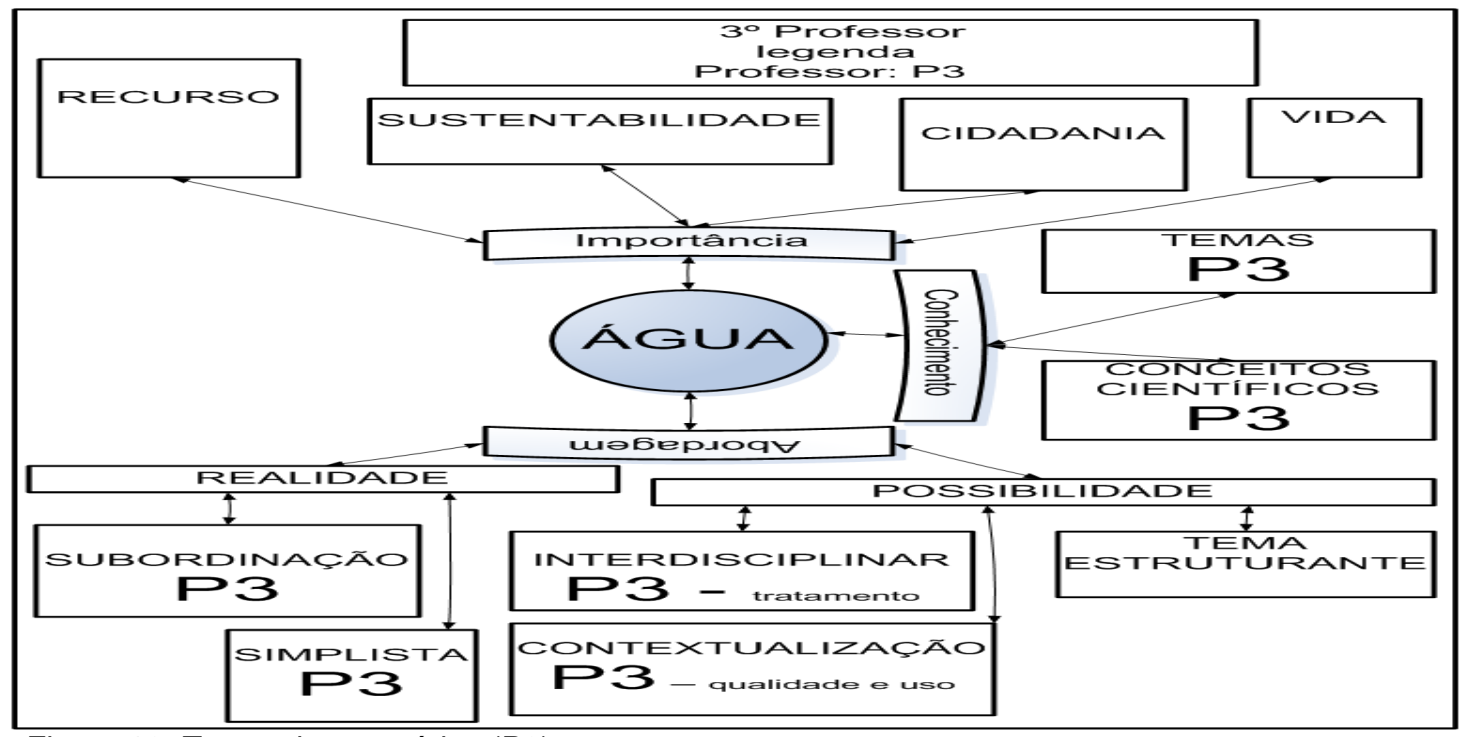

Figura 13. Trama de conteúdos (P3).

Dos temas considerados importantes pelos pesquisadores em EQ figura 4, P3 aborda o ciclo, a contaminação e o uso figura 11. O ciclo hidrológico embora tenha sido mencionado, é apenas um facilitado para o tratamento de alguns conceitos científicos. Este professor contribui com o desenvolvimento de atitudes pró- ambientais em seus alunos, pois discute atitudes de responsabilidade em relação ao uso da água.

O P4 aborda os temas: qualidade e ciclo tratam também alguns conceitos científicos, aborda a água através de metodologias de ensino diversificadas. A relação entre os conteúdos tratados e a abordagem dada está evidenciada no mapa conceitual figura 14 , elaborado pela pesquisadora. 


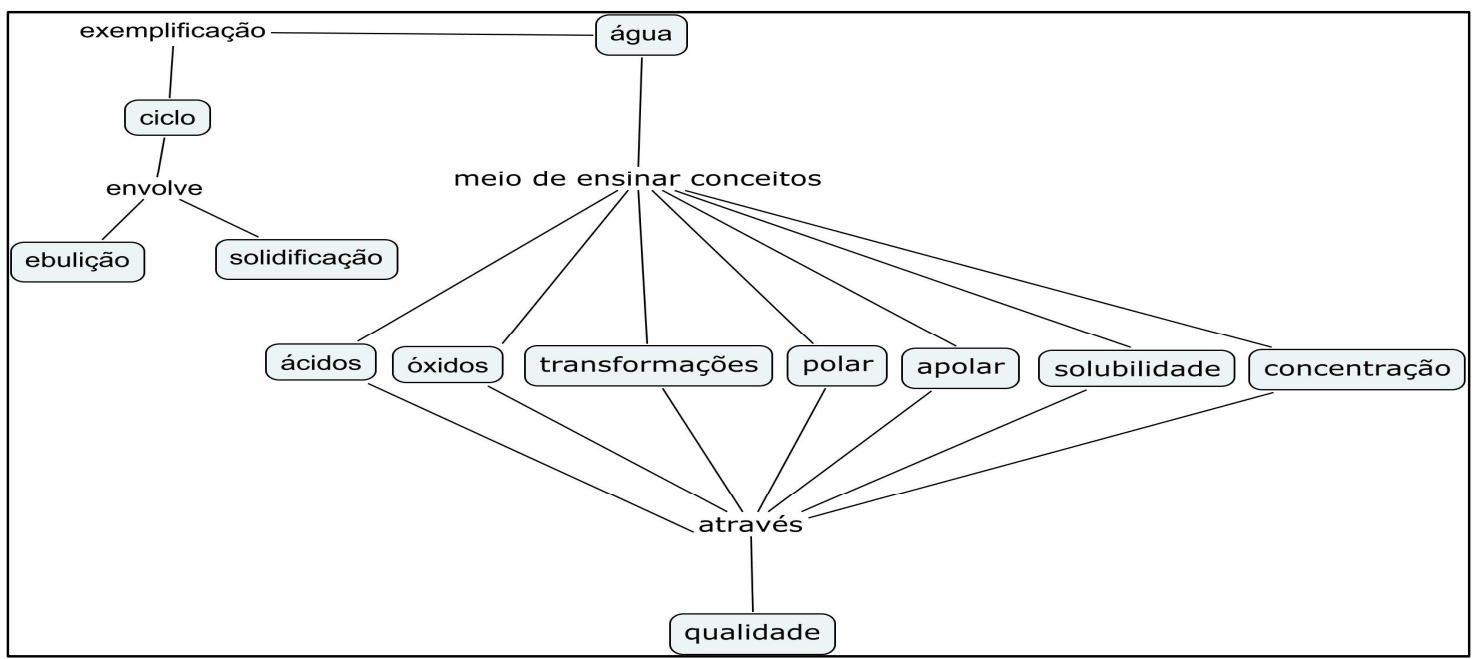

Figura 14. Mapa conceitual das idéias do (P4) sobre os conteúdos tratados e como os aborda.

O professor P4 aborda os conceitos: ácidos, óxidos e as transformações químicas através da chuva ácida, e também os conceitos polar, apolar e solubilidade pelo meio dos acidentes causados através de navios petroleiros. Trata a concentração de metais, apontando a falta de qualidade nos rios. O P4 trata a chuva ácida, a contaminação dos oceanos e lagos através dos conceitos científicos envolvidos, sua priorização é que o aluno entenda conceitos. Em sua abordagem, P4 não se preocupa em abordar as tecnologias envolvidas e a responsabilidade social, que influenciam de maneira direta nestes impactos ambientais.

Os pesquisadores em QA, QAG, EA e EQ julgam importante a abordagem dos parâmetros da qualidade através da legislação, e a importância da potabilidade da água para a vida do homem e atitudes de conservação.

No entanto, estes aspectos não são explorados por P4, pois utiliza a água como um meio para ensinar apenas conceitos científicos, como pode perceber em seu relato:

P4: “(...) trago textos sobre chuva ácida (...) que relatava sobre os processos biológicos de alguns microorganismos e plantas presentes em ambientes marinhos e que eles produzem compostos de sulfeto de hidrogênio, então explico a as reações e as funções ácidos e óxidos (...) após o texto coloco questões para entregar como: Escreva a reação química.(...) peço que os alunos tragam notícias sobre os acidentes causados pela Petrobras nos oceanos, então explico a polaridade (polar e apolar) orgânicos e água por isso que não ocorre a solubilidade com exercícios na lousa, (...) olha como eles entendem a polaridade (...)trago slides de indústrias de galvanoplastia que os processos utilizam metais: cobre, zinco e chumbo e descartam nos rios (...) explico que esta alta concentração causam alterações no metabolismo dos peixe (...)explico o conceito da concentração na lousa com a fórmula como calcular esta concentração de metais na 
água (...) solicito uma atividade para calcular a concentração eu forneço as toneladas de metais e o volume de água (...)"

O P4 aborda de maneira exemplificada o ciclo hidrológico, somente comenta os pontos de evaporação e fusão da água. Segue o relato:

P4: “(...) sou breve para explicar o ciclo sempre tem aquele exemplo do livro básico e rápido, eu falo da evaporação e solidificação (...) a abordagem é só um exemplo, não tenho muito tempo é muito corrido são duas aulas, é complicado, não dou exercícios e nem cobro em avaliações o ciclo (...)".

Os pesquisadores em EA, QAG e EQ consideram importante tratar o ciclo não como exemplificação, mas como o próprio objeto de estudo.

De acordo com os conceitos citados pelos os pesquisadores em EQ, figura 3, atribuem uma grande importância a: propriedades, ligações química, reações e soluções, sendo que encontramos todos na abordagem do P4 (figura 14).

O professor apresenta uma visão naturalista, pois explica a chuva ácida e a contaminação através de conceitos científicos ( MELLO e TRIVELATO, 1999).

O tratamento dado por P4 a água, pode-se comparar com a visão dos pesquisadores em QA, EA e QAG, conforme apresentado na trama de conteúdos da figura 15.

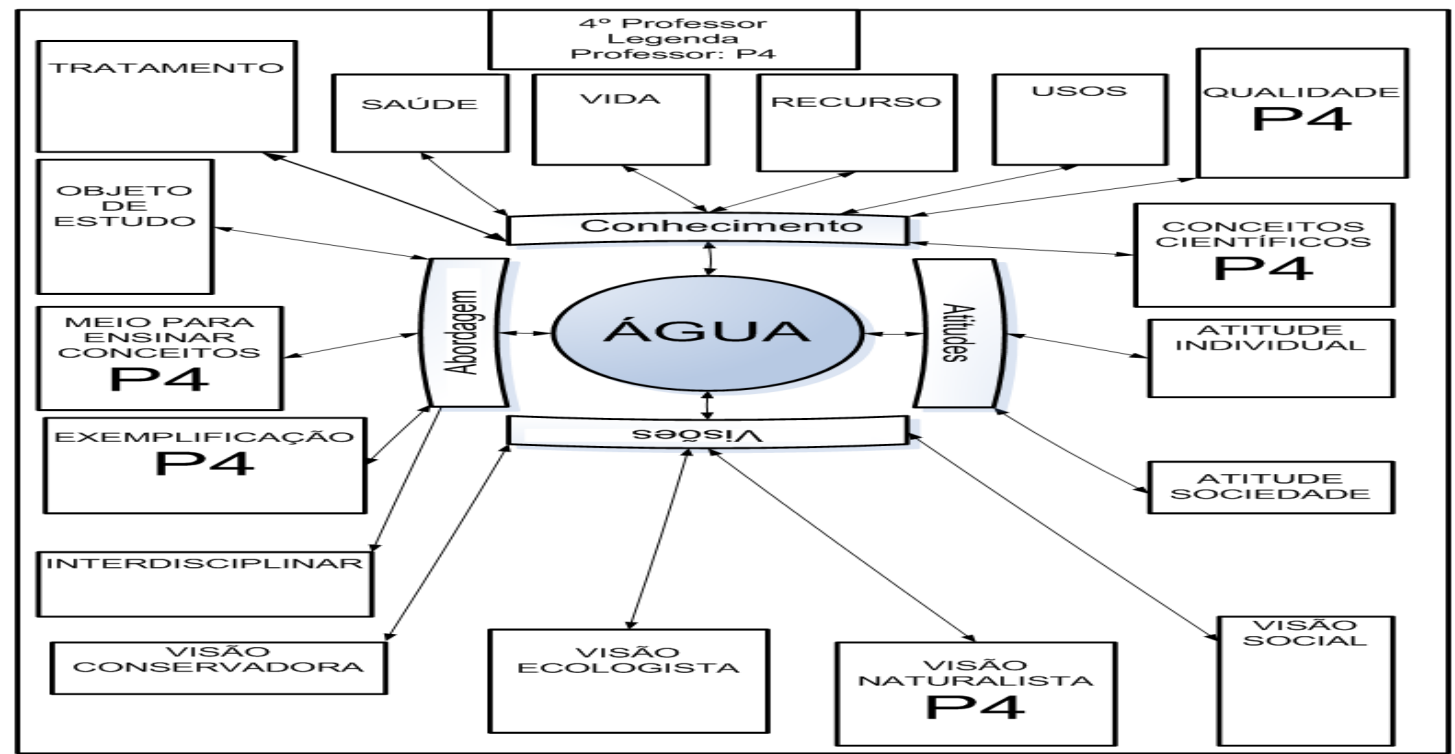

Figura 15. Trama de conteúdos (P4).

A abordagem do P4 está relacionada à categoria realidade de ensino discutida pelos pesquisadores em EQ, pois trata a qualidade da água através de descrição e subordinação conceitual, e também o ciclo através de exemplificações, 
tendo uma visão vastamente reducionista.

Com relação à visão dos pesquisadores em EQ, a figura 16 mostra a realidade e possibilidade do $\mathrm{P} 4$, quando aborda a água.

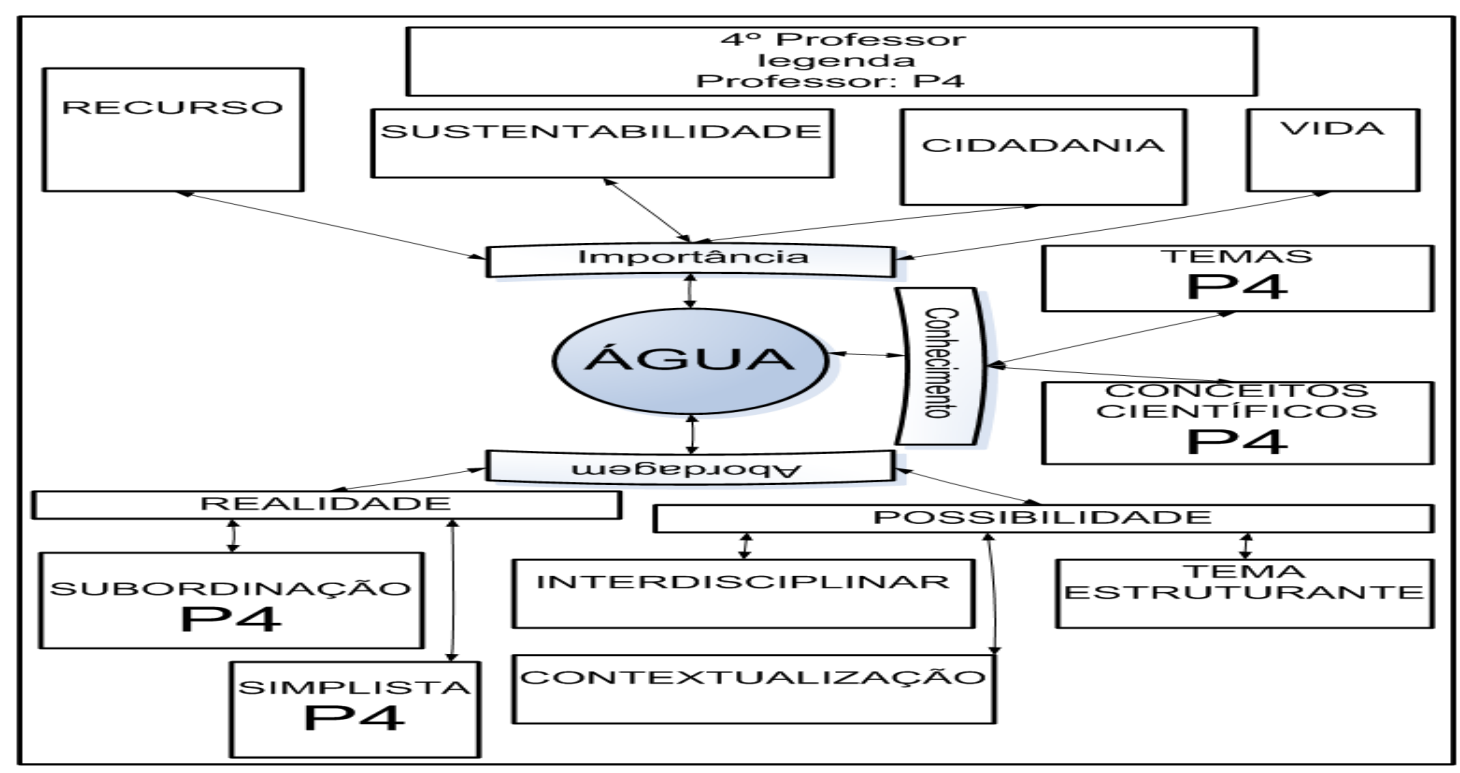

Figura 16. Trama de conteúdos (P4).

Considerando os temas apontados como importantes no ensino pelos pesquisadores em EQ figura 4, podemos verificar que o uso não é mencionado por P4 (vide figura 14). O tema contaminação está contemplado no estudo da qualidade da água. As atitudes errôneas a respeito do uso, não são abordadas pelo professor, limitando o conhecimento do aluno em relação á problemática da água.

O P5 aborda os temas: qualidade e tratamento e, também, alguns conceitos científicos, aborda a água através de metodologias de ensino diversificadas. A relação entre os conteúdos tratados e a abordagem dada está evidenciada no mapa conceitual figura 17, elaborado pela pesquisadora. 


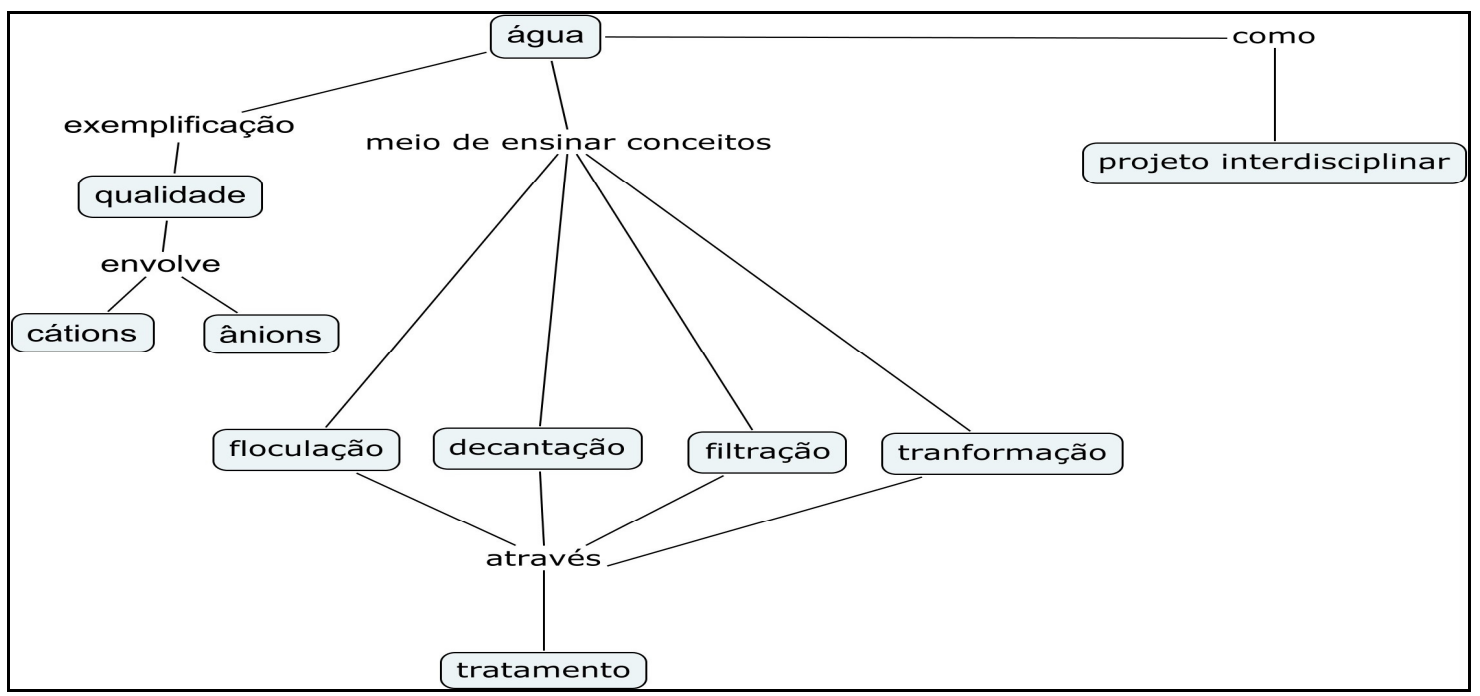

Figura 17. Mapa conceitual das idéias do (P5) sobre os conteúdos tratados e como os aborda.

O P5 aborda de maneira exemplificada os aspectos relativos a falta de qualidade da represa Billings, citando apenas os conceitos de cátions e ânions. Segue o relato:

P5: "(...) eu explico o conceito de íons os cátions e anions no $2^{\circ}$ ano na lousa fazendo a ligação do fosfato e do cloreto de sódio, mas não cobro nada no bimestre deste assunto(...)faço um gancho no final da aula falo sobre a represa Billings que o esgoto contendo resíduo de detergentes que contem íons de fosfato são lançados nela acabando com a qualidade ou seja,potabilidade,para deixar os alunos mais interessados e com ânimo (...)".

Os pesquisadores em QA, QAG, EA e EQ julgam importante, a abordar a legislação que garante a potabilidade da água a todo cidadão e também, questões relativas a atitudes de responsabilidade em relação à contaminação dos rios e oceanos. Os pesquisadores em EA, QAG e EQ consideram importante tratar a qualidade não como exemplificação, mas como o próprio objeto de estudo.

O professor P5 aborda os conceitos floculação, decantação, filtração, transformações químicas e funções inorgânicas, através do tratamento da água.

Os pesquisadores de QA, EA e EQ julgam importante a abordagem do custo do tratamento da água para a sociedade. No entanto, estes aspectos não são explorados por P5, pois utiliza a água como um meio para ensinar alguns conceitos científicos. Segue o relato:

P5: “(...) utilizo o data show mostrando todas as etapas do tratamento da Sabesp e vou explicando na lousa as transformação químicas e as funções(...) as transformações químicas que ocorrem na floculação é para retirar as partículas sólidas pequenas que ficam na água após a 
peneiração, o sulfato de alumínio que é um sal e o hidróxido de cálcio que é uma base reagem formando um sólido branco que depois decanta arrastando partículas sólidas que estão presentes na água, depois temos a filtração que separa o precipitado do líquido(...) depois eu levo eles no laboratório realizamos a floculação, a decantação e a filtração(...) depois eles respondem uma questão como: Explique todas as etapas do tratamento. Escreva a transformação química que ocorre na floculação(...)".

De acordo com os conceitos mencionados pelos pesquisadores em EQ, figura 3, atribuem uma grande importância a: propriedades, ligações química, reações e soluções. Como se pode verificar na figura 17, P5 não menciona tratar propriedades e soluções.

O P5 mencionou que algumas vezes, participa de um projeto interdisciplinar sobre a qualidade da água, envolvendo professores de várias disciplinas e a comunidade. Demonstram através de cartazes com frases de conscientização a respeito da qualidade. Os pesquisadores em QA e QAG julgam importante este tipo de abordagem, e ainda os pesquisadores em QA, EQ, QAG e EA consideram importantes a questão das atitudes Segue o relato:

P5: “(...) nós realizamos um projeto de preservação, conservação e valorização da qualidade da água com a disciplina de geografia, biologia e química é para a comunidade não tratamos conceitos os aluno constroem frases como: não jogue lixo no rio, sem qualidade não existe vida marinha, o lixo contamina as águas subterrâneas, com o objetivo de atingir a comunidade para que eles desenvolvam atitudes de valorização e conscientização com a água (...)".

O professor apresenta uma visão naturalista, pois explica o tratamento através de descrição conceitual, e também uma visão social e conservadora quando trata atitudes.

O tratamento dado por P5 a água, pode-se comparar com a visão dos pesquisadores em QA, EA e QAG, conforme apresentado na trama de conteúdos da figura 18. 


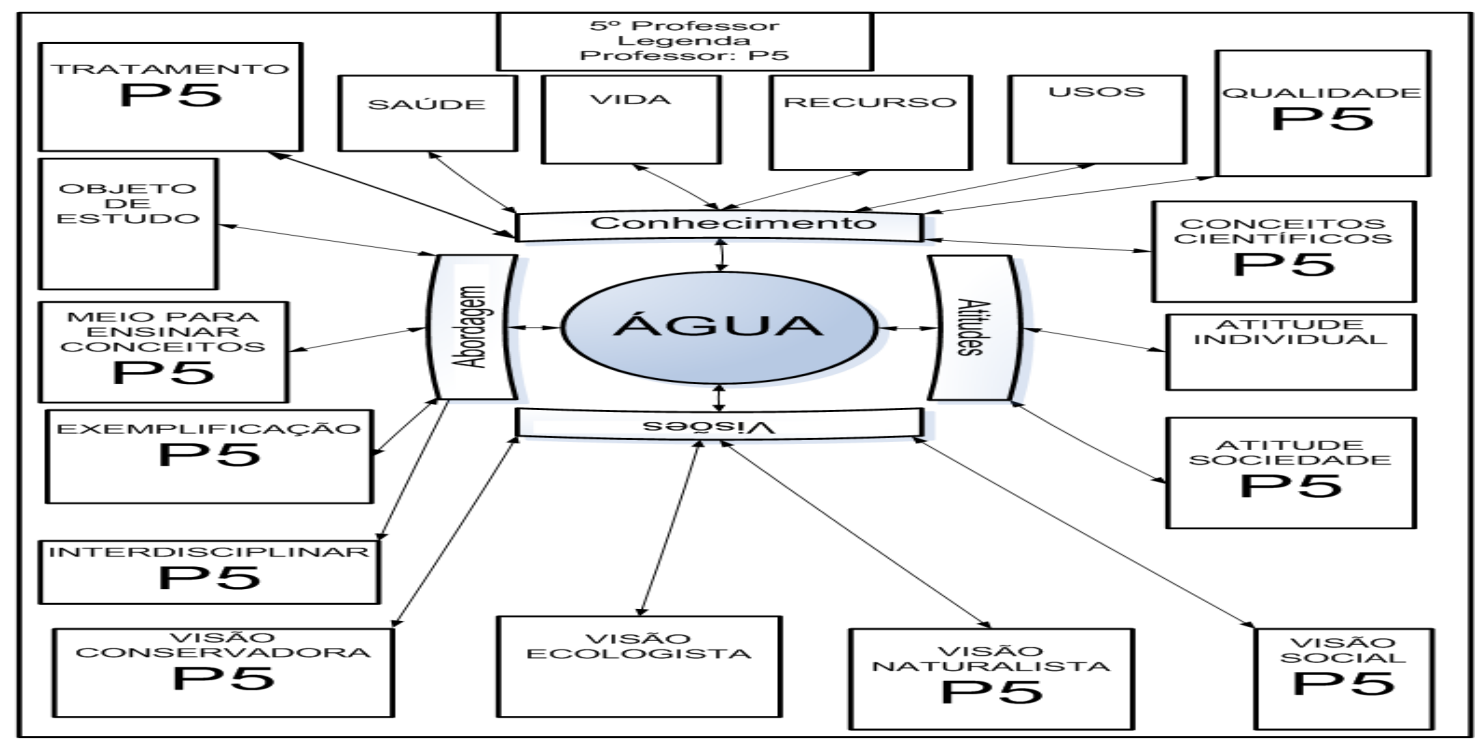

Figura 18. Trama de conteúdos (P5).

A abordagem do P5 está relacionada à categoria possibilidade discutida pelos pesquisadores em EQ em apenas um momento, quando aborda a qualidade através de um projeto interdisciplinar. No entanto, sua abordagem está fortemente ligada à descrição conceitual e exemplificações. Com relação à visão dos pesquisadores em EQ, a figura 19, mostra a realidade e possibilidade do P5.

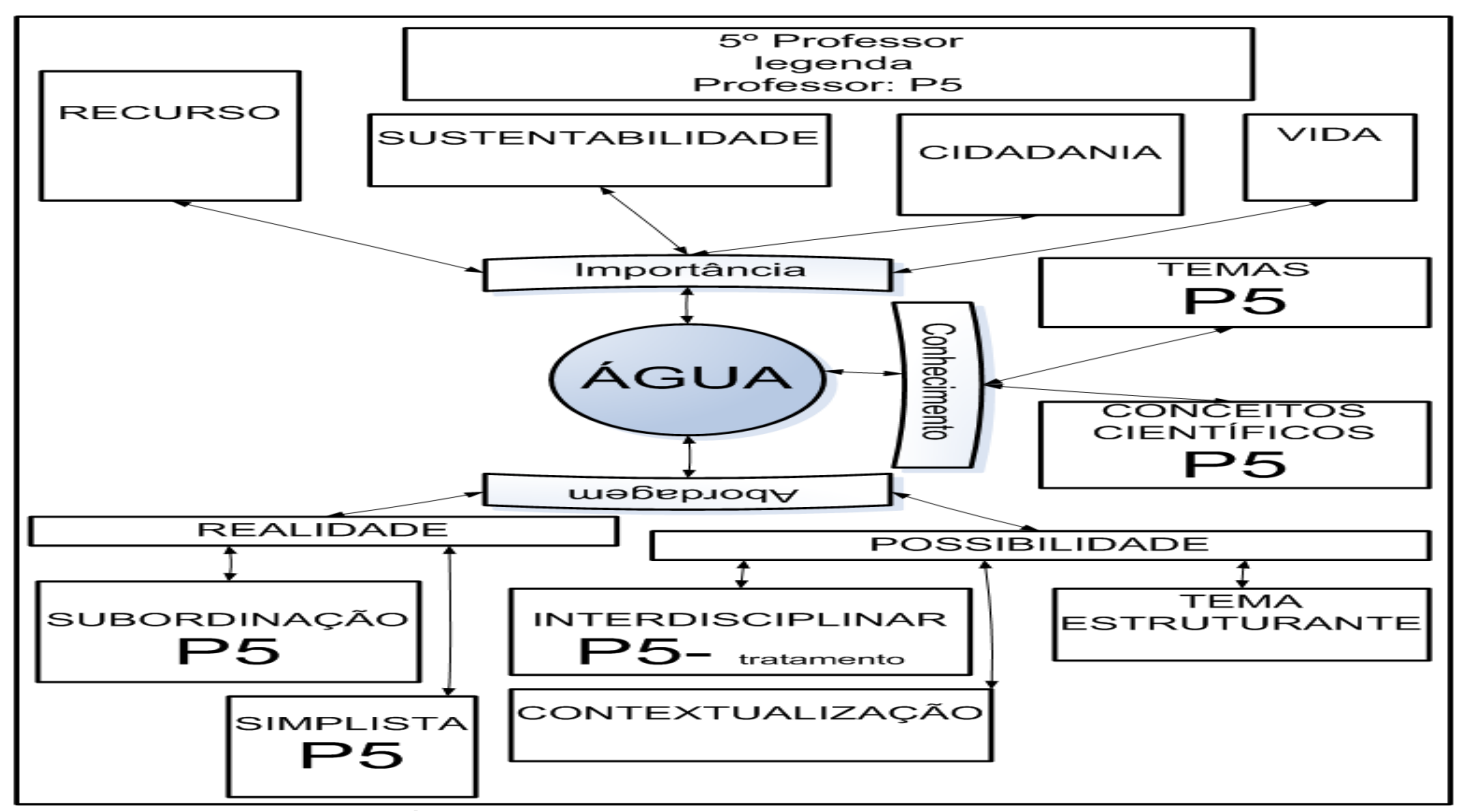

Figura 19. Trama de conteúdos (P5). 
A abordagem do P5 está relacionada à categoria possibilidade discutida pelos pesquisadores em EQ em apenas um momento, quando aborda a qualidade através de um projeto interdisciplinar. No entanto, sua abordagem está fortemente ligada à descrição conceitual e exemplificações. Com relação à visão dos pesquisadores em EQ, a figura 19, mostra a realidade e possibilidade do P5.

Considerando os temas apontados como importantes no ensino pelos pesquisadores em EQ figura 4, podemos verificar que o uso e o ciclo não são mencionados por P5 ( vide figura 17). Assim, podemos considerar que P5 está pouco contribuindo para que seus alunos e comunidade possam ter conhecimento, a respeito do uso da água, de maneira responsável. Este professor, não julga muito importante o tratamento de atitudes no Ensino de Química.

O P6 aborda os temas: ciclo, qualidade, tratamento e recurso. Trata também, alguns conceitos científicos, aborda a água através de metodologias de ensino diversificadas. A relação entre os conteúdos tratados e a abordagem dada está evidenciada no mapa conceitual figura 20 , elaborado pela pesquisadora.

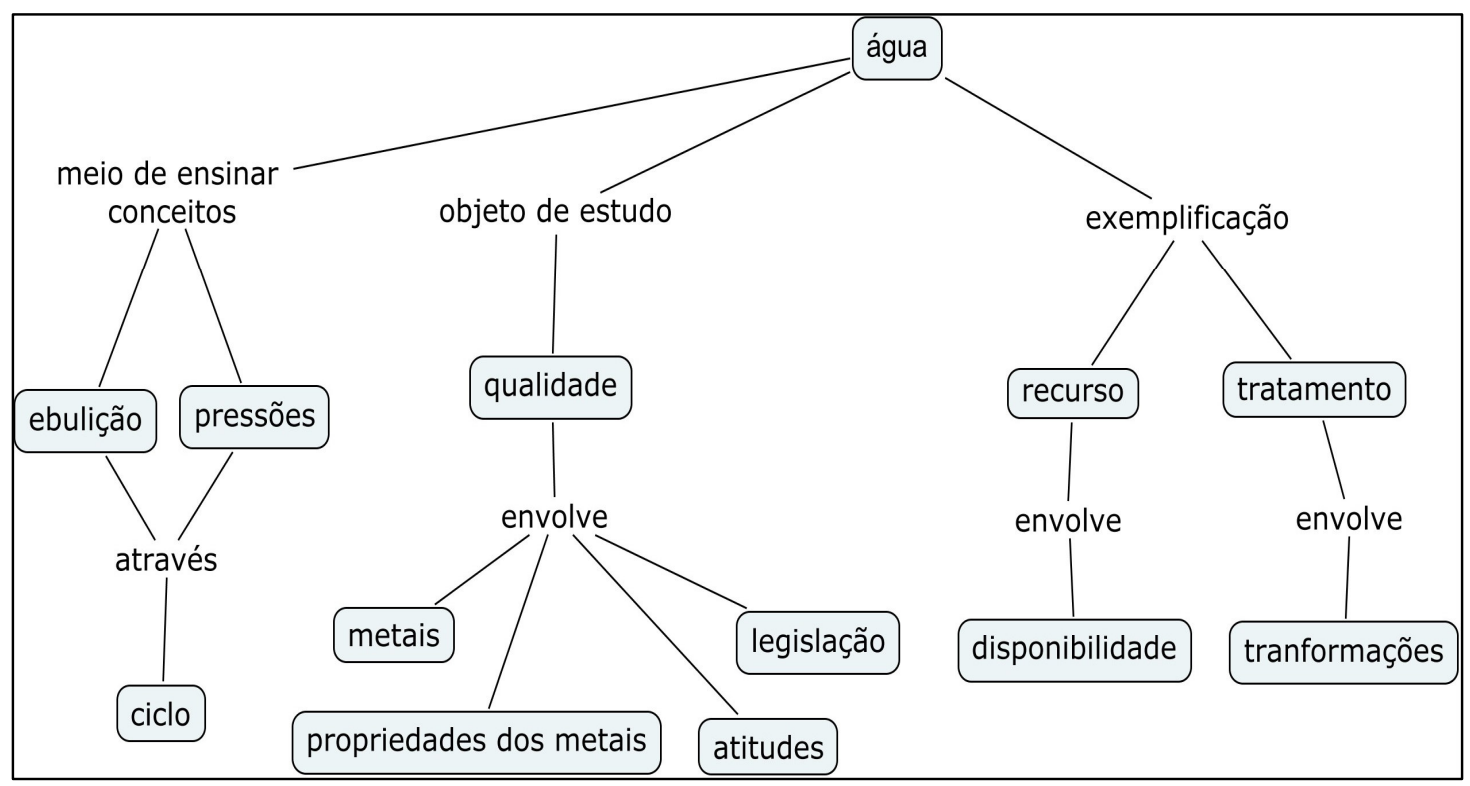

Figura 20. Mapa conceitual das idéias do (P6) sobre os conteúdos tratados e como os aborda.

O professor P6 aborda os conceitos de ebulição e pressão, utilizando 0 ciclo da água como meio para ensinar os conceitos científicos. Segue o relato:

P6: "(...) explico o ciclo da água, explico que no nível do mar a altitude é menor a água entra em ebulição a $100 C^{\circ}$, já no interior a altitude é maior que a do nível do mar sendo a pressão 
menor sendo assim á água ferve a temperaturas inferiores a $100 C^{\circ}$, coloco na lousa as altitudes e as pressões, quanto maior a altitude do local, menor a pressão atmosférica e menor a temperatura de ebulição( água do estado liquido para o gasoso(...)eu trago fotos de várias cidades eu tiro da internet, monto um painel em um isopor e levo em cada sala, fotos do litoral e de outras cidades como Belo Horizonte, Cuiabá, Teresina, São Paulo, Brasília, Manaus e o mar Cáspio na Ásia (...)eu peço para escolherem um local e explicar o porque da temperatura de ebulição. Eles realizam um gráfico PxT, eu trago papel quadriculado e régua eles entregam como atividade (...)".

A abordagem do P6 nos remete a pesquisa de Osborne e Cosgrove (1983) pois, relatam, que os alunos apresentam concepções sobre o ciclo da água que estão distantes do conhecimento científico, ou seja, dos conceitos como: molécula, íons, átomos, substância, variação de temperatura e cinética química, pois estes conceitos não estão sendo abordados pelos professores no ensino de ciências e química.Os pesquisadores em EA, QAG e EQ consideram importante tratar o ciclo não como um meio, mas como o próprio objeto de estudo.

Por outro lado a água torna-se foco central do estudo, quando P6 aborda em suas aulas a qualidade da água. Além de explicar o conceito de metais e suas propriedades físicas e químicas, também aborda os padrões de potabilidade vigentes na legislação brasileira.. Segue o relato:

P6: "(...) eu explico que algumas empresas jogam resíduos de processo que contém chumbo, cádmio e mercúrio, estes são metais pesados que o metabolismo humano e animal não utilizam, causando várias doenças (...) eu ensino na lousa os elementos químicos os metais pesados suas características físicas e químicas(...) então trago a legislação da Sabesp uma cópia para cada aluno (...) e explico que água dos mananciais passa por analise, obedece a padrões é lei, para identificar metais pesados prejudicam a vida marinha e ao homem causam doenças como $o$ câncer (...)solicito que escrevam as características físicas do mercúrio e quais os impactos ambientais que são causados através deste metal(...)

De acordo com os conceitos representados pelos pesquisadores em EQ, figura 3, atribuem uma grande importância a: propriedades, ligações química, reações e soluções. Como se pode verificar na figura 20, P6 não menciona tratar ligações e soluções.

Também, aborda atitudes de conservação e proteção, através de fotos de indústrias que lançam efluente nos rios sem tratamento. Segue o relato:

P6: “(...) trago fotos de várias indústrias que não estão preocupadas com a qualidade dos mananciais então lançam resíduos de processo que contem chumbo, cádmio e mercúrio(...) explico 
isso para eles para que eles tenham consciência e tenham atitudes de proteger e conservar a água, quando eles vêem estas fábricas de fundo de quintal que lançam resíduos sem tratamento tem que denunciar a órgãos competentes, ele tem que ser um protagonista se envolver com a situação, (...)coloco questões perguntando assim: Você já viu uma situação igual a desta empresa que não trata o esgoto? Quais foram suas atitudes? Depois desta aula você mudaria suas atitudes?(..,)".

Entretanto, P6 aborda a qualidade da água como um objeto de estudo, ou seja, um tema gerador, tratando conceitos, política e atitudes, como relata à nova proposta para o ensino de Química (SÃO PAULO, 2008).

Os pesquisadores em QA, QAG, EA e EQ julgam importante, a abordagem da qualidade da água e atitudes.

O professor P6 trata de maneira exemplificada o recurso água no planeta, comentando apenas sua distribuição. Também, aborda o tratamento da água, citando somente uma transformação química que ocorre na etapa da floculação. Segue o relato:

P6: “(...) ensino então sobre a porcentagem da distribuição da água no estado líquido e solido, é comento o exemplo do livro, rapidamente (...)então falo das transformações químicas faço a reação do sulfato de alumínio e só, faço um comentário falo que a Sabesp trata a água nãocobro atividades e exercícios e avaliações (...)"

Os pesquisadores em QA, EA e EQ julgam importante, a abordagem de todas as etapas do tratamento e o custo para a população, e apontam também, que a água deve ser tratada como sendo um recurso natural e finito. Os pesquisadores em QA, EA, QAG e EQ apontam a importância de tratar atitudes.

Em relação à visão ambientalista, o P6 apresenta um enfoque naturalista, quando trata as propriedades da água, sua preocupação é a descrição conceitual.

Apresenta uma visão social, conservadora e ecologista (Lago e Pádua, 1989), quando aborda atitudes e a legislação, que garante a potabilidade da água. O tratamento dado por P6 a água, pode-se comparar com a visão dos pesquisadores em QA, EA e QAG, conforme apresentado na trama de conteúdos da figura 21. 


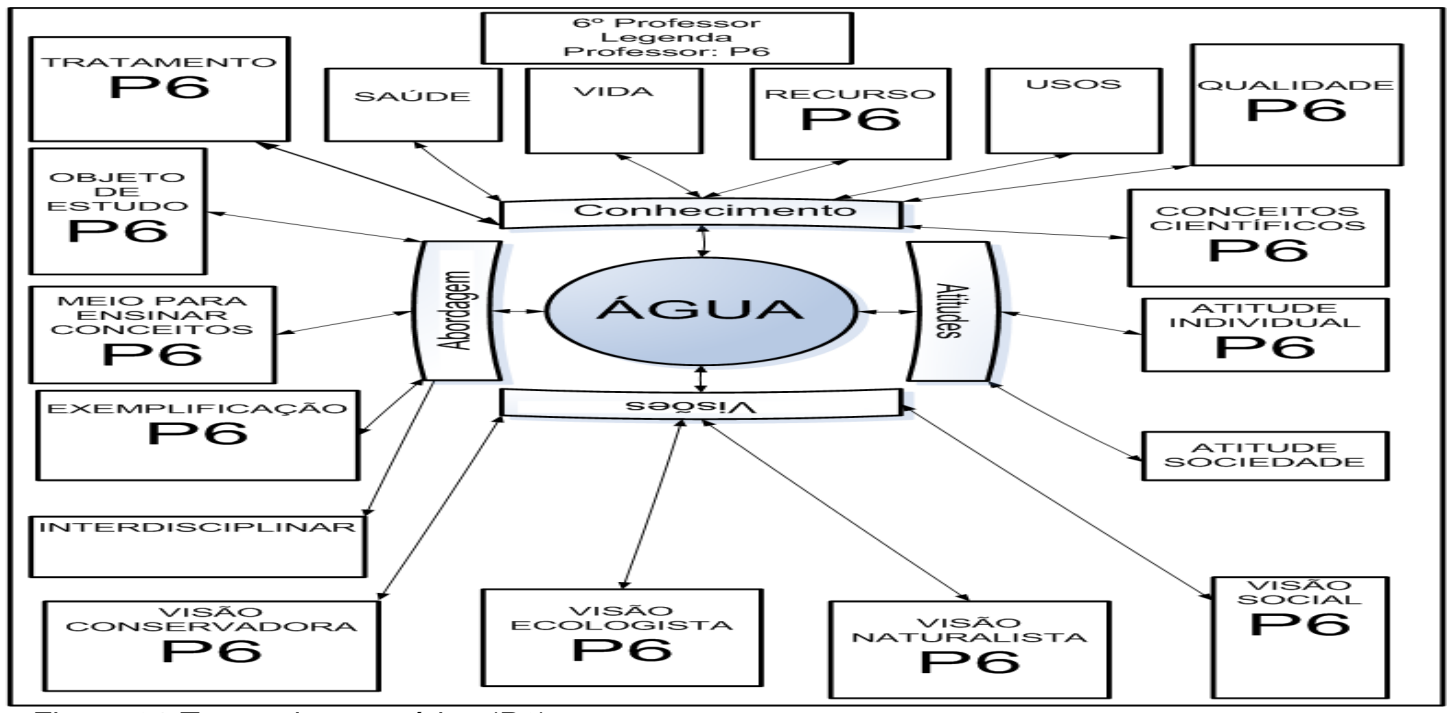

Figura 21. Trama de conteúdos (P6).

A abordagem do P6 está relacionada à categoria realidade, discutida pelos pesquisadores em EQ, pois sua abordagem está predominantemente ligada à subordinação conceitual e exemplificações, sendo que não contempla a temática da água como objeto de estudo. Sua abordagem está ligada à categoria possibilidade, penas quando aborda a qualidade da água de maneira contextualizada. Com relação à visão dos pesquisadores em EQ na figura 22, mostra a realidade e a possibilidade do P6.

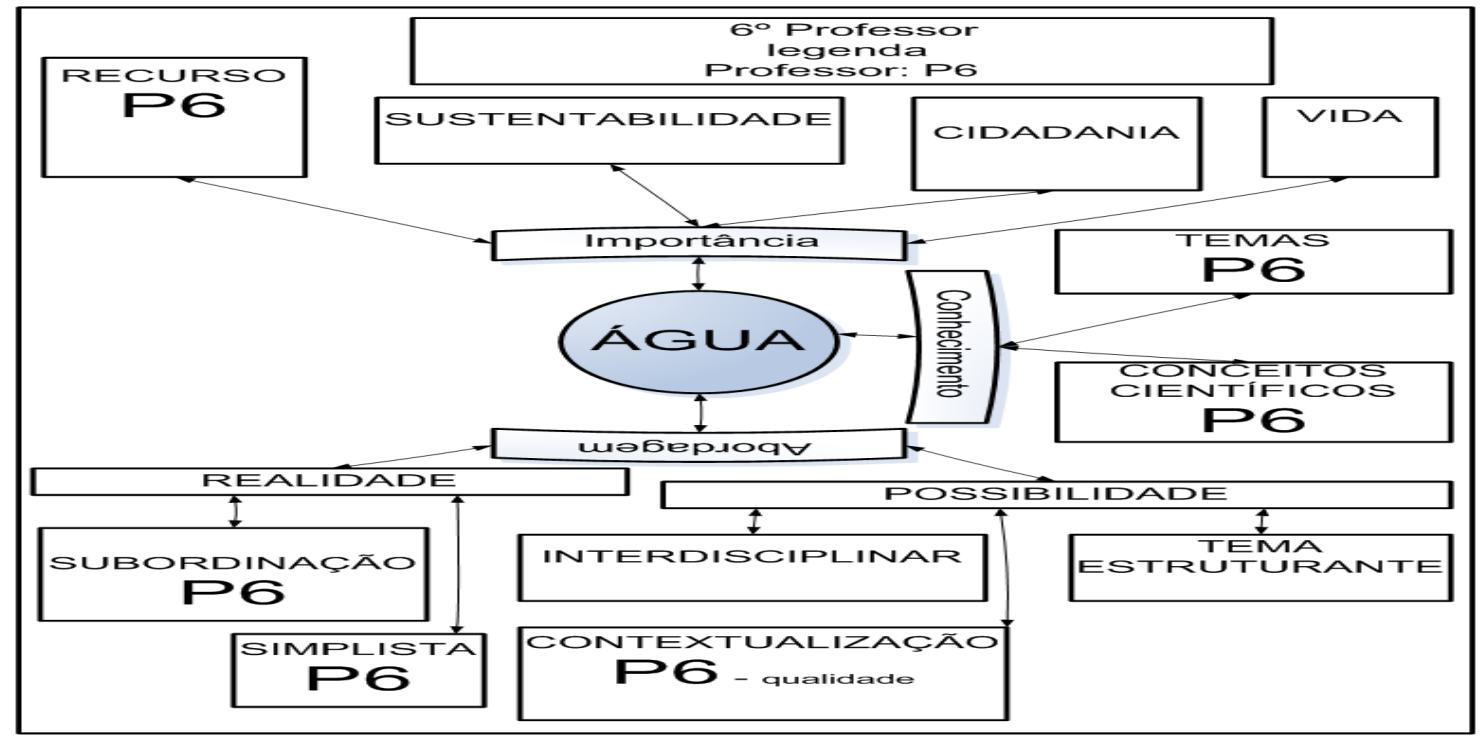

Figura 22. Trama de conteúdos (P6).

Analisando os temas apontados como importantes no ensino pelos pesquisadores em EQ figura 4, podemos verificar que o uso não é mencionado por P6 ( vide figura 20). Assim, podemos considerar que P6 não trata a água sendo um 
recurso natural, fundamental a vida do homem e animais. Também, quando aborda o tratamento não discute com os alunos, atitudes de valorização, respeito e conservação. Colaborando assim, para que o aluno do Ensino Médio tenha uma visão limitada sobre a água.

O P7 aborda os temas: qualidade, tratamento e condutibilidade elétrica, trata também, alguns conceitos científicos, aborda a água através de metodologias de ensino diversificadas. A relação entre os conteúdos tratados e a abordagem dada está evidenciada no mapa conceitual figura 23 , elaborado pela pesquisadora.

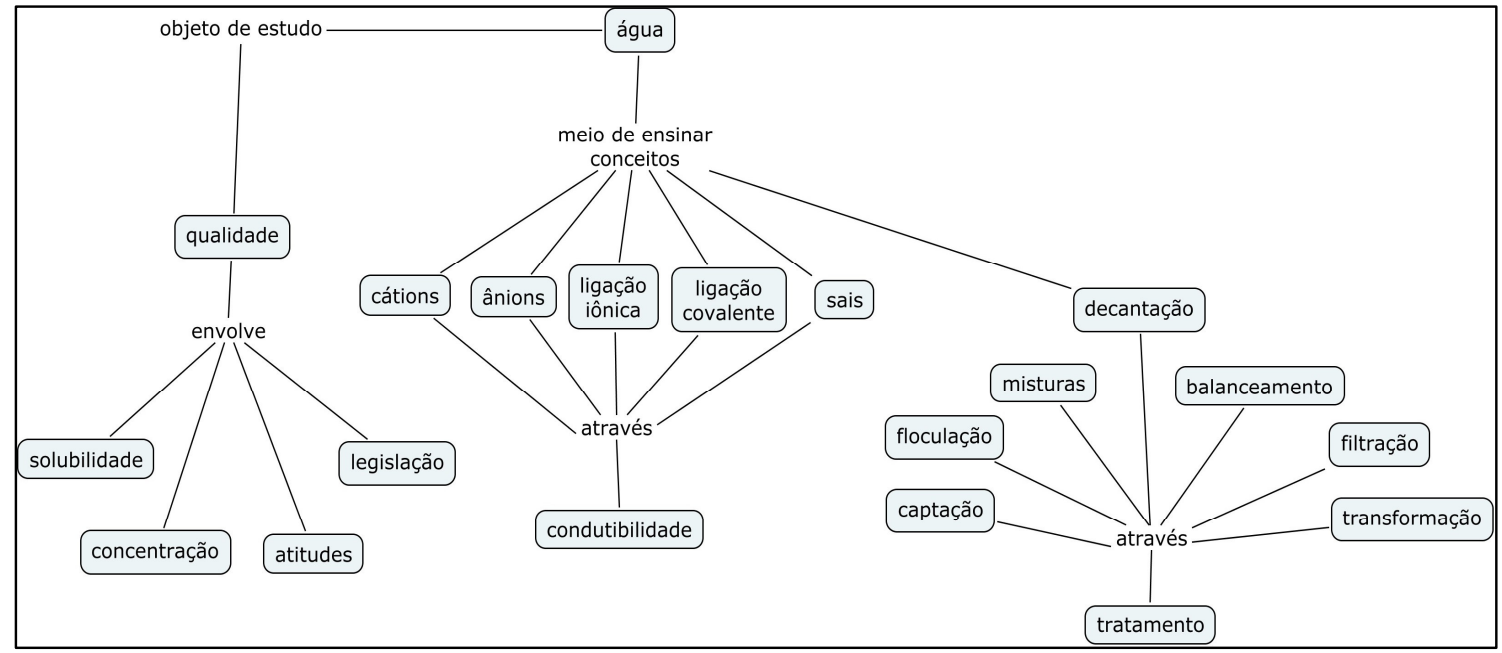

Figura 23. Mapa conceitual das idéias do (P7) sobre os conteúdos tratados e como os aborda.

Para este professor P7, a água torna-se o foco principal do estudo, quando aborda a qualidade em suas aulas, através do rótulo da água mineral, ensina os padrões de potabilidade, solubilidade e concentração. Segue o relato:

P7: "(...) explico os parâmetros da qualidade, peço para o aluno trazer um rótulo de água, explico que para o consumo humano a água deve obedecer alguns parâmetros que fazem parte de uma legislação que garante a potabilidade (...) explico que os valores do rótulo fazem parte de uma legislação, uma lei que determina a potabilidade da então explico detalhadamente a turbidez pois são duas aulas não consigo explicar todos parâmetros,são partículas sólidas em suspensão que não solubilizam que podem ser provocados pelos metais como: zinco, ferro, manganês e plásticos que estão presentes nos resíduos industriais que muitas vezes atingem os mananciais(...) explico a solubilidade, concentração massa / volume na lousa,também explico que a turbidez são partículas sólidas em suspensão que não solubilizam, realizamos exercícios(...)".

Também, propõem um debate sobre o alto índice de turbidez nos mananciais, com o objetivo de abordar atitudes de conservação e zelo. Segue o relato: 
P7: “(...) na próxima aula debatemos em grupo algumas questões para entregar (...) Por que atualmente os mananciais possuem alto índice de turbidez? $O$ aluno pode contribuir com a redução da turbidez? Como? Você pode beber uma água turva? Explique. Então realizamos um debate sobre as atitude de conservação, respeito, cuidado e valorização em relação a qualidade da água, que devemos pensar duas vezes antes de lançar lixo e poluir os mananciais(...)".

O P7 aborda a qualidade da água como um tema gerador, priorizando os conceitos científicos, legislação e as atitudes de conservação e zelo, possibilitando ao aluno o entendimento entre as interações da ciência na sua realidade social, favorecendo o desenvolvimento de atitudes conscientes e responsáveis em relação à potabilidade da água. Delizoicov et. al; (2002) relata que os temas geradores têm como princípios básicos: uma visão ampla do cotidiano; e uma postura critica do professor. Os pesquisadores em QA, QAG, EA e EQ julgam importante a abordagem da qualidade e atitudes.

O P7 aborda os conceitos cátions, ânions, ligações iônicas, covalentes e os sais, utilizando a condutibilidade elétrica da água, como um meio para ensinar os conceitos científicos. Segue o relato:

P7: “(...) Na primeira aula realizo um experimento no laboratório com o aparelho de condutibilidade elétrica que cada grupo constrói (com lâmpadas e fios desencapados e uma tomada) eles observam que a destilada não conduz corrente, pois é isenta de sais, a potável conduz (...) depois explico o conceito de íons utilizo isopor e bolinhas eu compro e levo em cada sala, para cada camada vou anexando bolinhas para representar os elétrons da ultima camada:cloreto, potássio, cobre, iodeto, enxofre, sódio explico os cátions e ânions através dos íons recebendo e doando bolinhas, depois a ligação covalente e iônica no isopor com as bolinhas coloridas para identificar quem está doando e recebendo, faço a ligação que ocorre nos sais: cloreto, potássio, cobre, iodeto, enxofre, sódio, realizamos exercícios, assim eles entendem os conceitos presentes na água(...)".

Quando o P7 aborda a condutibilidade elétrica, através de um experimento, sua priorização é ensinar os conceitos científicos, é uma experimentação tradicional, não existem questões que possibilite o aluno a questionar e refletir sobre 0 experimento e os conceitos envolvidos. A importância da inclusão da experimentação química no ensino médio está no seu papel investigativo, em auxiliar o aluno na compreensão dos fenômenos relacionados a água sobre os quais se referem aos conceitos químicos (GEPEQ, 2005).

Os pesquisadores em EQ julgam importante a abordagem da condutibilidade elétrica da água. 
Também, aborda captação, decantação, floculação, filtração e a transformação química, misturas heterogêneas e balanceamento, utilizando as etapas do tratamento da água como um meio para ensinar conceitos científicos. Segue o relato:

P7: “(...) eu ensino as etapas que são extremamente importantes: captação, decantação a mistura é heterogênea então ocorre duas fases, floculação ocorre as transformações químicas, reagente e produto formado e também o balanceamento por tentativa, pois adicionamos o sulfato de alumínio e hidróxido de sódio que vai precipitar(...) o aluno tem um estudo completo são 3 páginas na apostila da escola , eu amplio o desenho novamente na lousa com giz colorido para ficar claro para o aluno a explicação, (...) solicito atividade para entregar, como: Explique cada etapa do tratamento? Escreva as reações químicas (...)".

No tratamento da água sua prioridade são os conceitos, não existe preocupação com a alfabetização científica, ou seja, a abordagem das tecnologias envolvidas, benefícios para a comunidade e o desenvolvimento de atitudes de valorização.

Os pesquisadores de $\mathrm{QA}$, EA e EQ também julgam importante a abordagem do tratamento e o custo para a sociedade, e também, os pesquisadores em QA, EA, QAG e EQ julgam importante o tratamento de atitudes de valorização.

De acordo com os conceitos citados pelos pesquisadores em EQ figura 3, atribuem uma grande importância a: propriedades, ligações química, reações e soluções. Como se pode verificar na figura 23 , P7 não menciona tratar as propriedades.

Este professor apresenta visão naturalista, visão social e conservadora, pois trata atitudes de valorização e conservação em relação aos mananciais, e uma visão ecologista quando aborda os parâmetros de qualidade da água. $O$ tratamento dado por P7 a água, pode-se comparar com a visão dos pesquisadores em QA, EA e QAG, conforme apresentado na trama de conteúdos da figura 24. 


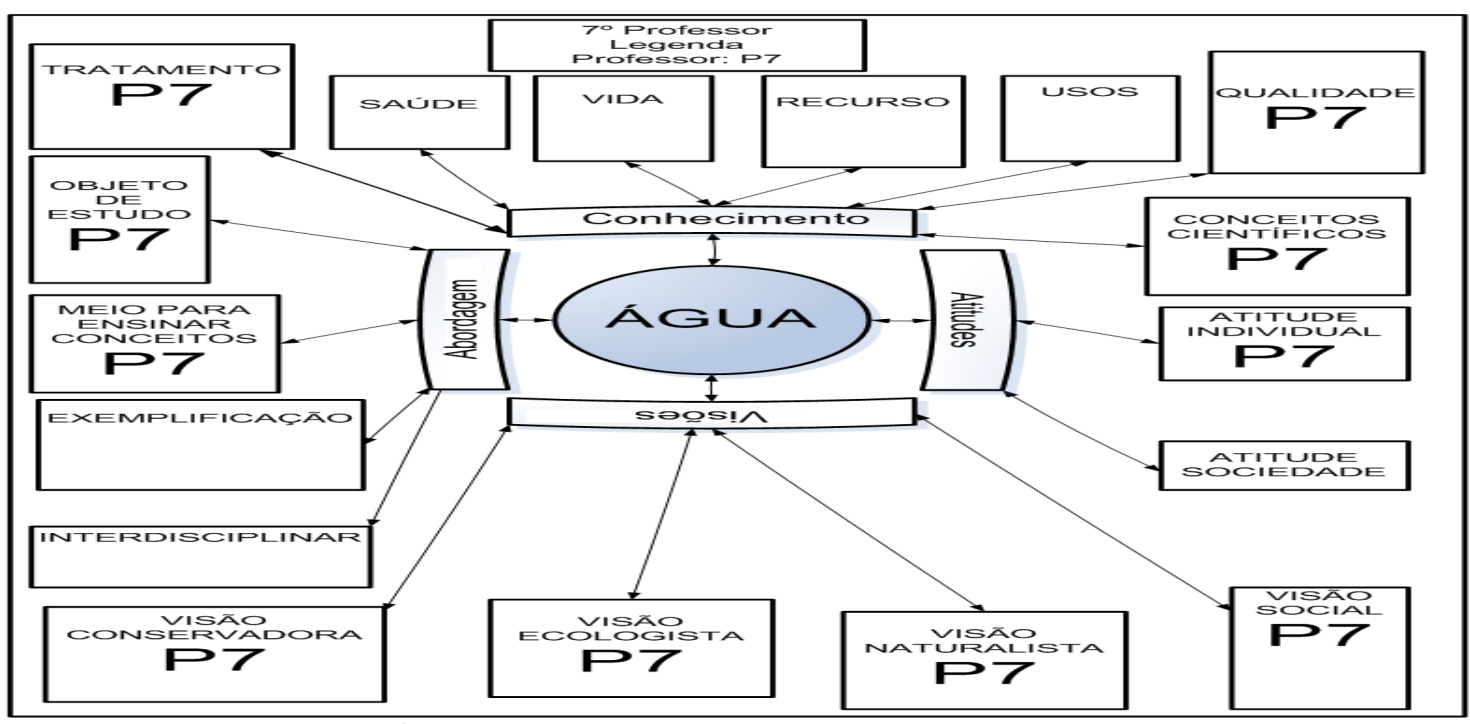

Figura 24. Trama de conteúdos (P7).

A abordagem do P7 está relacionada à categoria realidade discutida pelos pesquisadores em EQ, pois está preso a uma forte organização e subordinação conceitual, tendo uma visão bastante simplista. Apenas em um momento trata a qualidade da água de maneira contextualizada. Com relação à visão dos pesquisadores em EQ, a figura 25, mostra a realidade e possibilidade do $\mathrm{P} 7$.

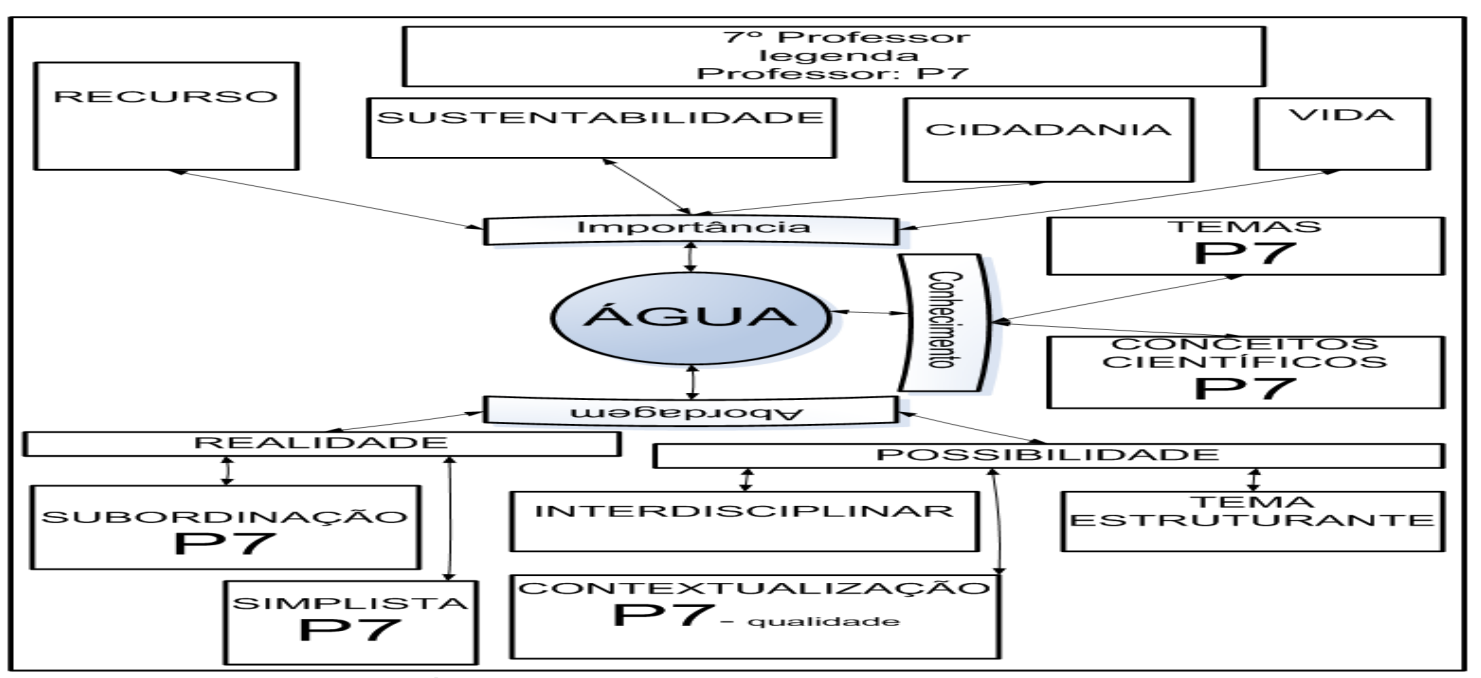

Figura 25. Trama de conteúdos (P7).

Considerando os temas apontados como importantes no ensino pelos pesquisadores em EQ figura 4, podemos verificar que o ciclo e uso não são mencionados por P7 figura 23. O tratamento, embora tenha sido mencionado, é apenas um facilitador para o tratamento de conceitos científicos. Portanto, podemos considerar que P7 está pouco contribuindo para que seus alunos possam ter 
conhecimentos que permitam uma visão ampla e crítica sobre a problemática da água.

O P8 aborda os temas: qualidade, tratamento, recurso, uso e o ciclo trata também, alguns conceitos científicos, aborda a água através de metodologias de ensino diversificadas. A relação entre os conteúdos tratados e a abordagem dada está evidenciada no mapa conceitual figura 26 , elaborado pela pesquisadora.

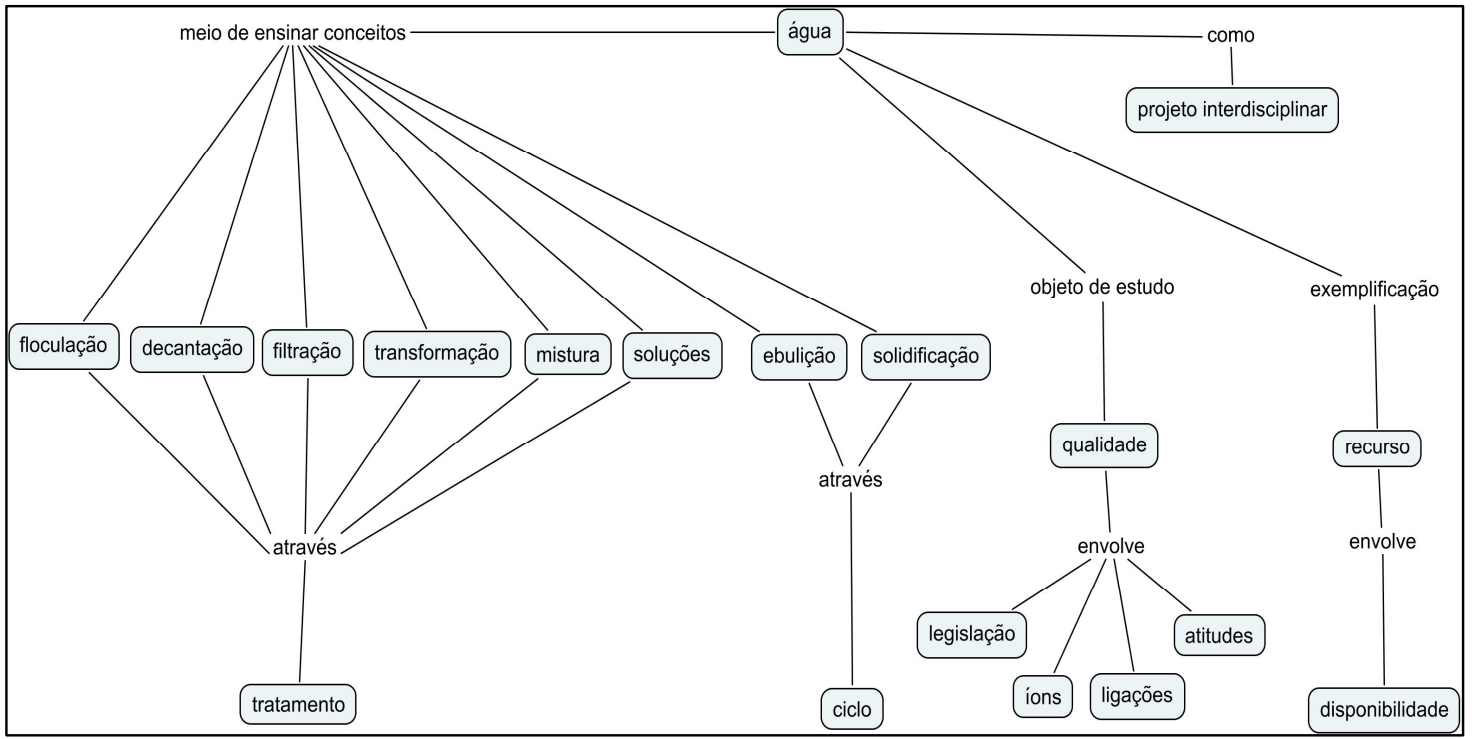

Figura 26. Mapa Conceitual das idéias do (P8) sobre conteúdos tratados e como aborda.

O professor P8 aborda os conceitos: floculação, decantação, filtração, transformações químicas, misturas e soluções, utilizando o tratamento da água como um meio para ensinar conceitos científicos. Segue o relato:

P8: "(...) quando eu explico o conceito de misturas e soluções com a decantação, e a transformação na floculação com a reação na lousa envolvendo o sulfato de alumínio,e a filtração simples depois trabalhamos com exercícios no caderno logo após eu peço para construir uma maquete com uma mini estação de tratamento de água da Sabesp com as etapas filtração, floculação, decantação e adição de cloro e flúor, então explico novamente, e peço para eles explicarem também, os conceitos em cada etapa eles apresentam a todos da escola, assim eles entendem os conceitos envolvidos(...)".

Os pesquisadores em QA, EA e EQ também julgam importante, a abordagem do tratamento e o custo para a sociedade, e também, os pesquisadores em $Q A, E A, Q A G$ e EQ julgam importante o tratamento de atitudes de valorização.

Também aborda os conceitos: ebulição e solidificação, utilizando o ciclo da água como um meio para ensinar conceitos científicos. Segue o relato: 
P8: "(...) eu construo e amplio na lousa os gráficos de mudança de estado líquido- vapor e líquido para o sólido, meu objetivo é que eles entendam como ocorre a mudança de estado, as diferenças de temperatura depois eu trago papel quadriculado e cada aluno constrói o seu gráfico e entrega como atividade, depois em grupo eles constroem o gráfico em uma cartolina e expões na escola (...)".

O P8 prioriza o ensino de apenas dois conceitos científicos, a ebulição e solidificação, quando aborda o ciclo, que de acordo com o pesquisador Bar ( 1989), os estudantes por desconhecerem muitos conceitos como variações de pressão, altitude e temperatura, apresentam concepções errôneas sobre a ebulição da água.

Os pesquisadores em EA, QAG e EQ consideram importante tratar o ciclo não como um meio, mas como o próprio objeto de estudo.

Por outro lado, a água torna- se foco central do estudo, quando P8 aborda em suas aulas a falta de qualidade dos lençóis freáticos. Além de explicar os conceitos: íons e ligações químicas, também discute a legislação da potabilidade. Segue o relato:

P8: "(...) eu desenho uma plantação na lousa e ao lado coloco os fertilizantes que são lançados e que sua composição contem íons de nitrato e fosfato, desenho os lençóis freáticos e explico que estes íons são arrastados pela irrigação e pelas chuvas para os lençóis subterrâneos , então explico que quando os fertilizantes em uma lagoa causam um grande crescimento de algas, isolando a água do oxigênio do ar, com falta de oxigênio o peixe não sobrevive nos lagos (...), explico que a água para ser potável deve respeitar os parâmetros da legislação brasileira, eu trago os padrões que retiro do site da Sabesp, utilizo transparências com fotos de regiões de Rio Preto e Novo Horizonte que utilizam grandes quantidades de agrotóxico nas plantações, então explico o que é um íon, os cátions e ânions faço a distribuição eletrônica do nitrogênio, fósforo e do oxigênio, explico quem doa e recebe faço na lousa, depois explico a ligações químicas que ocorrem entre eles (...) realizamos exercícios sobre as ligações iônicas(...) eu peço uma pesquisa sobre 5 cidades do interior de São Paulo que utilizam a maior quantidade de agrotóxicos em suas plantações(...)".

Também, este professor após o desenho e as transparências, aborda as mudanças de atitudes dos agricultores através de questões e discussões. Segue o relato:

Então discutimos sobre a atitude de irresponsabilidades dos agricultores com a vida aquática, e se poderia existir mudança de atitudes, utilizar outros agrotóxicos ou diminuir as concentrações no uso (...) então na sala discutimos que o próprio agricultor ao mesmo tempo que cultiva o alimento, polui e destrói o recurso vital água com atitudes irresponsáveis (...)então coloco algumas questões como: Os agricultores têm uma parcela no índice de mortalidade da vida aquática? Quais são as atitudes que eles poderiam mudar, de modo a contribuir com a vida aquática 
e valorizar e conservar a qualidade da água (...)

Trata a qualidade da água nos lençóis freáticos como um tema gerador, possibilitando o ensino de conceitos, os agrotóxicos derivados de tecnologias que visam proteger as plantações contra as pragas, o impacto ambiental com a escassez da qualidade nos mananciais, e uma nova postura nas atitudes dos agricultores. Como se pode perceber pelo relato do professor, a ênfase é dada à atitude de outros, parecendo isentar o aluno de responsabilidade, de considerar suas próprias ações. Assim, embora a problemática seja relevante, consideramos que o P8 perdeu uma oportunidade de abordar de maneira sistêmica, deixando de favorecer a construção por parte do aluno, de uma visão crítica que considere a complexidade do problema e seu próprio papel nesse contexto.

Os pesquisadores em QA, QAG, EA e EQ julgam importante a abordagem da qualidade e atitudes.

O professor P8 trata de maneira exemplificada a distribuição do recurso água, no Planeta. Segue o exemplo:

P8: "(...) utilizo o livro didático e leio as porcentagens de água salgada e doce no Planeta realizo um comentário, pois o exemplo do livro é bem ilustrativo, então só comento a distribuição, não fico detalhando não vejo tanta importância é mais informativo (..) não cobro exercícios não(...)

Este professor quando aborda a distribuição do recurso água no planeta, não julga necessária uma abordagem conceitual, científica, social e ambiental, trata este tema apenas como um exemplo simples. Os pesquisadores em QA, EA e EQ julgam importante a abordagem do recurso, como sendo natural e finito.

O P8 mencionou que algumas vezes participa de um projeto interdisciplinar sobre o uso exagerado da água, envolvendo professores de várias disciplinas e os pais. Demonstram através faixas e folhetos, frases de conscientização, sobre o desperdício da água tratada, com esperança que os moradores utilizem de maneira responsável. Segue o relato:

P8: "(...) eu e a professora de biologia e os alunos construímos faixas com várias frases assim: Economize água, não fiquem lavando o quintal todos os dias, não fique 1 hora no banho, não deixe a torneira pingando (...) cuide da água, achamos que com isso os pais podem ficar sensibilizados e pensar um pouco sobre o uso inadequado da água, distribuímos também panfletos que retiramos na Sabesp sobre o desperdício (...)". 
Os pesquisadores em QA e QAG julgam importante este tipo de abordagem, e ainda os pesquisadores em QA, EQ, QAG e EA consideram importantes a questão das atitudes.

De acordo com os conceitos citados pelos os pesquisadores em EQ figura 3, atribuem uma grande importância aos conceitos: propriedades, ligações química, reações e soluções. Como se pode verificar na figura 26, P8 menciona tratar todos os conceitos.

Em relação a visão ambientalista, o P8 apresenta uma visão naturalista, pois em vários momentos descreve a água através dos conceitos científicos. Apresenta também, uma visão social, conservacionista e ecologista quando discute as atitudes e a legislação.

O tratamento dado por P8 a água, pode-se comparar com a visão dos pesquisadores em QA, EA e QAG, conforme apresentado na trama de conteúdos da figura 27.

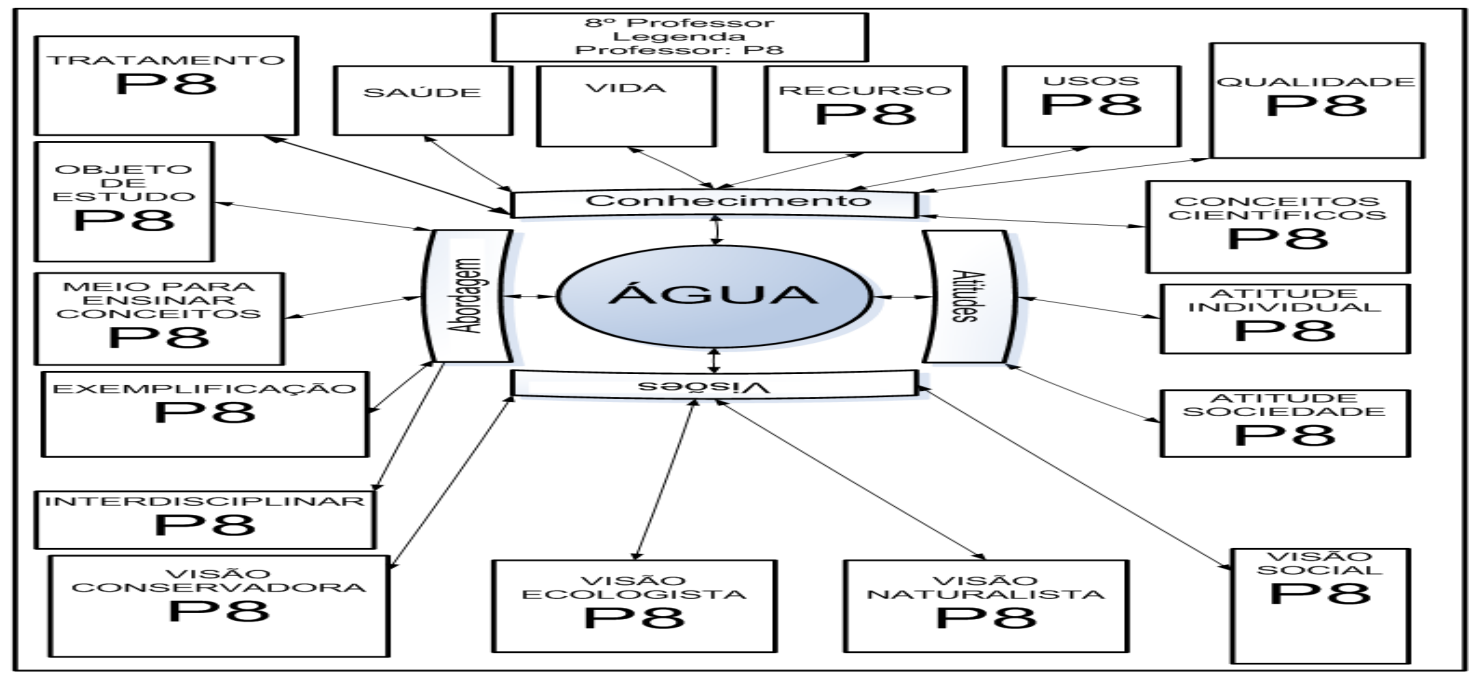

Figura 27. Trama de conteúdos (P8).

A abordagem do P8 está relacionada à categoria realidade, discutida pelos pesquisadores em EQ, pois sua abordagem está fortemente ligada à subordinação conceitual e exemplificações, sendo que não contempla a temática da água como tema estruturante. Sua abordagem está ligada à categoria possibilidade, apenas quando aborda a qualidade da água de maneira contextualizada e o uso através de um projeto interdisciplinar. 
Com relação à visão dos pesquisadores em EQ, a figura 28 demonstra a realidade e subordinação do $\mathrm{P} 8$.

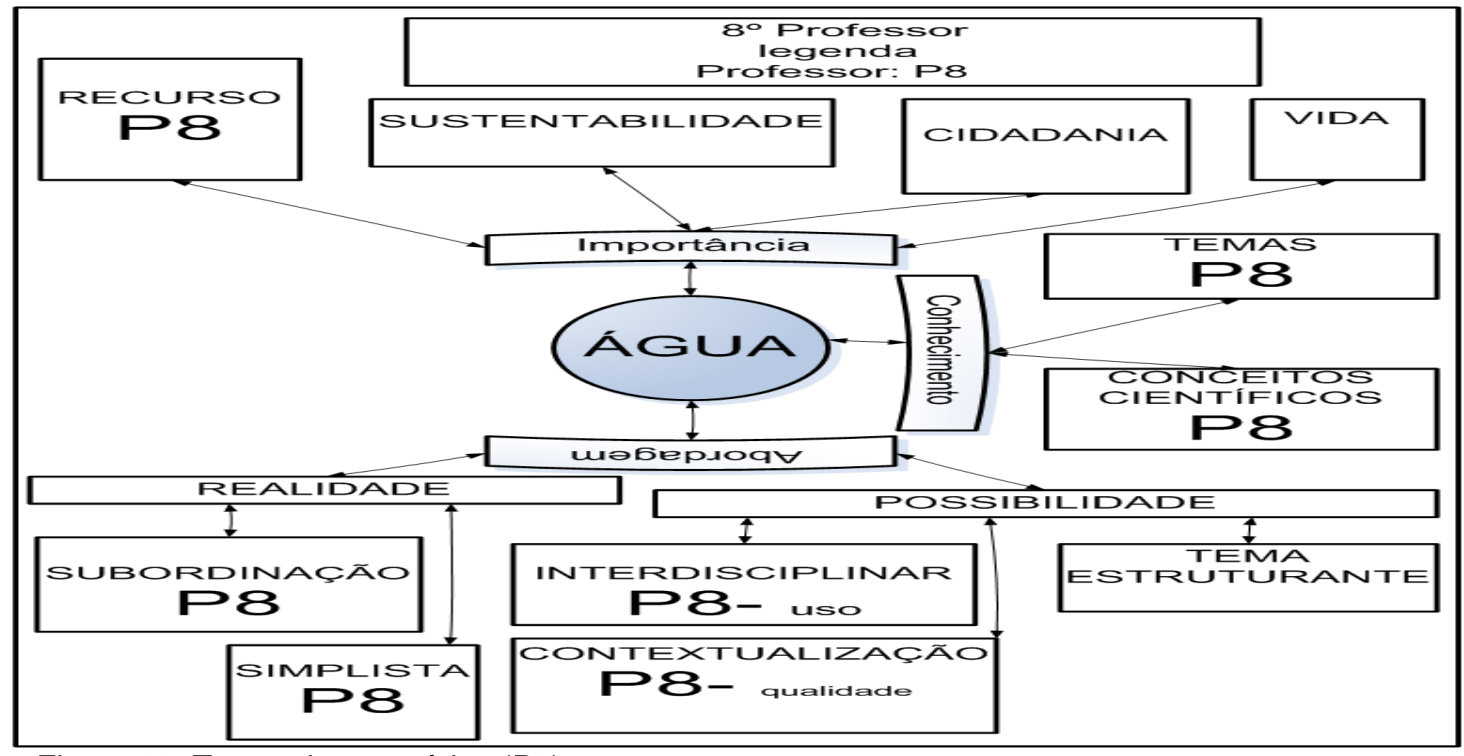

Figura 28. Trama de conteúdos (P8).

Considerando os temas apontados como importantes no ensino pelos pesquisadores em EQ figura 4, podemos verificar que o uso não é mencionado por P8 (vide figura 26), o tratamento da água é abordado apenas como um meio, para o tratamento de conceitos científicos. Como se pode perceber, este professor não julga importante tratar atitudes de conservação e respeito, em relação à água potável, não discute em nenhum momento, que a água potável é um direito de todo cidadão, seu maior enfoque, é a descrição conceitual.

O P9 aborda os temas qualidade e tratamento e também, alguns conceitos científicos, trata a água através de metodologias de ensino diversificadas. A relação entre os conteúdos tratados e a abordagem dada está evidenciada no mapa conceitual figura 29 , elaborado pela pesquisadora. 


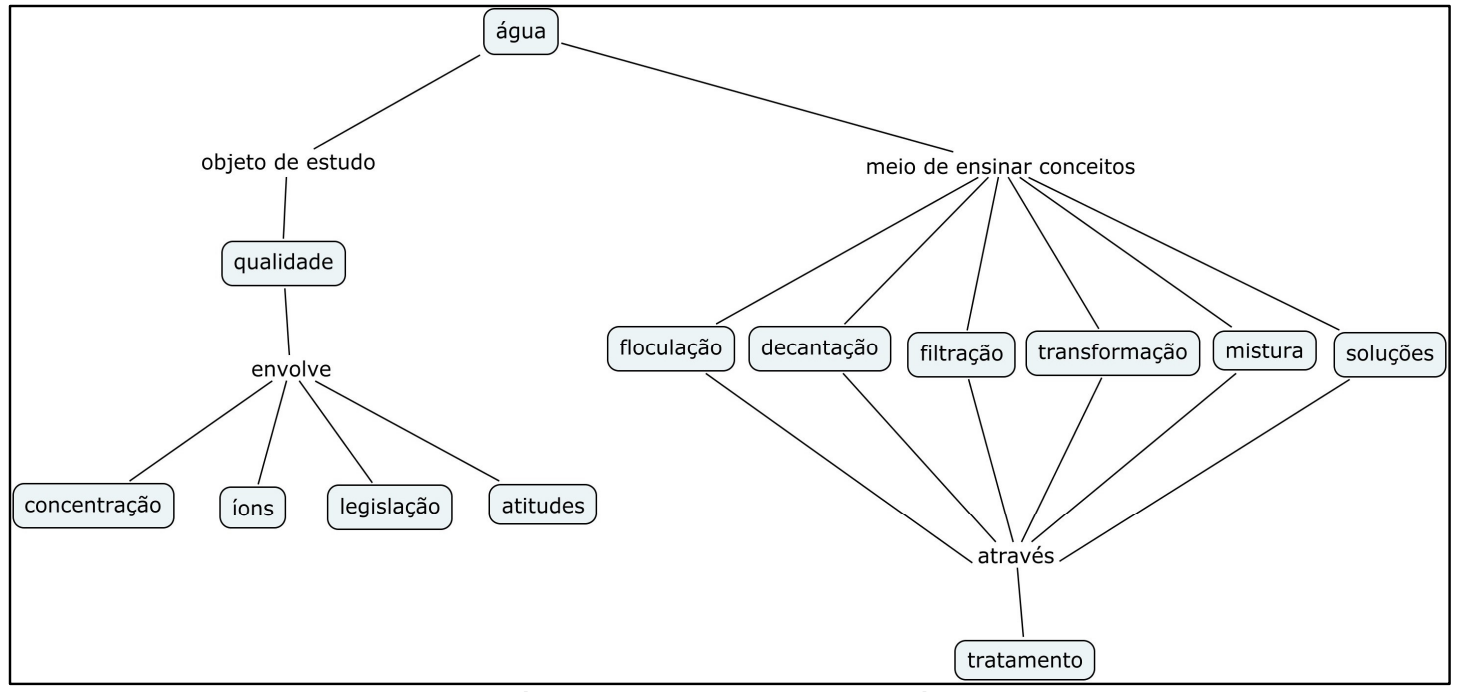

Figura 29. Mapa conceitual das idéias do (P9) sobre os conteúdos tratados e como os aborda.

Como objeto de estudo, a água torna-se o foco central do estudo, quando P9 aborda em suas aulas a falta de qualidade nos rios, os conceitos íons e concentração, e também, a legislação através das leis e multas. Segue o relato:

P9: "(...) explico que a qualidade da água está acabando devido a poluição, trago fotos de sites de empresas que utilizam metais pesados em seus processos industrias e que algumas empresas não respeitam as leis ambientais, lançam metais nos rios em grande quantidade (...) explico então, que os elementos chumbo, cádmio, mercúrio e cianeto explico que são íons que doam e recebem elétrons, faço a distribuição na lousa realizamos exercícios, depois explico concentração comum, as toneladas que são lançadas de metais pesados nos rios, calculo na lousa e realizamos exercícios também (...) eu solicito um seminário em grupo sobre as leis ambientais que protegem a água e outros recursos naturais, leis e as multas, eu percebo que os alunos desconhecem as leis, eles acham que não existem, com isto o aluno pode entender um pouco mais sobre as leis e a fiscalização nas industrias, pois muitas vezes eles desconhecem as leis e as multas ambientais de proteção a água, com isso ele começa a perceber e a relacionar a poluição com os metais no seu cotidiano (...)”.

Também, aborda atitudes de proteção e conservação. Segue o relato:

P9: “(...) tento desenvolver no aluno atitudes de conservação e proteção, pois estes problemas ambientais fazem parte do seu cotidiano, ele deve denunciar estas empresas clandestinas a CETESB (...)".

A falta de qualidade é abordada como um tema gerador, ensina os conceitos, os processos tecnológicos industriais que lançam o esgoto sem tratamento nos rios, os impactos na sociedade como a escassez da potabilidade, o conhecimento sobre as legislações ambientais, trata atitudes de proteção em relação a crescente poluição. Os pesquisadores em QA, QAG, EA e EQ julgam importante a abordagem da qualidade e atitudes. 
O professor P9 aborda os conceitos: floculação, decantação, filtração, transformações químicas, misturas e soluções, através do tratamento da água. Os pesquisadores de $Q A$, EA e EQ julgam importante a abordagem do custo do tratamento para a sociedade. No entanto, estes aspectos não são explorados por P9, pois utiliza a água como um meio para ensinar apenas conceitos científicos, como pode perceber em seu relato:

P9: “(...) quando explico trago um vídeo que eu gravei em uma visita na Sabesp é completo e amplo têm todas as etapas, então ensino a floculação adicionamos o sulfato de alumínio e hidróxido de sódio que vai precipitar faço a reação na lousa, eu desenho na lousa a decantação explicando a fase homogênea e heterogênea, a filtração simples. As questões eles respondem para entregar: escreva a transformação química que ocorre na floculação. Pesquise outros exemplos de mistura homogênea e heterogênea (...)".

De acordo com os conceitos citados pelos pesquisadores em EQ figura 3, atribuem uma grande importância aos conceitos: propriedades, ligações química, reações e soluções. Como se pode verificar na figura 29, P9 não menciona tratar propriedades.

Em relação a visão ambientalista, apresenta um enfoque naturalista, pois trata os conceitos científicos relacionados à água. Apresenta uma visão social, pois discute o problema da escassez da qualidade, uma visão ecologista, pois discute política através das leis ambientais, e também uma visão conservadora.

O tratamento dado por P9 a água, pode-se comparar com a visão dos pesquisadores em QA, EA e QAG, conforme apresentado na trama de conteúdos da figura 30.

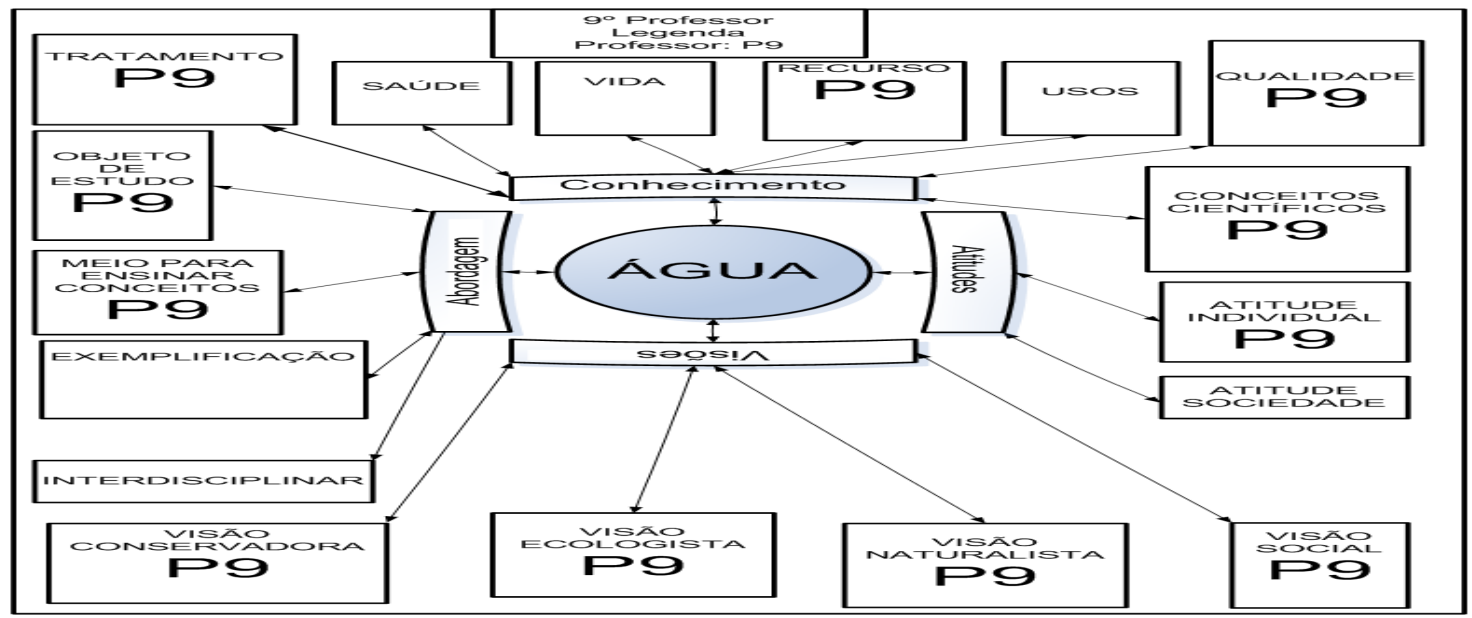

Figura 30. Trama de conteúdos (P9). 
A abordagem do P9 está relacionada à possibilidade discutida pelos pesquisadores em $E Q$, pois trata a qualidade e o recurso de maneira contextualizada, como um objeto de estudo, porém, quando aborda o tratamento 0 professor está preso a uma forte subordinação de organização conceitual. Com relação à visão dos pesquisadores em $\mathrm{EQ}$, a figura 31 , demonstra a realidade $\mathrm{e}$ subordinação do P9.

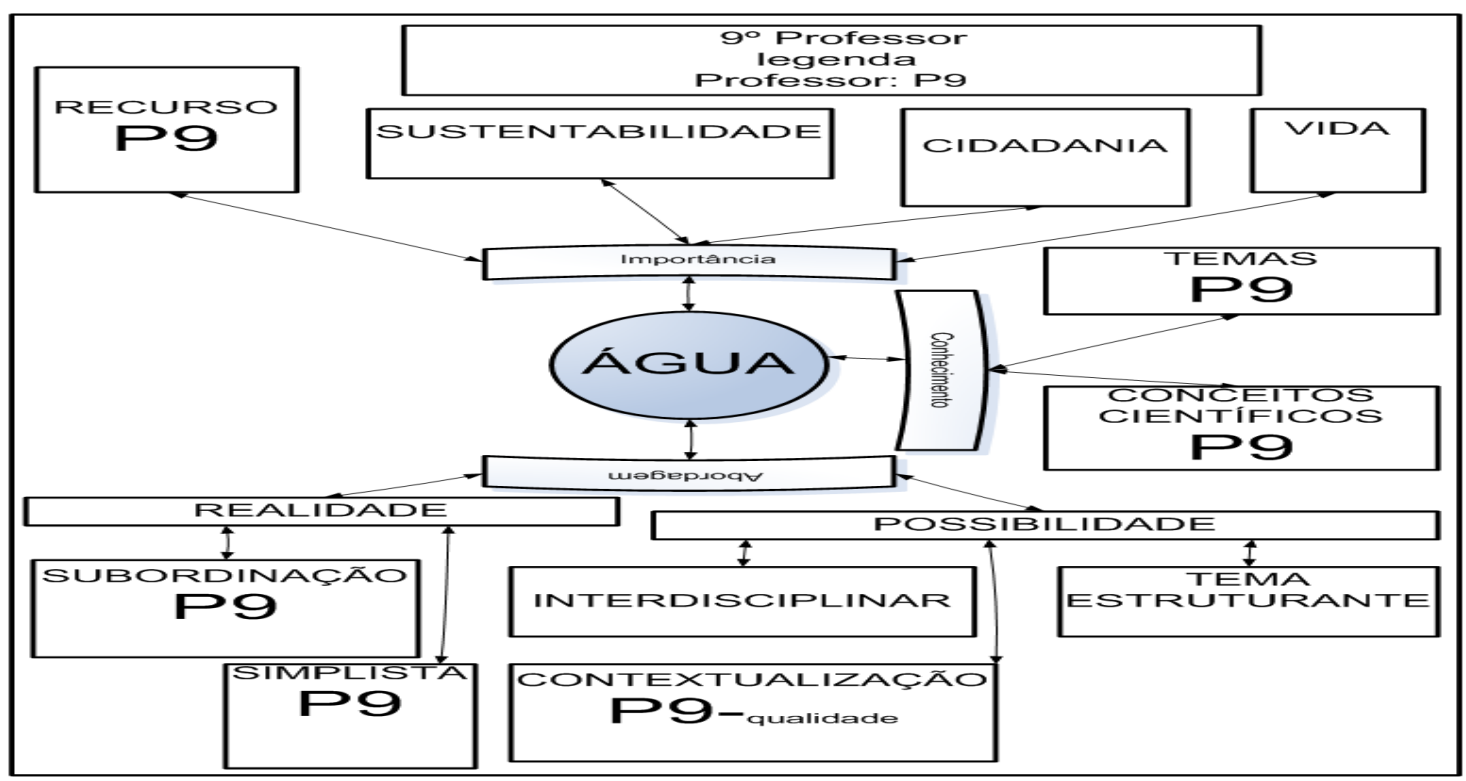

Figura 31. Trama de conteúdo (P9).

Considerando os temas apontados como importantes no ensino pelos pesquisadores em EQ figura 4, podemos verificar que o uso e o ciclo não são mencionados por P9 figura 29. Este professor não aborda as propriedades pertinentes ao ciclo da água como os conceitos de matéria, substância, átomo, ponto de ebulição, fusão e as variações de pressão. Propiciando assim, em seus alunos, uma imensa dificuldade de entendimento e aprendizagem sobre a natureza da água.

O P10 trata os temas: ciclo, condutibilidade e tratamento, e também alguns, conceitos científicos. A relação entre os conteúdos tratados e a abordagem dada está evidenciada no mapa conceitual figura 32 , elaborado pela pesquisadora. 


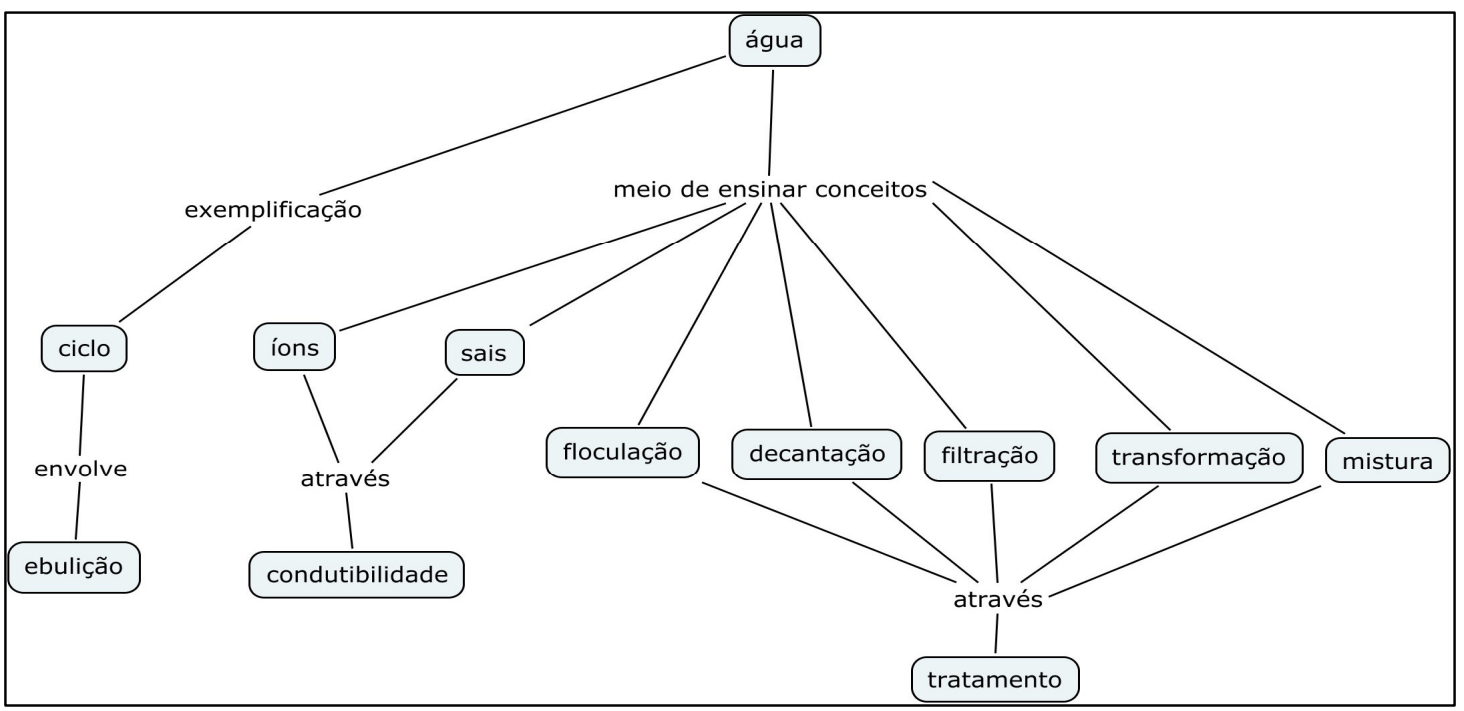

Figura 32. Mapa conceitual das idéias do (P10) sobre os conteúdos tratados e como os aborda.

O P10 aborda de maneira exemplificada o ciclo hidrológico, apenas comenta a ebulição da água. Segue o relato:

P10: “(...) eu só falo que a transpiração é a água passando do liquido para o gasoso ponto de ebulição, não cobro nada para nota, não cobro exercícios, só comento este capítulo do livro o ciclo da água com este gancho da transpiração, não discuto os gráficos e os outros estados físicos da água (...)".

Os pesquisadores em EA, QAG e EQ consideram importante tratar o ciclo não como exemplificação, mas como o próprio objeto de estudo.

O professor P10 aborda os conceitos íons e sais, através da condutibilidade elétrica da água. Segue o relato:

P10 “(...) explico condutibilidade elétrica, o conceito de íons e sais na lousa do laboratório, explico que uma água destilada é isenta de íons, então realizo um experimento no laboratório com o aparelho de condutibilidade elétrica eles observam que a destilada não conduz corrente, pois é isenta de sais e a do mar que tem uma grande quantidade de sais conduz corrente, e a água potável conduz também. Assim eles entendem os sais e os íons, e que os sais conduzem eletricidade através o experimento(...) a aula prática ajuda o aluno entender(...)explico o conceito de sais e os íons na lousa do laboratório, explico que uma água destilada é isenta de íons(...) cobro uma atividade para entregar, para verificar o que eles aprenderam, com questões: explique por que a lâmpada da água destilada não ascendeu? Explique por que a lâmpada da água do mar ascendeu rápido? A água potável tem íons? Quais?(...)".

Os pesquisadores não apontam a abordagem da condutibilidade elétrica no ensino de química. Também aborda os conceitos floculação, decantação, filtração, transformações químicas, misturas e filtração simples, através do tratamento da 
água. Segue o relato:

Também aborda os conceitos floculação, decantação, filtração, transformações químicas, misturas e filtração simples, através do tratamento da água. Segue o relato:

P10: “(...) eu explico transformações, misturas através do tratamento da água da SABESP, eu considero muito importante têm que entender a química que ocorre no tratamento (...) eu desenho colorido em uma cartolina a represa e todas as etapas e em outra os conceitos que estão envolvidos, faço a transformação química que ocorre na floculação com o sulfato de alumínio, explico que ocorre a decantação, pois existem mistura homogênea que se solubilizam e heterogênea que não se solubilizam e por isso ocorre uma separação, levo as cartolinas em todas as salas (...) depois eu peço para responderem questões como: explique a etapa da floculação? Explique por que utilizamos o sulfato de alumínio. Cite outras mistura heterogêneas que você conhece (...)".

Trata a condutibilidade elétrica e o tratamento com o objetivo conceitual, sua prioridade é que o aluno entenda os conceitos químicos.

Os pesquisadores em QA, EA e EQ também julgam importante a abordagem do tratamento e o custo para a sociedade, e também, os pesquisadores em QA, EA, QAG e EQ julgam importante o tratamento de atitudes de valorização.

Apresenta uma visão naturalista, pois em vários descreve a água através de conceitos científicos. De acordo com os conceitos citados pelos pesquisadores em (EQ), (figura 3) atribuem uma grande importância a propriedades, ligações química, reações e soluções. Como se pode verificar na figura 32, P10 menciona tratar todos os conceitos.

O tratamento dado por P10 a água, pode-se comparar com a visão dos pesquisadores em QA, EA e QAG, conforme apresentado na trama de conteúdos da figura 33. 


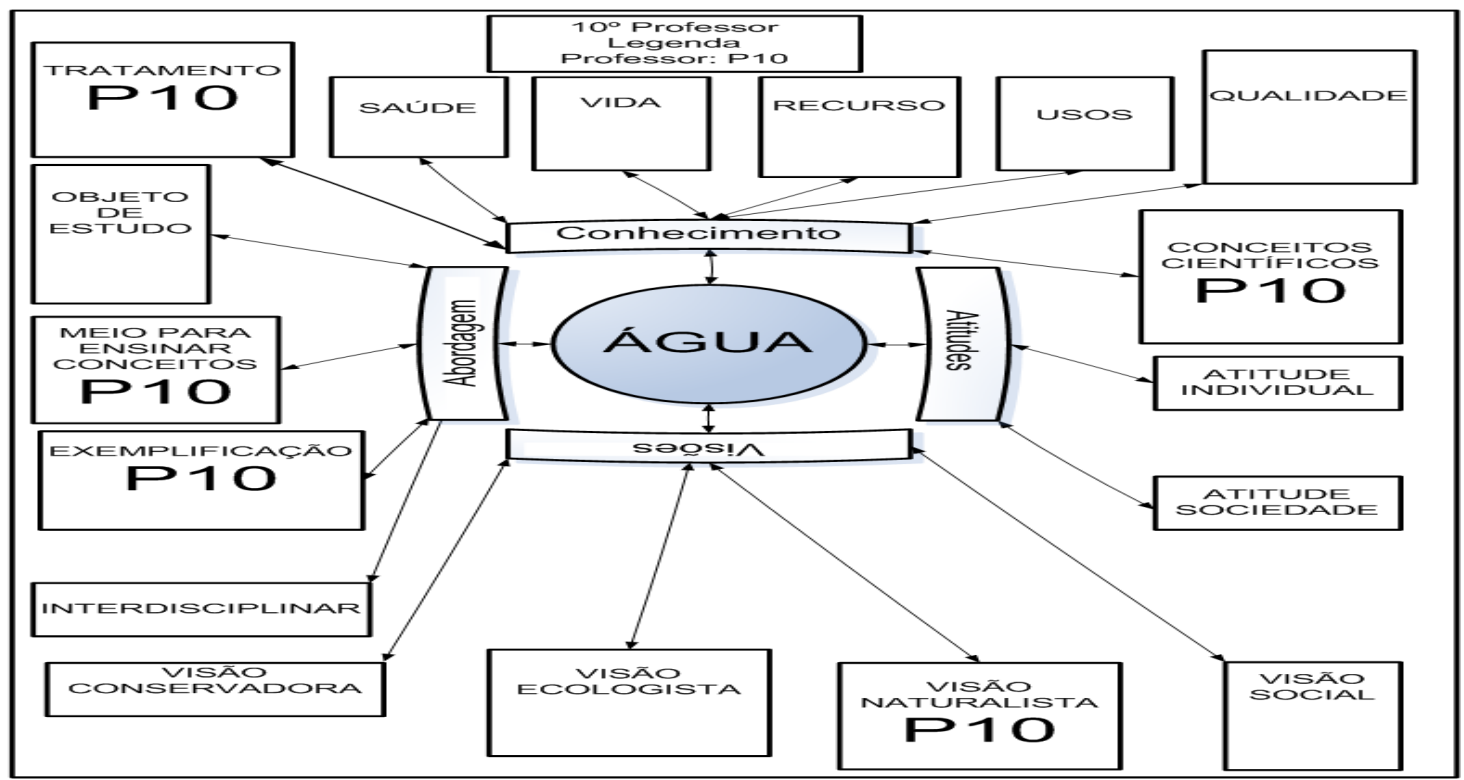

Figura 33. Trama de conteúdos (P10)

A abordagem do P10 está relacionada à categoria realidade, discutida pelos pesquisadores em $E Q$, pois parece haver uma subordinação do professor a uma organização de conteúdos que não contempla a temática água como um tema estruturante, reduzindo, praticamente, a exemplificações e apresentações de conceitos, numa visão bastante reducionista.

Com relação à visão dos pesquisadores em $\mathrm{EQ}$, a figura 34 , demonstra a realidade e subordinação do $\mathrm{P} 10$.

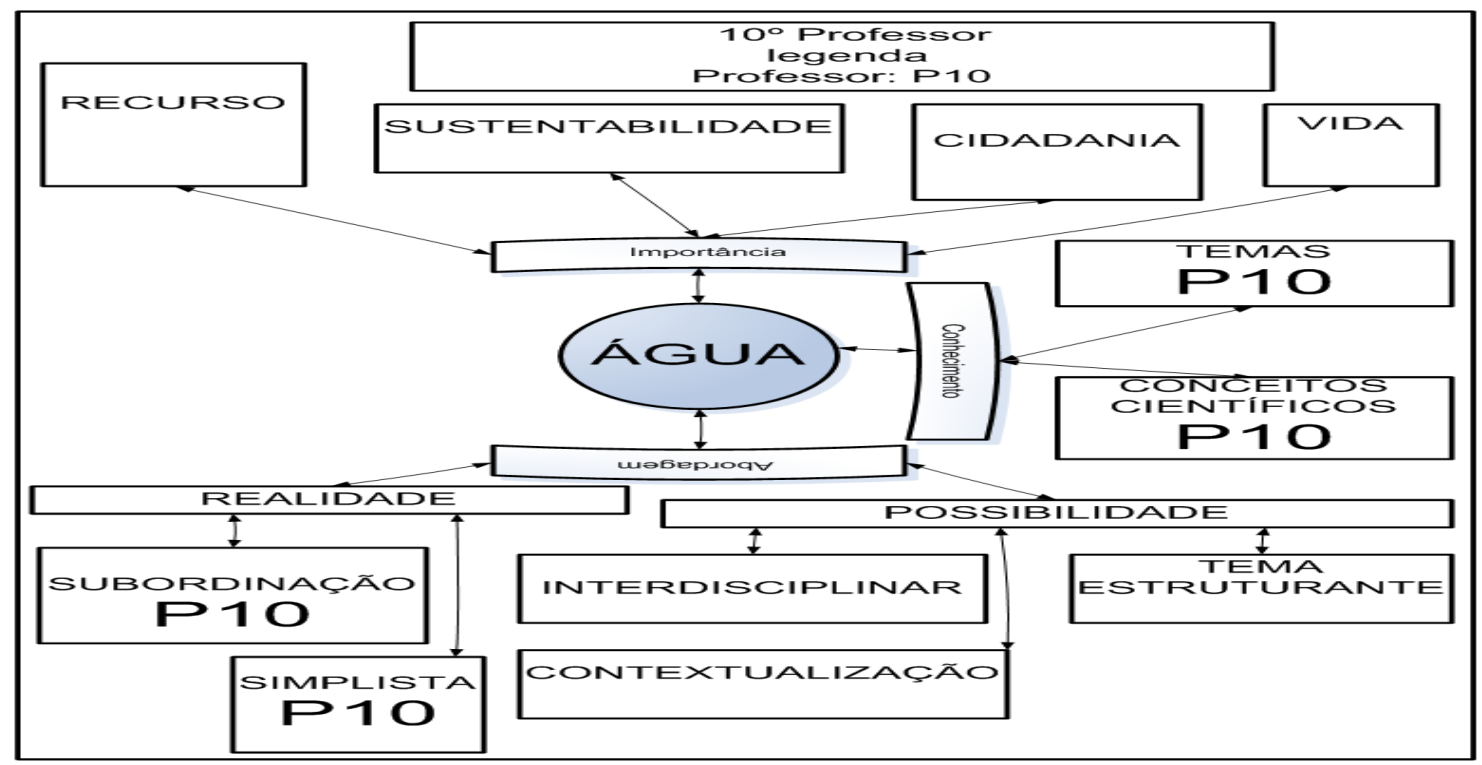

Figura 34. Trama de conteúdos. 
Considerando os temas apontados como importantes no ensino pelos pesquisadores em EQ figura 4, podemos verificar que o uso não é mencionado por P10(vide figura 32), o tratamento da água mesmo que tenha sido mencionado, é apenas um caminho para a abordagem de conceitos científicos. O professor não apresenta uma preocupação em abordar questões relativas a atitudes pró ambientais, a importância da água potável para a vida, restringindo em seus alunos o desenvolvimento de uma visão crítica, e responsável, em relação à escassez da água potável.

Apresentamos na figura 35, uma única trama conteúdos, com os temas e metodologias utilizados pelos 10 professores que participaram desta pesquisa. $O$ tratamento dado pelos 10 professores à água pode ser comparado com a visão dos pesquisadores em QA, EA e QAG, conforme apresentado na trama de conteúdos da figura 1. 


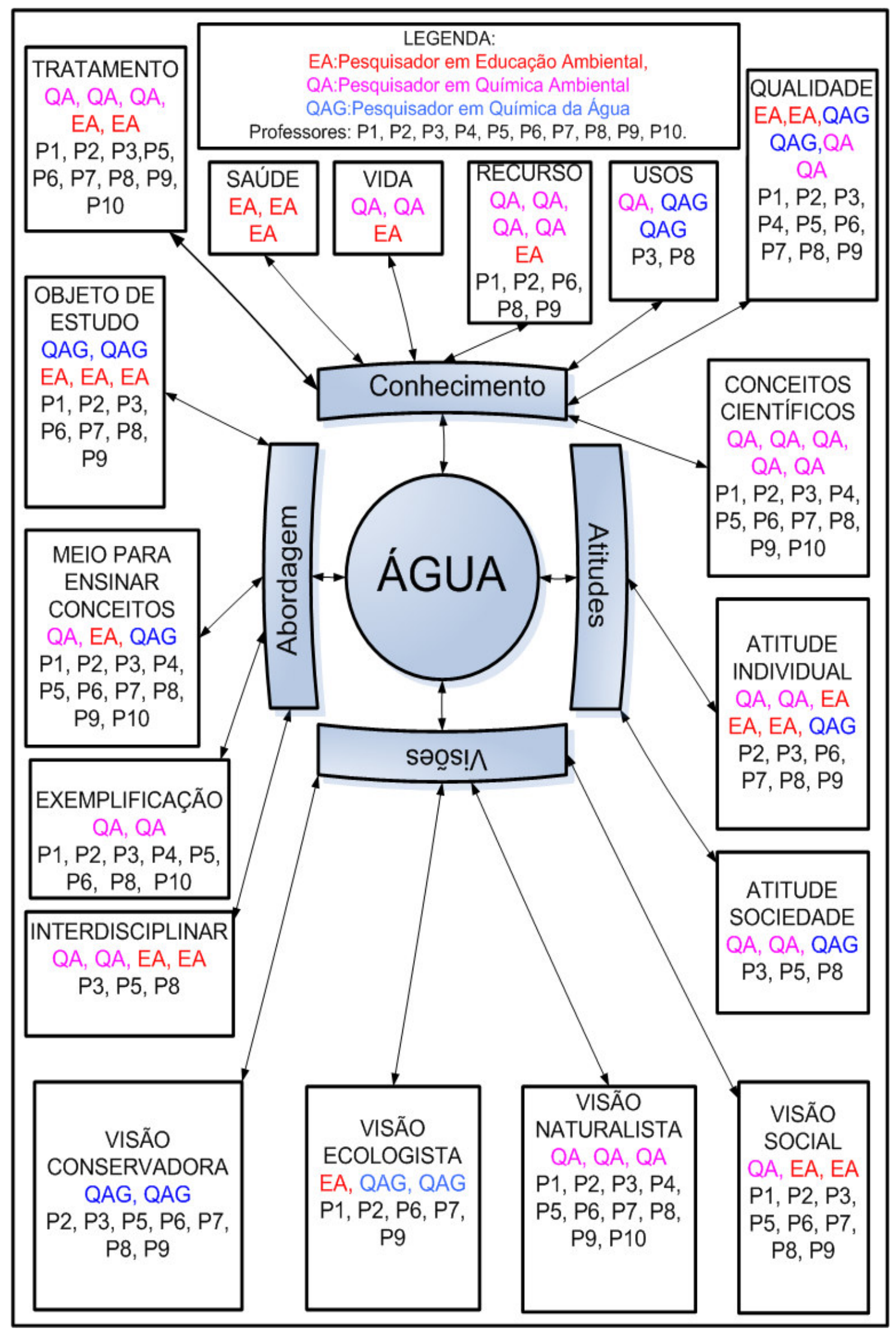

Figura 35. Trama de conteúdos dos professores e pesquisadores em QA, QAG e EA. 
Pode- se comparar também com a visão dos pesquisadores em EQ figura 2, e a do conjunto dos professores, como é mostrado na figura 36 .

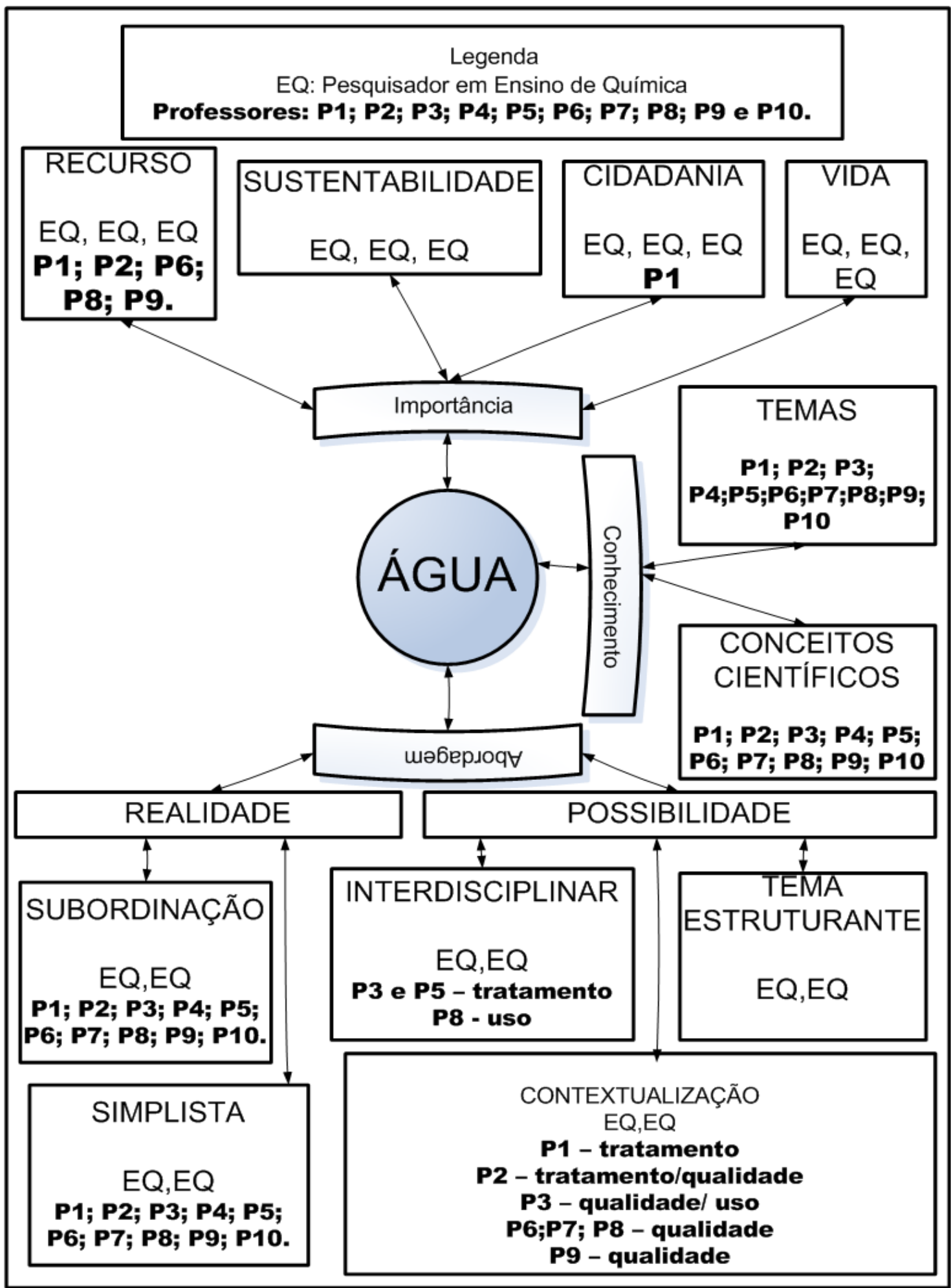

Figura 36. Trama de conteúdos dos professores e pesquisadores em EQ. 
Embora todos os professores participantes nesta pesquisa tratem de conceitos relativos à água, abordam questões referentes como: responsabilidade e reflexão em relação ao uso indevido, a escassez da potabilidade, a conservação, o zelo e o respeito pelo tratamento.

Apenas três dos dez, planejam atividades com foco no desenvolvimento de atitudes coletivas, por meio de projetos interdisciplinares, em parceria com a comunidade. Auler (2002) aponta que os temas sociais são importantes no ensino, pois possibilitam relações entre os aspectos científicos, sociais e tecnológicos, promovendo condições para o desenvolvimento de atitudes de tomada de decisão por parte dos alunos.

Chama a atenção que pesquisadores e professores convergem no que diz respeito à ênfase em atitudes individuais, o que pode refletir, por um lado, uma visão conservadora do papel da escola, centrada na transmissão - aquisição de conteúdos. Também, pode se refletir o não desprendimento de uma dada realidade, que valoriza o individual em detrimento do coletivo

Em concordância com os pesquisadores, as etapas do tratamento e a degradação compulsória da qualidade da água são abordadas pela maioria dos professores. Tendo em vista a inserção de vários conceitos químicos e aspectos tecnológicos, e que o aluno reflita sobre quais são suas atitudes e da sociedade que têm levado a uma deteriorização gradativa da qualidade deste recurso natural. Sachs (2004) relata que a degradação ambiental é o resultado de dois processos: a exploração desenfreada dos recursos naturais por parte das minorias ricas, e a utilização dos recursos naturais pelos pequenos agricultores, obrigados a lançar mão de estratégias de sobrevivência que passam pelo esgotamento dos solos e a contaminação das águas.

Como somente a metade dos professores entrevistados abordam assuntos relativos à água como um recurso, e apenas dois a usos, pode argumentar que o ensino de Química está perdendo uma excelente oportunidade de contribuir para que $o$ aluno se informe, debata e construa sua própria avaliação sobre a disponibilidade, distribuição e uso da água no planeta, sobre aspectos econômicos, tecnológicos e políticos relativos a exploração desse recurso. Como aponta Pelicioni (1998) um dos objetivos do PRONEA- Programa Nacional de Educação 
Ambiental é conscientizar a sociedade para que utilizem os recursos naturais de forma responsável. Pode-se discordar da idéia do professor conscientizador, mas defendemos o ponto de vista de que o ensino pode ser provido de informações, conhecimentos, leituras e debates de situação que favoreçam o aluno a tomar suas decisões e atitudes.

Ainda, deve-se considerar que nenhum professor mencionou tratar de aspectos relacionados à vida e saúde, temas considerados importantes pelos especialistas. Pode-se conjecturar que tais assuntos poderiam ser abordados pelos professores de Química, como sendo do domínio da disciplina de Biologia. Sem tirar o mérito desta última disciplina para tratar de aspectos muito importantes sobre vida e saúde relativos à água, consideramos que os professores de Química também têm uma contribuição a dar, tratando, por exemplo, de aspectos relativos a importância dos sais minerais presentes na água para o metabolismo do ser humano e dos animais.

A abordagem de aspectos relativos à qualidade, tratamento, uso, ciclo e recurso, está vinculado ao tratamento de vários conceitos como: transformações químicas, funções inorgânicas, propriedades, ligações, condutibilidade elétrica e soluções. Como citado anteriormente, o tema água propicia a inclusão de vários conceitos, constatamos em várias propostas de ensino como (KRUGER, 2007; QUADROS, 2004; SILVA, 2003; GEPEQ, 2005).

Os conceitos de $\mathrm{pH}$ e equilíbrio químico são apontados apenas por um professor. A Proposta Curricular de Química do Estado de São Paulo ( 2008), trata estes conceitos como sendo fundamentais no Ensino Médio, pois permite que o aluno entenda a caracterização da água potável para o consumo humano, a importância do pH no sistema produtivo e no metabolismo do ser humano, e compreenda nos níveis quantitativos e qualitativos que a adição de solutos pode modificar o $\mathrm{pH}$ da água.

Os temas abordados pela maioria dos professores são: qualidade, tratamento, contaminação, ciclo, recurso e legislação. Nenhum professor trata os temas: formação de nuvens, fotossíntese, vida e clima, que de acordo com a figura 4, foram citados como importantes pelos pesquisadores em EQ. Os temas foram 
propostos pelos pesquisadores em EQ. Nenhum professor apontou que tratava conceitos relativos à água, na terceira série do Ensino Médio.

A tabela 6 mostra os temas abordados e as respectivas séries que são tratados. 
Tabela 6. Temas citados pelos professores e as respectivas séries que são abordados.

\begin{tabular}{|c|c|c|c|c|c|c|c|c|c|c|c|c|c|c|c|c|c|c|c|c|}
\hline Séries & $1^{\mathrm{a}}$ & & & & & & & & & & $2^{\mathrm{a}}$ & & & & & & & & & \\
\hline Professores & 1 & 2 & 3 & 4 & 5 & 6 & 7 & 8 & 9 & 10 & 1 & 2 & 3 & 4 & 5 & 6 & 7 & 8 & 9 & 10 \\
\hline \multicolumn{21}{|l|}{ Conteúdos } \\
\hline Recurso & $\mathbf{x}$ & $\mathbf{x}$ & & & & & & & & & & & & & & & & & & \\
\hline $\begin{array}{l}\text { Qualidade da } \\
\text { água }\end{array}$ & & & & & $\mathbf{x}$ & $\mathbf{x}$ & & $\mathbf{x}$ & $\mathbf{x}$ & & $x$ & $\mathbf{x}$ & $\mathbf{x}$ & $\mathbf{x}$ & & & $\mathbf{x}$ & & & \\
\hline Contaminação & & & & & $\mathbf{x}$ & $\mathbf{x}$ & & $\mathrm{x}$ & $\mathbf{x}$ & & $x$ & $x$ & $x$ & $\mathbf{x}$ & & & $x$ & & & \\
\hline $\begin{array}{l}\text { Tratamento da } \\
\text { água potável }\end{array}$ & $\mathbf{x}$ & & & & $\mathbf{x}$ & & $\mathbf{x}$ & $\mathbf{x}$ & & & & $x$ & $\mathbf{x}$ & & & $x$ & & & $x$ & $\mathbf{x}$ \\
\hline Distribuição & & & & & & $\mathbf{x}$ & & $\mathbf{x}$ & & & & & & & & & & & $x$ & \\
\hline Política & $x$ & & & & & $\mathbf{x}$ & & & $\mathbf{x}$ & & & $x$ & & & & & $x$ & & & \\
\hline Ciclo da água & $x$ & $x$ & $x$ & $\mathrm{x}$ & & $x$ & & $\mathrm{x}$ & & $x$ & & & & & & & & & & \\
\hline \multicolumn{21}{|l|}{ Saúde } \\
\hline Usos & & & & & & & & & & & & & $\mathbf{x}$ & & & & & $x$ & & \\
\hline \multicolumn{21}{|l|}{ Clima } \\
\hline \multicolumn{21}{|l|}{ Vida } \\
\hline \multicolumn{21}{|l|}{ Fotossíntese } \\
\hline $\begin{array}{l}\text { Formação de } \\
\text { nuvens }\end{array}$ & & & & & & & & & & & & & & & & & & & & \\
\hline
\end{tabular}


Como se pode perceber pela tabela 6, os temas são abordados apenas em uma série, não havendo recursividade, ou seja, aprofundamento ou ampliação em outras séries. Mesmo considerando a possibilidade de uma abordagem temática, o que não é o caso para os professores entrevistados, que de certa maneira, poderia limitar o tema a uma dada série, a recursividade é um aspecto importante a ser considerado na organização curricular, pois permite a retomada de conhecimentos prévios, tendo em vista tanto sua reorganização e ampliação, considerando outros conhecimentos aprendidos, como sua utilização como suporte à aprendizagem de novos conceitos.

Construímos a tabela 7, com as séries citadas, e a soma de professores que citaram cada tema.

Tabela 7. Número de professores e temas citados por série.

\begin{tabular}{|c|c|c|}
\hline Conteúdos & Séries & $\begin{array}{l}\text { Número de } \\
\text { professores }\end{array}$ \\
\hline Recurso & $1^{a}$ & 2 \\
\hline Qualidade da água & $\begin{array}{l}1^{a} \\
2^{a}\end{array}$ & $\begin{array}{l}4 \\
5\end{array}$ \\
\hline Contaminação & $\begin{array}{l}1^{a} \\
2^{a}\end{array}$ & $\begin{array}{l}4 \\
5\end{array}$ \\
\hline $\begin{array}{l}\text { Tratamento da água } \\
\text { potável }\end{array}$ & $\begin{array}{l}1^{a} \\
2^{a}\end{array}$ & $\begin{array}{l}4 \\
5\end{array}$ \\
\hline Distribuição & $\begin{array}{l}1^{\mathrm{a}} \\
2^{\mathrm{a}}\end{array}$ & $\begin{array}{l}2 \\
1\end{array}$ \\
\hline Política & $\begin{array}{l}1^{a} \\
2^{a}\end{array}$ & $\begin{array}{l}3 \\
2\end{array}$ \\
\hline Ciclo da água & $1^{a}$ & 7 \\
\hline Saúde & - & - \\
\hline Usos & $2^{a}$ & 2 \\
\hline Clima & - & - \\
\hline Vida & - & - \\
\hline Fotossíntese & - & - \\
\hline Formação de nuvens & - & - \\
\hline
\end{tabular}

Os temas que a maioria dos professores aborda, nas $1^{\underline{a}}$ e $2^{2}$ série do ensino médio, são: ciclo da água, qualidade, contaminação e as etapas do tratamento, às vezes, como objeto de estudo ou descrições e exemplificações de conceitos. A legislação é citada por cinco professores, quando abordam a qualidade da água.

Com relação às visões sobre ambiente, todos os professores apresentam uma visão naturalista, ou seja, quando tratam temas relacionados à água, 
apresentam uma explicação ou exemplificação, baseada em conceitos químicos e físicos (LAGO e PÀDUA, 1989).

A maioria dos professores apresenta uma visão social e conservacionista, pois trata a falta de qualidade, o uso indevido, o custo do tratamento e a importância do recurso água para a sociedade, através de discussões, dando ênfase a atitudes de responsabilidade, zelo, conservação e respeito à água (MELLO e TRIVELLATO 1999)

Ainda, cinco professores apresentam uma visão ecologista, quando abordam a qualidade e o tratamento da água em suas aulas ou através de projetos com a comunidade, ou seja, existe uma preocupação em explicar a legislação que garante a potabilidade e que todo cidadão têm direito a saneamento ambiental.

De maneira geral, os professores abordam o tema mais como um meio para ensinar conceitos do que como um objeto de estudo, embora todos reconheçam a importância do ensino da água. Chassot (2001) relata que o ensino que possibilita o estudo do cotidiano, traz muitas vezes o objetivo apenas de ensinar os conceitos científicos, ocorrendo um reducionismo nessa perspectiva de contextualização.

Todos os professores abordam a qualidade, o tratamento, o uso, o recurso e o ciclo, em momentos diferentes em suas aulas, como meio para ensinar conceitos, ou seja, suas metodologias estão fortemente ligadas a um ensino tradicional. Isto ocorre, pois, muitas vezes o professor se torna dependente do livro didático, que segundo a pesquisadora Watabe (2008) que analisou várias coleções de livros de química, aponta que há certamente muita descrição sobre a questão do pH, soluções ácidas e básicas, hidrólise, eletrólise, misturas, concentrações e íons que são consideradas de forma não contextualizada, aparecem algumas caixas ao longo dos capítulos, citando chuva ácida ou poluição das águas.

Alguns professores tratam a água como um objeto de estudo, ou seja, um tema gerador, abordando conceitos científicos, atitudes de responsabilidade, zelo e respeito em relação à qualidade da água, política e economia. Freire (1987) aponta que o ensino através de temas geradores possibilita aos homens uma maneira crítica de pensarem sobre o seu cotidiano e o mundo em que vivem.

Verificamos que a maioria dos professores em alguns momentos, trata 0 ensino do tema água através de exemplos, não existindo preocupação em propiciar 
ao aluno uma reflexão sobre a problemática da água. Na maioria das vezes o ciclo da água foi abordado pelos professores de química de maneira superficial e exemplificado, através de exemplos retirados dos livros didáticos. De acordo com a pesquisa de Watanabe (2008), os estudantes de Pedagogia e os alunos do ensino fundamental, também representam uma visão superficial e estática do ciclo da água, ou seja, é um ciclo onde a mesma quantidade de água evapora num determinado intervalo de tempo.

Nenhum professor aborda sustentabilidade e vida, apenas um trata a questão que todo cidadão têm direito a saneamento ambiental. Três abordam que a água é um recurso natural rico em matérias primas, fundamental a sociedade.

A abordagem simplista e subordinada dos professores, muitas vezes está relacionada, a sua formação acadêmica. Menezes e Farias (2003) em sua pesquisa com alunos da graduação em Química, verificaram que eles apresentam dificuldades em entender os conceitos científicos e os aspectos sociais envolvidos na temática da água, pois, são divididos por disciplinas curriculares ao longo do curso, e muitas vezes, são tratados de maneira superficial e descritiva.

O tema qualidade é tratado por quatro professores com ênfase nos conceitos científicos, na legislação que garante água com qualidade a todos, e atitudes de irresponsabilidade que têm contribuído com a escassez da potabilidade. Kruger e Lopes (1997) apontam que os temas geradores estão presentes no cotidiano das pessoas, sendo importante que os alunos sejam estimulados a perceber as relações e implicações desses temas com suas vidas. A água, como tema gerador, proporciona questionamentos sobre aspectos da realidade deste recurso natural, criando uma abertura para que o aluno possa conhecer compreender e intervir nesta problemática propiciando a ele aluno, uma alfabetização científica (ACEVEDO, 2003).

\section{Capítulo 6. Conclusão e Considerações finais}

A contribuição dos especialistas puderam nos revelar os conhecimentos importantes sobre a água que as pessoas deveriam ter, de maneira a contribuir com o exercício de sua cidadania. Assim, nossos alunos, ao terminarem o ensino médio deveriam saber sobre a disponibilidade de água no planeta, seu papel na 
manutenção da vida e da saúde, os usos que a sociedade faz os padrões de qualidade e o tratamento que a água recebe ou deveria receber, seu custo, suas etapas e seus benefícios. No ensino desses conhecimentos, deveria ser discutida e enfatizada a responsabilidade que individualmente cada um tem, de zelar pela qualidade da água e pelo seu uso controlado. Ainda os especialistas foram unânimes em afirmar que certos conceitos químicos são relevantes para o entendimento da temática da água.

Quanto às atitudes coletivas são apontadas pelos pesquisadores, porém com menos ênfase, sendo citado, por exemplo, que projetos deveriam ser realizados na escola em parceria com a comunidade, visando à construção de atitudes de responsabilidade e respeito.

Assim, pode-se conjecturar que esses pesquisadores percebem certo limite na ação do professor em sala de aula, ou ainda consideram temas ambientais relevantes na educação científica no sentido que os alunos entendam as "questões ambientais no contexto de suas vidas" e "suas vidas no contexto das questões ambientais" (Dillon, 2002). Poder-se-ia contrapor a esta, uma visão de ensino que incorpora o caráter político da problemática sócio-ambiental, e a democratização das decisões envolvendo a ciência e a tecnologia (Auler e Delizoicov, 2006), que parece não fazer parte das concepções da maioria dos pesquisadores.

Com relação à abordagem, os pesquisadores em QA, EA e QAG chama atenção a pluralidade dos enfoques sugeridos, sem que haja predomínio de um deles, o que pode indicar a relevância do tema para os pesquisadores, devendo ser abordado desde uma simples exemplificação de conceitos químicos, até como um objeto de estudo. Já, os especialistas em EQ defendem enfoques temáticos e interdisciplinares, que segundo eles, contribuiriam para a formação cidadã a respeito da problemática da água.

Os professores de Química participantes desta pesquisa atribuem importância ao tema, sendo que nenhum revelou um enfoque apenas no conteúdo, mas se pode perceber:

- ausência de abordagem mais problematizadora, mais contextuada socialmente; 
- ênfase em uma abordagem centrada no desenvolvimento de conceitos, tendo a temática da água mais como um pretexto, do que um objeto de estudo;

- pouca valorização de aspectos atitudinais, sejam esses individuais ou coletivos.

Os professores, de maneira geral, estão presos a uma seqüência de organização de conteúdos tradicionais, que os pesquisadores identificam como relação de subordinação, ao ensino tradicionalmente realizado em nossas escolas.

Assim, consideramos que a temática água ainda não é explorada nas escolas, contribuindo pouco para que o aluno entenda de maneira mais ampla e profunda tal temática e tenha conhecimentos que lhe permita refletir sobre suas próprias atitudes e tomar decisões sobre mudá-los ou não.

Como bem apontam os PCN+ (Brasil, 2002, p. 98):

A Química pode ser um instrumento da formação humana que amplia os horizontes culturais e a autonomia no exercício da cidadania, se o conhecimento químico for promovido como um dos meios de interpretar o mundo e intervir na realidade, se for apresentado como ciência, com seus conceitos, métodos e linguagens próprios, e como construção histórica, relacionada ao desenvolvimento tecnológico e aos muitos aspectos da vida em sociedade.

Os professores, de maneira geral, também apresentam uma multiplicidade de visões de acordo com os aspectos da temática abordada. A visão ecologista, entretanto, é a menos compartilhada entre os professores, que pouco tratam de situações políticas e econômicas relacionadas a água.

Não se trata de culpar os professores ignorando as condições de trabalho a que está submetido, hoje nas nossas escolas públicas. A alta carga horária, os baixos salários, os parcos recursos de que dispõem a escola e às vezes as deficiências na formação inicial, impedem o professor a uma rotina pedagógica em que há pouco, ou nenhum, lugar para a pesquisa, o planejamento e a reflexão sobre a ação.

A água deveria ser tratada como um objeto de estudo desde a formação inicial do professor, na graduação em Química, preparando o docente para abordar em suas aulas os problemas ambientais, permeando conceitos, tecnologias e atitudes individuais e coletivas. 
Consideramos, também, importante que a temática como objeto de estudo seja tratada em atividades de formação continuada de professores. Deve-se considerar que existem propostas e projetos co esses enfoques (Gepeq, 2005; São Paulo, 2007; Kruger e Lopes, 1997; São Paulo, 2008) que podem contribuir para que o professor entenda melhor a temática da água tratada como foco de ensino.

O resultado desta pesquisa poderá contribuir para ajudar aqueles professores que estão à procura de outras abordagens, e assim, possam criar seu próprio caminho no desenvolvimento deste tema, no ensino da Química. 


\section{Bibliografia}

ACEVEDO, J. A. Educación tecnológica desde uma perspective CTS. Uma breve revisión Del tema. Alambique, v.13, 1996.

Disponível em: < http://www.campus-oei.org/salactsi/acevedo5.htm>. Acessado em: 05/07/2008.

ACEVEDO, J.A., VÁZQUEZ, A.; MANASSERO, M.A. Papel de la educación CTS en una alfabetización científica y tecnológica para todas las personas. En línea en Revista Electrónica de Enseñanza de las Ciencias, v.2, n.2, p.2-32, 2003.Disponível: http://www.saum.uvigo.es/reec/. Acessado: 08/07/2008.

AGUIAR, C. A. C.; LIMA, A.V.; EPOGLOU, A. Higienização e potabilidade da água: uma parceria entre professore, escolas e universidade. In: Encontro Nacional de Ensino de Química XIV ENEQ. Anais. Universidade Estadual do Paraná. Paraná,2008.

Disponívelemhttp://www.quimica.ufpr.br/eduquim/eneq2008/trabalhos.htm. Acessado em: 01/05/09

AIKENHEAD, G.S.; RYAN,A.G. The development of a new instrument: views on Science- Tecnology-Society. Science Education, v.76, n.5, p. 15-26, 1992.

ANGOTTI, J. A. P.; AUTH, M. A. Ciência e tecnologia: implicações sociais e o papel da educação. Ciência \& Educação, v. 7, n. 1, p.15- 27, 2001.

AULER, D. Interações entre Ciência-Tecnologia-Sociedade no Contexto da Formação de Professores de Ciências. Tese de Doutorado. Florianópolis, 2002.

AULER, D.; BAZZO, W.A. Reflexões para a implementação do movimento CTS no contexto educacional brasileiro. Ciência \& Educação, v.7, n.1, p.1-13, 2001

AULER,D. DELIZOICOV,D.Ciência- Tecnologia- Sociedade: relações estabelecidas por professores de ciências. Revista Ensenanza de lãs Ciencias, v. 5, n. 2, p. 337-355, 2006.

BALLANTINE, R. R; PACKER, J. M. Teaching and learning in environmental education: developing environmental conceptions. The Journal of Environmental Education, v.27, n.2, p.25-32, 1996.

BARDIN, L. Análise de Conteúdo. Editora: edições, 1977.

BAR, V. Children's views about the water cycle. Science Education. v.73. n.4.p.481-500, 1989.

BOGDAN,R.; BIKLEN,S. Investigação qualitativa em educação: uma introdução á teoria e aos métodos. Coleção Ciências da Educação. Porto Editora, 1994. 
BRASIL. Secretaria de Educação Fundamental. Parâmetros curriculares nacionais: meio ambiente e saúde. Brasília: MEC/SEF. v.9, 1997.

BRASIL. Secretária de Educação Média e Tecnológica. Parâmetros curriculares nacionais: ensino médio. Ciências da natureza, matemática e suas tecnologias. Brasília: MEC. v.3, 1999.

BRASIL Secretaria de Educação Média e Tecnológica - Ministério da Educação e Cultura. PCN+ Ensino Médio: Orientações educacionais complementares aos Parâmetros Curriculares Nacionais. Brasília: MEC.SEMTEC, 2002.

CACHAPUZ, A. F. Epistemologia e Ensino de Ciências na Pós-Mudança Conceitual: Análise de um percurso de pesquisa. In: Encontro Nacional de Pesquisa em Ensino de Ciências. Anais em CD-ROM. Valinhos, 1999.

CAJAS, F. La alfabetización cientifica y tecnológica: La transposición didática Del conocimiento tecnológico. Ensenanza de las Ciencias, v. 19, n.2, 2-15, 2001.

CHASSOT, A. Alfabetização Cientifica: questões e desafios para a educação. Coleção Educação em Química. ljuí. Editora: ljuí, 2001.

COSTA, C.; ROCHA, G.; ARCÙCIÒ, M.; A entrevista. Dissertação de Mestrado Universidade de Lisboa, 2005.

Disponível: www.educ.fc.ul.pt/docentes Acessado em: 13/07/2008.

DELIZOICOV, D.; ANGOTTI, A. J.; PERNAMBUCO, M. M. Ensino de Ciências: fundamentos e métodos. São Paulo: Cortez, 2002.

DIAS,G.F. Educação Ambiental. Principios e Práticas. São Paulo. Editora:Gaia, 2000.

DILLON, J. Perspectives on environmental education related research in science education. International Journal of Science Education, v. 24, $\mathrm{n}^{\circ} 11, \mathrm{p}$. 1111-1117, 2002.

FONTES, A.; SILVA, I.R. Uma nova forma de aprender ciências: a educação em Ciência/ Tecnologia /Sociedade (CTS). Coleção Guias Práticos. Editora: Edições, 2004.

FREIRE, P. Professor sim, tia não: cartas a quem ousa ensinar.São Paulo. Editora: Olho d'água. 1993.

Ação cultural para a liberdade e outros escritos. Rio de Janeiro. Editora: Paz e Terra, 2002.

GARCìA, J.E. Hacía una teoria alternativa sobre los contenidos escolares. Espanha. Editora: Díada, 1998. 
GEPEQ (Grupo de Pesquisa em ensino de Química). Química e a Sobrevivência: Hidrosfera Fonte de Materiais. Livro do Professor. São Paulo: Editora: Edusp, 2005.

GLYNNHENRY. J.; HEINKE, G. W. Enviromental Science and Engineering. New Jersey. Prentice Hall, 1996.

GONDSENTEIN, S; SALVADOR, Z. Sustentabilidade da gestão da água e desenvolvimento sustentável. São Paulo. Editora: Senac, 2004.

GRASSI, M.T. As águas do Planeta Terra. Química Nova na Escola, $\mathrm{n}{ }^{\circ}$, maio, $\mathrm{p}$. 39-42, 2001.

KRUGER, V.; LOPES, M. V. C. Propostas para o ensino de química: águas. Editora: Porto Alegre, 1997.

LAGO, A; PADUA, J. A. O que é ecologia. São Paulo. Editora: Brasiliense, 1989.

LEFF, E. A complexidade ambiental. São Paulo. Editora: Cortez, 2001.

LUCATTO, G.L.; TALAMONI,B.L.J. A construção coletiva interdisciplinar em educação ambiental no ensino médio: a microbacia hidrográfica do ribeirão dos peixes como tema gerador. Ciência \& Educação,v. 13, n. 3, p. 389-398, 2007.

LUDKE, M.; ANDRÉ. M.E.A. Pesquisa em educação: abordagens qualitativas. Coleção Temas Básicos de Educação e Ensino. São Paulo. Editora: EPU, 1986.

LUFTI, M. Os Ferrados e Cromados: produção social e apropriação privada do conhecimento químico. ljuí. Editora: Unijuí, 1992.

MELLO, C; TRIVELATO, S. Concepções em educação ambiental. In: II Encontro Nacional de Pesquisa em Educação em Ciências. Anais em CD-ROM. Valinhos. Universidade Federal de Minas Gerais, 1999.

MENEZES,C.H.; FARIAs, G.A. Utilizando o monitoramento ambiental para o ensino de química pedagogia de projeto. Química Nova,v. 26, n.2, p.24- 35, 2003.

NOVAK, J. D. The Theory Underlying Concept Maps and How to Construct Them, 2003.

Disponível em: <http://cmap.coginst.uwf.edu/info/printer.html>. Acessado em: $21 / 10 / 2008$.

OSBORNE, J. R.; COSGROVE,M. M. Children's conceptions of the changes of state of water. Science Education Research,v. 20, n.9, p.825-838, 1983.

PELICIONI,A.F. Educação Ambiental na escola- um levantamento de percepções e práticas de estudantes de primeiro grau a respeito de meio 
ambiente e problemas ambientais. Dissertação mestrado. Universidade de São Paulo, São Paulo, 1998.

PINHEIRO, M. A. N; SILVEIRA, F. C. M. R; BAZZO, A. W. Ciência, Tecnologia e Sociedade: a relevância do enfoque CTS para o contexto do ensino médio. Ciência \& Educação, v. 13, n. 1, p. 71-84, 2007.

PIZZATO, C. M. Temas Ambientais na Química do Ensino Médio: visões de professores, licenciados e livros didáticos. Dissertação de mestrado. Universidade de São Paulo. São Paulo, 2002.

QUADROS, L. A. A água como tema gerador do conhecimento químico. Química Nova na Escola, №20, novembro, p.26-31, 2004.

RUDIO, F. V. Introdução ao projeto de pesquisa científica. Petrópolis. Editora: Vozes, 2002.

SACHS, I. O desenvolvimento sustentável: do conceito a ação: De Estocolmo a Johanesburgo. In: TAGNIN, R. DOWBOR, L. Administrando a água como se fosse importante: gestão ambiental e sustentabilidade. São Paulo. Editora: Senac. Capítulo 1, p. 7-14, 2005.

SALATI, E.; LEMOS, H. M. Água e o Desenvolvimento Sustentável. In: REBOUÇAS, A. C.; BRAGA, B. \& TUNDISI, J. G. (org). Águas Doces no Brasil Capital Ecológico, Uso e Conservação. São Paulo. Editora: Escrituras. Capítulo 2, p. 39-64, 1999.

SANTOS, J. M. O contexto ambiental nos livros didáticos de química: o ciclo da água como tema estruturador. Dissertação de mestrado. Centro Universitário Moura Lacerda. Ribeirão Preto, 2007.

SANTOS, W. L.; MORTIMER, E.F. A dimensão social do ensino de Química - Um estudo exploratório da visão de professores. II Encontro Nacional de pesquisa em Educação em Ciências. Atas em CD-Rom. Valinhos, 1999b.

SANTOS, W. L. P.; SCHNETZLER, R. P. Educação em Química: Compromisso com a Cidadania. Coleção Educação. ljuí. Editora: Unijuí, 1997.

SÃO PAULO. Oficinas Temáticas no Ensino Público: Formação Continuada de Professores. São Paulo. Secretaria da Educação do Estado de São Paulo, 2007.

SÃO PAULO. Proposta Curricular do Estado de São Paulo Ciências da natureza e suas tecnologias química: $2^{\mathrm{a}}$ e $3^{\mathrm{a}}$ séries do ensino médio caderno do professor . São Paulo. Secretaria da Educação do Estado de São Paulo, 2008.

SÃO PAULO. Proposta Curricular para o Ensino de Química. Secretaria da Educação. Coordenadoria de Estudos e Normas Pedagógicas. $-2^{\circ}$ grau. São Paulo, SE/CENP, 1988. 
SHIKLOMANOV, I. Recurso água. Monografia elaborada com os dados do programa hidrológico do Instituto de Petersburg, Rússia, 1998.

SILVA, E. L; MARCONDES, M. E. R. O professor de química e o ensino na perspectiva da ciência, tecnologia e sociedade. IV Congreso Iberoamericano de Educación Científica: innovación e socialización. Anaïs em CD-ROM. Perú, 2006.

SILVA, G. M. R. Contextualizando aprendizagens em química na formação escolar. Química Nova na Escola, n¹8, novembro, p. 26- 30, 2003.

SILVA, R. R.; MACHADO, L. F. P.; XIMENES, R. C. A.; SOUZA, B. K.; ARAÚJO, O. R. K. Concepções alternativas sobre a natureza da água. In: Encontro nacional de Ensino de Química XIV ENEQ. Anais. Universidade Estadual do Paraná. Paraná, 2008.

Disponívelem:http://www.quimica.ufpr.br/eduquim/eneq2008/trabalhos.htm. Acessado em: 01/05/09

TINÈ, Z. S. A educação ambiental no ensino a distância: um olhar sobre a proposta do SENAC. Educação Profissional: Ciência e Tecnologia, v.1, n.2, p.223230, 2007.

VASCONCELLOS, E.S.; SANTOS, W.L.P. Educação ambiental em aulas de química: refletindo sobre a prática a partir de concepções de alunos sobre meio ambiente e educação ambiental. In: Encontro Nacional de Pesquisa em Educação em Ciências VI ENPEC. Anais. Universidade de Florianópolis Florianópolis, 2007.

Disponível em: http://www.fae.ufmg.br/abrapec/viempec/. Acessado: 04/05/2009

WATANABE, G. Elementos para uma abordagem temática: a questão das águas e sua complexidade. Dissertação de mestrado. Universidade de São Paulo, 2008.

WATANABE, G.; KAWAMURA, M. R. Em busca de espaços curriculares para a questão da água. In: V Encontro Nacional de pesquisa em Educação em Ciências. Anais. Bauru, 2005. 


\section{Anexos}

Anexo 1. Questionário dos pesquisadores: Química Ambiental(QA), Química da Água(QAG), Educação Ambiental (EA).

Nome:

Telefone:

Endereço eletrônico:

Graduação:(Curso )instituição:

Pós- Graduação(Mestrado e Doutorado)instituição:

Campo de atuação:

Questões

1. O que você considera importante que as pessoas saibam sobre "água"?

2. Você considera importante a abordagem do tema água na disciplina de química no ensino médio? Explique.

3. Em sua opinião que conhecimentos os professores de química do ensino médio deveriam ter para tratar da problemática da água?

4.Quais são as atitudes, valores e comportamentos que os professores podem abordar no ensino de química utilizando o tema água? Explique.

5. Quais são as visões ambientais que os professores podem abordar no ensino de química utilizando o tema água? 


\section{Anexo 2. Questionário do pesquisador: Ensino de Química (EQ).}

Nome: Telefone: Endereço eletrônico:

Graduação:(Curso )instituição:

Pós- Graduação(Mestrado e Doutorado)instituição:

Campo de atuação:

Questões

1. Para você, qual é a importância de tratar no ensino médio a temática da água?

2. Aponte os assuntos (temas) e conceitos que você considera importantes e que deveriam ser abordados na temática da água no ensino de química. Por favor, aponte o grau de importância do tratamento desses assuntos e conceitos, utilizando a seguinte escala:

\begin{tabular}{|c|c|c|}
\hline Pouco & Médio & Muito \\
\hline 1 & 2 & 3 \\
\hline \multicolumn{2}{|c|}{ Assuntos(temas) } & $\begin{array}{l}\text { Grau de } \\
\text { importância }\end{array}$ \\
\hline & \\
\hline Conceitos & \\
\hline \multicolumn{2}{|c|}{} \\
\hline
\end{tabular}

3. Sobre a temática da água no ensino médio, faça outros comentários que você considera importante. 


\section{Anexo 3. Autorização dos especialistas.}

São Paulo.................................. de 2007.

Eu autorizo a aluna Daniele Torralbo do curso de Pós-Graduação em Ensino de Ciências Química da USP a divulgar em sua dissertação as respostas do questionário, preservando minha identidade.

Ciente:Prof.(a)

Coloque o seu nome completo. 


\section{Anexo 4. Questionário do professor}

Nome:

Telefone:

Escola:

Tempo que leciona:

Série:

Formação:

Email:

Questões

1 - Você aborda o tema água?

2- Como você aborda?

3-Dos conteúdos relacionados a seguir, aponte a série.

\begin{tabular}{|l|l|}
\hline Conteúdos & Séries \\
\hline Recurso & \\
\hline Qualidade da água & \\
\hline Contaminação água & \\
\hline Tratamento da & \\
\hline Distribuição & \\
\hline Política & \\
\hline Ciclo da água & \\
\hline Saúde & \\
\hline Usos & \\
\hline Clima & \\
\hline Vida & \\
\hline Fotossíntese & \\
\hline Formação de nuvens & \\
\hline
\end{tabular}

